Florida International University FIU Digital Commons

FIU Electronic Theses and Dissertations

University Graduate School

$3-25-2016$

\title{
A History of the United States Caribbean Defense Command (1941-1947)
}

Cesar A. Vasquez

Florida International University, cvasq006@fiu.edu

DOI: $10.25148 /$ etd.FIDC000266

Follow this and additional works at: https://digitalcommons.fiu.edu/etd

Part of the Diplomatic History Commons, Latin American History Commons, Military History Commons, Political History Commons, and the United States History Commons

\section{Recommended Citation}

Vasquez, Cesar A., "A History of the United States Caribbean Defense Command (1941-1947)" (2016). FIU Electronic Theses and Dissertations. 2458.

https://digitalcommons.fiu.edu/etd/2458

This work is brought to you for free and open access by the University Graduate School at FIU Digital Commons. It has been accepted for inclusion in FIU Electronic Theses and Dissertations by an authorized administrator of FIU Digital Commons. For more information, please contact dcc@fiu.edu. 


\title{
FLORIDA INTERNATIONAL UNIVERSITY
}

Miami, Florida

\section{A HISTORY OF THE UNITED STATES CARIBBEAN DEFENSE COMMAND}

(1941-1947)

\author{
A dissertation submitted in partial fulfillment of the \\ requirements for the degree of \\ DOCTOR OF PHILOSOPHY
}

in

HISTORY

by

Cesar A. Vasquez 
To: Dean John F. Stack

School of International and Public Affairs

This dissertation, written by Cesar A. Vasquez, and entitled A History of the United States Caribbean Defense Command (1941-1947), having been approved in respect to style and intellectual content, is referred to you for judgment.

We have read this dissertation and recommend that it be approved.

Victor Uribe

April Merleaux

Eduardo Gamarra

Kenneth Lipartito, Major Professor

Date of Defense: March 25, 2016

The dissertation of Cesar A. Vasquez is approved.

Dean John F. Stack

School of International and Public Affairs

Andrés G. Gil

Vice President for Research and Economic Development and Dean of the University Graduate School

Florida International University, 2016 
(C) Copyright 2016 by Cesar A. Vasquez

All rights reserved. 


\section{DEDICATION}

This dissertation is dedicated to the students, faculty, and staff of the FIU History Department. They are parts of a whole, and have created a unique and valuable body that I am proud to be a part of. I have found my time at FIU to be both challenging and rewarding. It has allowed me not only to understand what it is to be a historian, but also to become a better historian in the process. 


\section{ACKNOWLEDGMENTS}

I wish to thank the members of my committees both past and present for their support, patience, and understanding, which was essential to my ability to complete this dissertation. Dr. Eduardo Gamarra, who I met as an undergraduate teenager almost twenty-five years ago, has been a great example to me over the years. I was thankful for his acquiescence to be on my committee as well as his input and advice throughout this process. Dr. Victor Uribe, whose classes greatly helped in improving my craft, was equally a great source of comfort and advice when I initially stumbled in my pursuit of this degree. In her relatively short time on my committee, Dr. April Merleaux was not only key in my ability to finish on time, but also gave me valuable advice and guidance which helped me to complete my research. Professors Chantalle Verna, Darden Pyron, and Noble David Cook who all served on my comprehensive exams committee were also instrumental in allowing me to finish, and I thank all of them for their time and all their efforts on my behalf. I would especially like to thank my major professor, Dr. Kenneth Lipartito. From the time Dr. Lipartito first joined my dissertation committee, his guidance and support were essential to my writing and progress. His sage advice and encouragement helped me along the process, and made me believe in my ability to succeed.

I also wish to thank all the family and friends who supported me through my degree program. My brother John Ahumada was of great help in spurring me on and giving me encouragement at times when I felt like giving up. Likewise my good friend

Dr. Roberto Pacheco, who entered the Ph.D. program with me and beat me out by about a 
year, helped me get over the last difficult hurdles. Finally, I would like to thank Dr. Bradley Coleman, Command Historian, U.S. Southern Command (2007-2012) who hired me as a historian at SOUTHCOM and first introduced me to the history of the CDC. He gave me the means to re-enter the Ph.D. program following a leave of absence that had threatened to become permanent, and then helped and encouraged me along the way. Without the contributions of all these individuals, I would not have been able to complete this work. I am forever in their debt. 
ABSTRACT OF THE DISSERTATION

\section{A HISTORY OF THE UNITED STATES CARIBBEAN DEFENSE COMMAND}

$(1941-1947)$

by

Cesar A. Vasquez

Florida International University, 2016

Miami, Florida

Professor Kenneth Lipartito, Major Professor

The United States Military is currently organized along the lines of regional combatant commands (COCOMs). Each COCOM is responsible for all U.S. military activity in their designated area of responsibility (AOR). They also deal with diplomatic issues of a wide variety with the countries within their respective AORs. Among these COCOMs, Southern Command (SOUTHCOM), whose AOR encompasses all of Central and South America (less Mexico) and the Caribbean, is one of the smallest in terms of size and budget, but has the longest history of activity among the COCOMs as it is the successor to the first joint command, the United States Caribbean Defense Command (CDC 1941-1947).

Existing from 1941 to 1947, the CDC was tasked with protecting the Panama Canal, the Canal Zone, and all its access points as well as defending the region from Axis aggression and setting up a series of U.S. bases throughout the Caribbean from which to project U.S. military power after World War II. Throughout its short history, however, 
the CDC was plagued with the same types of resource scarcity that its successor commands would later experience. Early successes, as well as the progress of the war saw to it that the original mission of the Command was quickly rendered moot. Ironically, it was partially the success of the U.S. war effort that kept the CDC from ever reaching its full potential. Nevertheless, the CDC evolved into something different than had originally been envisioned. In the end, it became the model that other COCOMs would follow after November 1947 when the system of regional combatant commands was formally established. Although some research has been conducted into the history of these commands, this dissertation is the first academic attempt to chronicle the history of the United States Caribbean Defense Command.

Research into this topic involved combing through the Archives of the United States Southern Command in its offices in Miami, Florida (SOUTHCOM Archives), as well as the CDC archives in Record Group 548 in the U.S. National Archives II in Suitland, Maryland. Secondary sources as well as references regarding treaties and international agreements were also consulted as necessary. 


\section{TABLE OF CONTENTS}

CHAPTER

PAGE

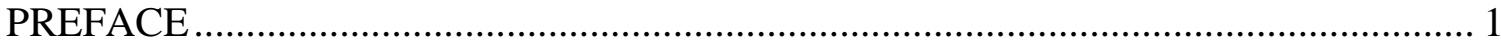

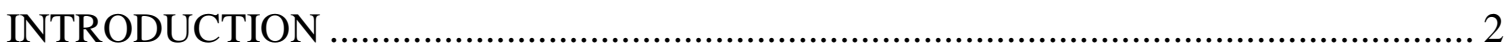

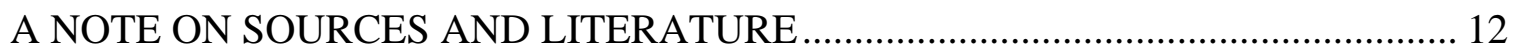

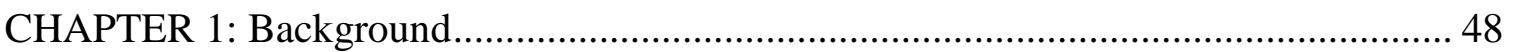

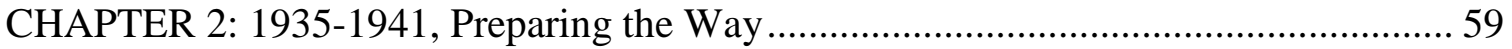

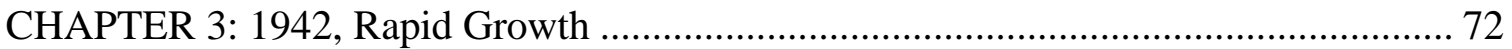

CHAPTER 4: 1943, Peaking and Reorganization ................................................... 97

CHAPTER 5: 1944-1947, Redefinition and Rapid Downsizing ................................. 120

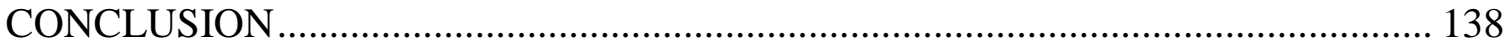

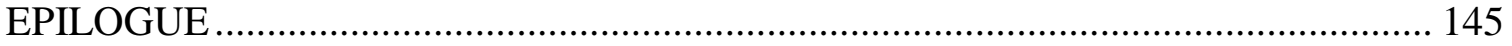

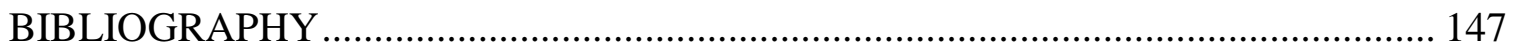

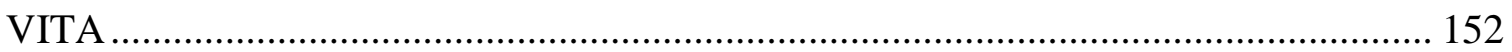




\section{LIST OF FIGURES}

FIGURE

PAGE

FIGURE 1: The Miraflores Locks under Construction in 1912 .................................... 7

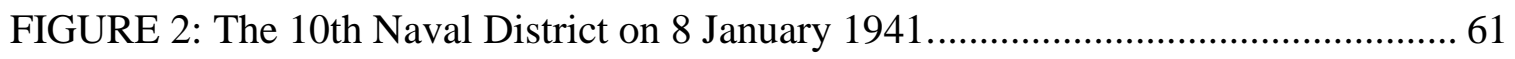

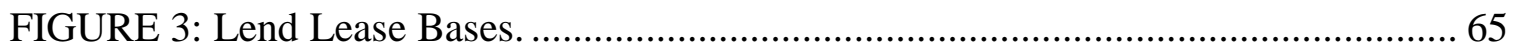

FIGURE 4: The Caribbean Naval Coastal Frontier on 1 July 1941.............................. 67

FIGURE 5: The Caribbean Sea Frontier, 19 April 1942 ............................................... 74

FIGURE 6: U.S. Personnel Manning Coastal Artillery............................................... 87

FIGURE 7: Black Troops in the Caribbean Region in 1942..................................... 116

FIGURE 8: Colombian Troops Manning a Machine Gun during Korean Conflict. ...... 140 


\section{PREFACE}

In late 2009, I accepted a position as a contracted historian at U.S. Southern Command under Command Historian Dr. Bradley Coleman. Having never had the opportunity to serve, this was my first real exposure to the military so to say it took some getting used to would be an understatement. As I grew more comfortable in my position and learned more about the functions of Southern Command, I began to understand the important role this command, as well as other regional combatant commands, plays in the U.S. military. The position also allowed me to finish my coursework, and when it came time to begin preparing for comprehensive exams and dissertation work, I found that my interests had shifted from southern history more toward U.S. relations with Latin America in line with the work I was doing at Southern Command.

While there, I became familiarized with both the history of the Command and its predecessors and with Record Group 548 of the U.S. National Archives which contains the bulk of the records of the Caribbean Defense Command. The relatively untapped wealth of knowledge contained in this record group would be enough to fill countless volumes, and I cannot possibly do it justice in a single dissertation. Nevertheless, the story of the Caribbean Defense Command is one that has been neglected for too long. The history of how the CDC became the prototype that later regional combatant commands would follow is one that deserves to be told as it was the first time a joint command of this nature had been attempted and had far reaching consequences in the way the U.S. military operates to this day. 


\section{INTRODUCTION}

The phrase "military efficiency" is normally understood to mean the ability to do something both quickly and with maximum effect in view of resources being utilized. Whether or not an unbiased observer of the United States' military would actually label its work as being done with "military efficiency" is up for debate. Like any human institution, the U.S. military is subject to its own flaws, foibles, and phases, and it has not always (or possibly ever) functioned or operated with what one would term "military efficiency.” Inter-service competition has always played a large part of the relationship between the services and this has not always been limited to simply the annual Army/Navy football game, but has also included competition among high-ranking officers over the allocation of limited resources.

Current United States military doctrine espouses the use of overwhelming force on an enemy, as well as the ability to conduct two major theater wars simultaneously, tasks that clearly call for military efficiency. ${ }^{1}$ However, the logistics of accomplishing these tasks are easy to overlook. For one, the United States military is not a singular unit. It consists of five different branches, all with their own different purposes, personalities, traditions, practices, and histories. The five branches of the U.S. military are the U.S. Army, U.S. Navy, U.S. Marine Corps, U.S. Air Force, and U.S. Coast Guard. Each of these is responsible for differing aspects of military activities. Confusingly, however, several of these responsibilities overlap. The U.S. Marine Corps, for instance, though

1. U.S. Department of Defense, Quadrennial Defense Review Report, Sept.30, 2001 (Washington DC: Dept. of Defense, 2001), 18, http://purl.access.gpo.gov/GPO/LPS18834. 
normally considered its own independent branch of the service, still administratively operates in some respects as a part of the U.S. Navy. Though the U.S. Air Force is normally thought of as composing the United States' air power, the U.S. Navy, Marine Corps, Army, and Coast Guard all have pilots and ample aviation assets. Many of the best fighter pilots in the military are in fact Navy pilots based on aircraft carriers. Moreover, while the term "sailor" conjures the image of ship-based personnel, the U.S. Navy seals, such as those involved in the 2011 raid that killed Osama Bin Laden, were Navy personnel, meaning they could technically be called "sailors."

Further confusing matters is that although every service has its own Chief of Staff and administration, the administration of the U.S. military as a whole is currently separated into several regionally based combatant commands. People are used to hearing the term "Central Command,” "Northern Command,” or “European Command,” but few actually understand the meaning of these terms, nor could they conceive of the structures these commands encompass without having it described to them in detail. Each of these regional combatant commands oversees all military assets assigned to a particular region of the world. For instance, Army and Marine units serving in Europe are under the command of United States European Command, headquartered in Stuttgart, Germany. All military units assigned to the Middle East report to United States Central Command in Tampa, Florida. Defense of the continental United States is handled by forces under U.S. Northern Command, headquartered in Colorado Springs, Colorado, while all military units assigned to Central America (less Mexico), South America, and the Caribbean report to United States Southern Command headquartered in Miami, Florida. 
Although many are familiar with the concept of an army base, the headquarters of these combatant commands operate under a different concept altogether. Combatant command headquarters normally house personnel of all five military groups. Their staff consists of a mixture of personnel from all branches of the military, many with different training and procedures. Since the 2000s when the separate branches of the service began differentiating their combat fatigues from the standard woodland camouflage battle dress uniform that had been used since the 1980s, it has also meant that Combatant Commands have included service members wearing uniforms with a plethora of differing colors and camouflage patterns, along with any civilians that may be employed there, and even partner nation military personnel assigned to liaison duty. These are truly unique headquarters.

Aside from the superficial, the structure of the work these commands do is also unique. They are not tasked with any singular military mission, such as defending a position or engaging an enemy. The work they do encompasses what is presently termed a "whole of government approach." That is, these commands are at the forefront of bringing all the resources of the U.S. government, not simply its military, to bear on their mission. In practice, this means that these combatant commands include elements of the U.S. Department of State, as well as other agencies ranging in scope from the Federal Emergency Management Agency (FEMA) to the United States Agency for International Development (USAID). This allows them to oversee activities as varied as disaster relief, school construction, assisting partner nations with water reclamation, and aiding U.S. embassies in the region in cases of political turmoil. In the case of United States Southern Command, the Military Deputy Commander, the second highest ranking 
military officer, has a civilian counterpart. This counterpart is called the Civilian Deputy to the Commander (for reasons of military discipline, namely that as a civilian he cannot issue military orders he cannot be called a deputy commander). This Civilian Deputy also serves as the senior foreign policy advisor to the Commander, and often represents the Command abroad. This position is an ambassadorial level assignment in the United States Foreign Service, and is often filled by ambassadors coming from a previous assignment in the Southern Command AOR.

Structurally, all combatant commands have different missions based on the nature of the region they are assigned to, thus U.S. Central Command spent the beginning of the twenty-first century heavily involved in war fighting in the Middle East and commanded a much greater part of the military budget than it had the previous century. U.S. European Command had largely been at the forefront of the Cold War until its end in 1991, at which point the Command had to deal with the splintering of the Soviet Union and increasing strife in former Soviet satellite countries. U.S. Pacific Command is largely dependent on naval power and assets and covers a geographically larger area than any of the others, but is typically more likely to participate in humanitarian assistance/disaster relief activities than war fighting. Africa Command which is the newest of the COCOMs is still rather small and is not physically located on the continent it serves, but still has to deal with a highly unstable region. The instability of the African continent makes their work doubly difficult.

The United States Southern Command meanwhile is tasked with running and maintaining United States military presence throughout an AOR which has been 
generally peaceful for over a century. Though there have been border skirmishes and small scale "wars" fought throughout the SOUTHCOM AOR, there have been no major invasions which would drastically alter the AOR's map. It is surprising then that U.S. Southern Command can trace its existence back farther than any of the other regional combatant commands of the U.S. military establishment. U.S. Southern Command came into existence in 1963. For most of its existence (as of this writing) it was headquartered in Quarry Heights, Panama Canal Zone and only moved to its current location of Miami, Florida in 1997 in anticipation of the handover of the Panama Canal and Canal Zone back to Panama at the end of 1999.

From 1947 to 1963, SOUTHCOM’s predecessor was United States Caribbean Command. Caribbean Command was initially tasked with responsibilities over the waterways and access points to the Panama Canal as well as all military forces throughout the region. Due partly to interagency competition and partly to international politics, Caribbean Command's AOR was steadily reduced until 1963 by which point it did not have any actual role in the Caribbean at all. Thus, the re-organization and renaming from Caribbean Command to Southern Command was as much to avoid confusion as it was to deal with administrative and tactical issues. From 1941 to 1947, the predecessor to both of these was the United States Caribbean Defense Command (CDC). The CDC was a prototype combined command tasked with protecting the Panama Canal and its access points as well as dealing with possible Axis threats within the region. Its existence was precipitated by World War II. The need for such a combined combatant command was dictated by the presence of the Panama Canal and Canal Zone. 


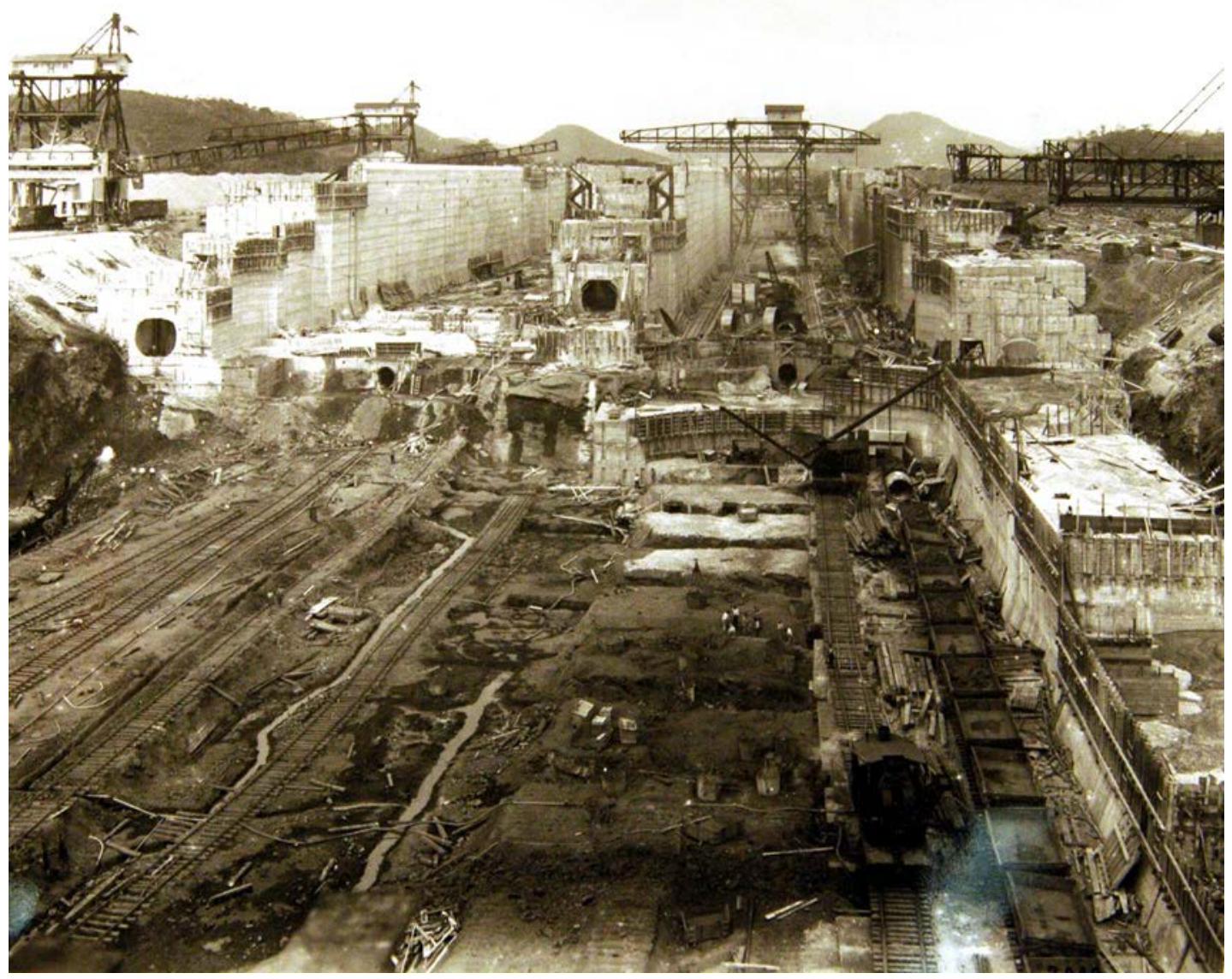

FIGURE 1: The Miraflores Locks under Construction in 1912.

Source: Pictorial Archives of United States Southern Command, SOUTHCOM Archives.

The Panama Canal is both a marvel of engineering and a great logistical challenge to operate. It operates via a series of large locks which were carved into the surrounding isthmus via a long and arduous process (see Figure 1). These locks are intricate mechanisms and vulnerable to mechanical issues and possible sabotage. The Canal has been at times considered a military and a commercial asset. It is immobile, making it inherently vulnerable to attack, and was and remains approachable via two oceans at a time when the United States was at war with two very aggressive nations both of which commanded ample naval assets. The Canal Zone was an exclave of American personnel in a location that was both remote from the United States and not quickly reachable with 
the technology of the time. Moreover, governmental instability in the region always threatened to leave the Canal in close proximity to potentially hostile nations.

Another part of the mission of the CDC was that of setting up a series of bases which would serve to project U.S. power in the region in the postwar period. The fact that this never materialized led some to postulate that the CDC had at least partially failed in its mission, but such assessment does not take into consideration the reasons behind such failure. The CDC was established in order to help forward the war effort, but the war never really came to the region. Many of the larger fears that had been posited about German U-Boats, Japanese warships, Axis infiltrators, or fifth column saboteurs either never materialized or were dealt with quickly at the beginning of the war effort.

As it turned out, the Caribbean Defense Command had less military significance during World War II than military leaders had originally thought it would. Axis aggression against the region having been effectively dealt with early on after the U.S. entry into the war, meant that no major attacks against the Panama Canal or Canal Zone were ever successfully carried out. Furthermore, the U.S. contingency plans for using and improving Panamanian railroads for moving supplies from the Atlantic to the Pacific in case of emergency were assessed to be sufficient to supplant the Canal altogether should the latter become completely inoperable. Over ten thousand American military vessels eventually passed through the canal during World War II, but the railroads along the isthmus by themselves would have been sufficient to handle all the shipping just as 
well as the Canal had, though at an admittedly higher price. In retrospect, this rendered the Canal less of a strategic asset than a symbolic, diplomatic, and economic one. ${ }^{2}$

As the tide of war began to turn, the Caribbean Defense Command saw itself being increasingly marginalized militarily, with resources and personnel reduced. By this time though, the CDC had begun to operate on other fronts such as diplomacy and training which saw increased success. Indeed, the gains that the Caribbean Defense Command continued to achieve more than made up for the lack of action in the region. Inter-American military cooperation reached an all-time high, with almost every country in the region eventually declaring war against the Axis. Military training and cooperation undertaken by the CDC increased the capabilities of allied militaries to defend themselves, lessening the need for direct U.S. intervention and acting as a force multiplier.

As such, with the war winding down, the focus of the Caribbean Defense Command began to shift from the security and defense of the Panama Canal and the AOR from Axis aggression, to what could be more accurately called inter-American cooperation. In November of 1944, the command began to establish additional training resources to assist the efforts of the American republics to "mold their individual military

2. Noel Maurer and Carlos Yu, The Big Ditch: How America Took, Built, Ran, and Ultimately Gave Away the Panama Canal (Princeton, NJ: Princeton University Press, 2011), 125. 
groups into well-functioning and efficient organizations patterned after the general principles of the United States Army. ${ }^{3}$,

Finally, the end of the war left the command without its defining purpose, making it inevitable that it would have to adapt to fill a new role or cease to exist altogether. Although the Caribbean Defense Command only outlasted the war by two years, its greatest accomplishment could be said to have been that it survived the war at all. The existence of the CDC proved that it was possible to run a regionally based joint combatant command outside of the territorial United States and have it contribute to a major war effort. The activities of the Command toward the end of the war, moreover, shifted dramatically to the role of diplomacy which would prove to be far more necessary to a postwar world heading into the Cold War than would a series of Caribbean bases. As such, the Caribbean Defense Command actually anticipated the roles that such COCOMs would play in the future.

Additionally, the presence of the Caribbean Defense Command helped the United States in its dealings with its neighbors by providing a centralized authority within close proximity to the South American continent which could communicate quickly with decision makers in Washington D.C. In the end, the Caribbean Defense Command evolved into more than it was originally intended to be, and set a precedent for how such combined combatant commands can operate and what they could accomplish. Although it could be argued the initial goals of the Caribbean Defense Command were never fully

3. Training Memorandum Number 1, Training Directive Training Year 1945. Headquarters, Caribbean Defense Command, Office of the Commanding General, Nov. 1, 1944, Record Group 548, U.S National Archives II, Suitland, Maryland, Entry 5, Box 1 (hereafter cited as RG 548). 
achieved, leading some to consider the Command a partial failure, the fact that the U.S. military is today divided among regional commands in the model first established by the Caribbean Defense Command suggests that if it was a failure, it was a very successful failure at worst.

The following chapter will deal with the sources used in writing this dissertation as well as a review of pertinent literature that was consulted. Subsequent chapters will follow in a generally chronological order. Chapter one briefly provides some background information on U.S. relations with the region. Chapter two discusses the years immediately leading to the creation of the CDC. Chapter three documents the CDC's first full year of existence and the rapid growth the Command experienced. Chapter four examines 1943, the year which turned the tide in activity for the command and began the trend in downsizing that would continue for the rest of the command's history. Chapter five focuses on the last years of the command when downsizing caused a redefinition of the Command's goals and missions in a world at the beginning of the Cold War. The conclusion then explains why the history of the CDC is important to understanding both the progress of the Cold War in the region and in understanding the present organization of the U.S. military worldwide. 


\section{A NOTE ON SOURCES AND LITERATURE}

As for primary sources, a great deal of the documents cited here will be documents from the U.S. National Archives collections on the military in the region. Many of these were pulled from the existing collection of the United States Southern Command History Office which made an effort to retrieve these from the National Archives starting in 2008. The use of these documents carries with it both certain benefits and some limitations. For example, during the existence of Caribbean Defense Command, several reports were generated attempting to document the functions of the Command. These reports were often titled as histories, although they were being written in real time during the existence of the command with no hindsight, and nothing in the way of literature review. In reality these "histories" were more akin to after action administrative reports. They were mostly written by uniformed personnel, and often contained ample references to internal military orders, but offer little if any analysis. Many of these can currently be found in the CDC archives in Record Group 548.

Several of these reports, as well as other similarly located primary documents were used in the preparation of this dissertation. Three of these in particular, the "AntiSubmarine Activities in the CDC," and the similarly titled "History of the Caribbean Defense Command," and "History of the CDC," were particularly useful early on in mapping out a rough outline for the first part of the narrative, though the fact that they were mostly written while the CDC was still in operation made them less useful in analyzing the subject. Unsurprisingly, little or no attempt was made by the authors of these reports to place them in context of the academic writings of the time, as they were 
intended for internal military audiences only. For the most part, the personnel preparing these were interested in celebrating the work of the Command and that of the U.S. military and perhaps pointing out best practices to increase military efficiency. These documents are, however, good points of insight into the military mentality and biases of the time. One in particular, the "History of the CDC," contained a section which betrayed a very cavalier attitude toward racial discrimination on the part of the author which will be analyzed later on. Care has been taken to analyze these primary documents in an objective manner. Wherever possible, the documents they cite have been retrieved and scrutinized for further clarity.

Additionally, some internal U.S. Southern Command reports, a number of which were written by the author of this dissertation while a historian there, have also been used for reference. Although internal SOUTHCOM documents sometimes contain secret information, no such report was used in preparing this dissertation. All documents cited here are unclassified in nature and available via Freedom of Information Act requests from the U.S. Southern Command History or Public Affairs offices. One of these documents, titled, “Crisis, Transformation and Renewal, Historical Review of the Tenure of General Douglas Fraser (USAF) As Commander, United States Southern Command, June 2009-November 2012,” contains secret sections which were not accessible to the author so all portions cited from this report contain only unclassified information.

As for the historiography, much has been written on the history of the United States' relation with what encompassed the CDC's Area of Responsibility, though interestingly the works on U.S. relations with mainland South America have often been 
separated from those on relations with the Caribbean. Like any other subject, this relationship has undergone several phases which were influenced by both developments within the United States and internationally. In particular, the drug trade and political factors have contributed to a noticeable shift in the way the history from the beginning of the twentieth century to the end of the Cold War has been approached. Not surprisingly, early American historians used the opportunity of documenting this relationship to try to celebrate American exceptionalism in the first part of the century. This was aided in particular by the United States’ successful construction of the Panama Canal even though the United States' actions in creating the canal were probably among the most questionable actions it took toward the region and caused bad feelings which took decades to dissipate. This particular episode is representative of several of policy shifts that characterized these relationships.

Early academic attention to mainland South America was sparse at best. Latin America as a whole had escaped the scrutiny by many American scholars that had been directed at Europe and to some degree Asia. United States’ relations with Latin America as a whole were initially seen through a largely United States-centric point of view. The most influential work defining this period was Henry Flag Bemis’ The Latin American Policy of the United States: An Historical Analysis (1943). ${ }^{4}$ Bemis’ primary goal seemed to be the celebration of American exceptionalism. His analysis, which came to be called the "Western hemisphere idea," was very much a product of its time and dealt heavily

4. Samuel Flagg Bemis, The Latin American Policy of the United States (New York: Harcourt, Brace and Co., 1943). 
with issues of security (it was written during World War II). Overall, the analysis was very accepting of enforced United States nationalism and rejoiced at solidarity against the axis threat that was being demonstrated by the United States and its Latin allies. It praised the "Good Neighbor Policy" and saw "imperialism” as a false claim or where it did exist, as being largely benign at worst. This analysis was later identified as the “liberal” approach by Abraham Lowenthal in his 1973 article, “United States Policy Toward Latin America: 'Liberal,' 'Radical,' and 'Bureaucratic.'” Regardless of the nomenclature however, the essential analysis saw relations between the United States and its southern neighbors as predicated on "an essential compatibility of interests” derived from a shared experience of republican rebellion. ${ }^{5}$

Bemis argued that the Monroe Doctrine was mainly a defensive move born out of legitimate American fears of European powers returning to take away the newly gained independence of the Latin American republics_-and then that of the United States itself. He treated the U.S. expansion following the doctrine of manifest density as benign saying that “There was no thought other than peaceful expansion.” He further characterized Theodore Roosevelt's policy of the "big stick" (the Roosevelt Corollary) as benevolent and "a bit of a necessity” at the time. Tellingly, Bemis was particularly reluctant to use the term "imperialism” except to explain that it is what he was referring to when using his preferred term, “new manifest destiny.” He then went on to outline exactly why any

5. Abraham F. Lowenthal, "United States Policy toward Latin America: Liberal, Radical, and Bureaucratic Perspectives,” Latin American Research Review 8 (Fall 1973): 3-25 
expansive American attitude was justified in light of actual threats both to itself and its neighbors.

Bemis’ positive, and some would say shallow analysis, was short lived. The 1959 Cuban Revolution increased United States governmental funding and scholarly attention to the region and opened up a new front in the Cold War. For the first time, countries of the Western Hemisphere seemed at risk of becoming Soviet satellites, and the region’s rich and so far untapped history became an increasingly popular subject for graduate students and scholars. The field quickly began to be filled with a differing analysis which saw Bemis’ pro-American views as naïve and downright cringe inducing in their simplicity. The ensuing years saw a great deal of scholarship following what Abraham Lowenthal termed the "radical" approach, but which others have labeled as simply

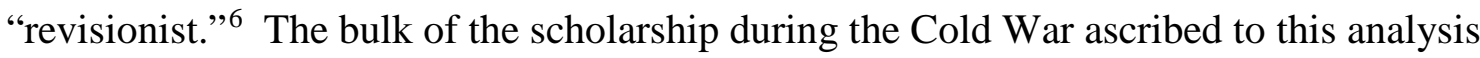
was predicated on the idea that the United States was committing economic imperialism toward Latin America as a whole and was pursuing its own Cold War goals rather than true partnerships with the region. By the end of the Cold War, most historians had largely bought into the radical perspective. It should be noted that the third perspective which Lowenthal identified; the "bureaucratic" perspective dealt with looking at United States decision making from a structural perspective of how policy was derived by different actors without looking deeply at the underwriting ideologies. According to Mark T. Gilderhus in his article, “An Emerging Synthesis? US.-Latin American Relations since the Second World War,” this particular perspective has been popular among social

6. Lowenthal, "United States Policy toward Latin America,” 3-25. 
scientists, but has not generally appealed to historians, especially those espousing the radical perspective. $^{7}$

Key early scholars writing in the radical/revisionist school included William Appleman Williams and Walter LaFeber. In his The New Empire: An Interpretation of American Expansion, 1860-1898 (1963), LaFeber set out to prove that the SpanishAmerican War and the American acquisition of a colonial and informal empire that followed it were not a "great aberration," as Bemis had labeled the phenomenon. Rather, LaFeber maintained that American policy at the turn of the century was part of and the result of three decades of evolution in American political and business thought which moved Americans away from an isolationist mindset to a more commercial one following the closing of the frontier. ${ }^{8}$ Likewise, David Green's The Containment of Latin America (1971) was a radical/revisionist critique that saw international organizations as part of the United States’ approach to establish economic dominance over the region. ${ }^{9}$ There was also a subtle Marxist emphasis to this analysis, as it saw these policies as the requirements of capitalist enterprises. R. A. Humphries in Latin America and the Second World War was interested in showing how the United States’ Cold War strategy eclipsed

7. Mark T. Gilderhus, "An Emerging Synthesis? US-Latin American Relations since the Second World War,” Diplomatic History 16, (Summer 1992): 429-452.

8. Walter LaFeber, The New Empire: An Interpretation of American Expansion, 1860-1898 (Ithaca, NY: Cornell University Press, 1963).

9. David Green, The Containment of Latin America: A History of the Myths and Realities of the Good Neighbor Policy (Chicago: Quadrangle Books, 1971). 
its wartime friendship with South America. ${ }^{10}$ Likewise, Frederick Pike’s The United States and the Andean Republics looked at the relationship between the United States and three Andean nations and claimed there was a basic disconnect between the United States' perception of the region and the way the region really operates. ${ }^{11}$ The United States, according to Pike, believes in individual initiative while the countries of the Andean region have very closed patron-client systems. Thus, he characterized the relationship between the United States and these nations not as an economic struggle or even a political one, but as one of actual differing ideologies.

Along the same lines, Stephen G. Rabe’s Eisenhower and Latin America: The Foreign Policy of Anticommunism (1988) characterized United States policies toward the region as being driven by the fear of Soviet encroachment and a fierce anti-communist spirit. ${ }^{12}$ Rabe argued that the Eisenhower administration began by supporting highlyflawed regimes in the region in the hopes of building anti-Soviet alliances. It was not until backlash from the Latin American populations (e.g., over Vice President Nixon’s disastrous visit to Peru in 1958) challenged the Eisenhower administration's belief that they were winning over the region that their approach began to shift to a more cooperative one. The 1959 Cuban Revolution then shocked the United States further into attempting to actually stem the conditions which would lead to revolution, but also

10. R.A. Humphreys, Latin America and the Second World War (London: University of London Press, 1981).

11. Fredrick B. Pike, 1977. The United States and the Andean Republics: Peru, Bolivia, and Ecuador (Cambridge, MA: Harvard University Press, 1977).

12. Stephen G. Rabe, Eisenhower and Latin America: The Foreign Policy of Anticommunism (Chapel Hill, NC: University of North Carolina Press, 1988). 
increased the amount of covert activity which would later lead to added complications between the United States and Latin American partners. Two additional volumes on diplomatic history which employ this perspective when dealing with the relationship between the United States and the region are Robert D. Schulzinger's Henry Kissinger: Doctor of Diplomacy (1989), and Seymour Hersh's The Price of Power: Kissinger in the Nixon White House (1983). ${ }^{13}$ Additionally, Abraham F. Lowenthal's Partners in Conflict: The United States and Latin America in the 1990s (1990) examines the changes in a Latin America that has become more urban, increasingly middle class and industrial, and that is now less subject to coercion form the United States. ${ }^{14}$

Despite taking a putatively more pro-Latin American perspective, many of the works adhering to the radical/revisionist perspective still continued to look at the issue from the point of view of the United States. Rabe's account, for instance, which is critical of United States motives, nevertheless is quite United States-centric and covers little ground with respect to the motivations of the Latin American countries themselves. He concludes that anti-communism was an obsession that caused mistakes or misperceptions, but that the Eisenhower policy was still coherent though ultimately unsuccessful in making the region a more engaged partner. Rabe paid little attention to what role race may have had in defining the relationships in the region even though there

13. Robert D. Schulzinger, Henry Kissinger: Doctor of Diplomacy (New York: Columbia University Press, 1989); Seymour Hersh, The Price of Power: Kissinger in the Nixon White House (New York: Summit Books, 1983).

14. Abraham F. Lowenthal, Partners in Conflict: The United States and Latin America (Baltimore, MD: Johns Hopkins University Press, 1987). 
are hints throughout that this was a factor. In the late 1980s-1990s as the Cold War was coming to an end, and the Andean nations began taking a larger role in the war on drugs, racial aspects came to be increasingly picked up by scholars, and Rabe’s model began to wane.

Over the past twenty years, scholars have realized that too little attention has been paid to Latin American countries themselves as well as to sources or agency. Recent work has tried to strike a balance by acknowledging the enormous impact of the United States while trying not to ignore the role of Latin America itself in shaping its own history. Historians such as Lester Langley have been looking at Latin American sources and cultural approaches to write more complex histories dealing with both American and Latin American politics, social issues, and even race. ${ }^{15}$ Of note, in this group is Lars Schoultz’ Beneath the United States: A History of United States Policy Toward Latin America, -ostensibly a diplomatic history-which looks at the relationship between the United States and Latin America. ${ }^{16}$ In Schoultz' narrative, the more powerful United States always tends to look down on and misunderstand its weaker partners. Inherent in Schoultz' argument is the idea of racism in so much that it is Latin America’s “Latin” character that causes the United States to look down on them. Schoultz effectively uses various sources such as diplomatic dispatches and correspondences to prove a greater

15. Lester D. Langley, The Americas in the Age of Revolution, 1750-1850 (New Haven, CT: Yale University Press, 1996.

16. Lars Schoultz, Beneath the United States: A History of United States Policy Toward Latin America (Cambridge, MA: Harvard University Press, 1998). 
point that much of the United States' attitude toward Latin America has been based on the assumption that Latin Americans are "inferior."

Aside from the end of the Cold War, the anniversary of Columbus' discovery of the New World also affected scholarship by inspiring increased interest in how the age of discovery had affected the development of the region, and further how the United States has interacted with the rest of the Americas. The University of Georgia (UGA) underwrote an entire book series on United States relations with Latin America beginning with Lester Langley's, America and the Americas: The United States in the Western Hemisphere (1989). ${ }^{17}$ This anniversary and the attention it drew also inspired other works which have looked at several of the same countries already included in the series, thereby adding to the richness of available literature on the region. The UGA series, which was spread out over more than a decade, contributed greatly to the subject of United States relations with the Americas as a whole. Aside from taking a good look at the subject at hand, these are a good starting point for scholars interested in the field though in some occasions developments in the region have moved at such a fast pace that some of the entries are no longer as relevant as they once were. Interestingly, many of the UGA series entries have ascribed to Pike's theory of differing interests and goals as being behind the conflicts between the United States and these countries.

William Sater's Chile and the United States: Empires in Conflict (1990) was the first of these books to deal with one of the Andean nations and claims that like the United

17. Lester D. Langley, America and the Americas: The United States in the Western Hemisphere (Athens, GA: University of Georgia Press, 1989). 
States, Chile's attitudes toward its neighbors were fueled by a belief in its own racial and cultural superiority. ${ }^{18}$ European immigration into Chile had left it with a distinctly European-looking population and characteristics which were unmatched in the continent until Argentina surpassed it in this respect. Sater then inserted race into his analysis in a degree and fashion that none of the others writing on Andean countries could have done. Interestingly, he carefully threads the needle when dealing with the United States involvement in the overthrow of Salvador Allende—a traditional sore spot in United States-Chile relations by admitting that the United States was rather more involved than it let on, but not particularly in any decisive way. This is actually a point of contention among some scholars. The idea that the United States was heavily involved in the overthrow of Allende is a recurring theme among some historians of the region. Max Paul Friedman in his article "Retiring Puppets, Bringing Latin America Back in: Recent Scholarship on United States-Latin American Relations,” states as fact that the United States was behind the overthrow, though he does not go to any lengths to prove his point, simply assuming the reader will concur. ${ }^{19}$ Also, Paul Sigmund's The United States and Democracy in Chile, argues that although the United States' interest in Chile played a role in setting up the revolution, the United States was not directly responsible for the events. ${ }^{20}$ In fact, Sigmund ultimately argued that the United States was divided on its

18. William F. Sater, Chile and the United States: Empires in Conflict (Athens, GA: University of Georgia Press, 1990.

19. Max Paul Friedman, "Retiring Puppets, Bringing Latin America Back in: Recent Scholarship on United States-Latin American Relations,” Diplomatic History. 27.5 (Nov. 2003): pp 621-636.

20. Paul E. Sigmund, The United States and Democracy in Chile (Baltimore, MD: Johns Hopkins University Press, 1993). 
support for the military at the time, seeing the greatest United States influence in the high level of importance that the United States Alliance for Progress gave to agrarian reform, which ironically actually led to the election of Allende in the first place. Though Sigmund does allow that the United States did try to influence the election of 1970 to try to keep Allende from winning, he posits that this was done out of a legitimate fear that Allende's election would mark the end of free elections in Chile. Likewise, he does not argue that the United States was behind the coup against Allende, though he concedes that they clearly signaled that they would not oppose such an act, ironically echoing the events leading up to the secession of Panama from Colombia.

The next book in the UGA series was Stephen Randall's Colombia and the United States: Hegemony and Interdependence (1992) which was equally critical of the United States’ handling of the Panama secession as Bemis had been, but without attempting to make excuses for U.S. behavior. ${ }^{21}$ Unlike Bemis, Randall does not see this incident as a singular black mark in an otherwise spotless record which is now forgotten. Instead, Randall argues that the event continues to haunt the relationship between the two countries to this day. He further argues that Colombian-United States relations have been hindered greatly not only by competing interests but also by different cultures (once again hinting at Pike’s “basic disconnect”). Randall’s book is at a bit of a disadvantage here as it was one of the earlier entries into this series and was written at a time when United States-Colombian relations were actually just beginning to improve rendering it

21. Stephen J. Randall, Colombia and the United States: Hegemony and Interdependence (Athens, GA: University of Georgia Press, 1992). 
somewhat dated by today’s standards. Without the benefit of hindsight, however, Randall could not document the very strong relationship that emerged between the United States and Colombia the way that Bradley Lynn Coleman later did in his more recent book Colombia and the United States: The Making of an Inter-American Alliance, 19391960. Coleman was able to document a more positive relationship between the two countries than Randall perhaps partly due to the fact that it was written after the relationship had already improved, allowing for some hindsight. ${ }^{22}$ Coleman argued that this relationship, despite having its ups and downs, had been remarkably positive throughout and particularly during the period he covers, making a big point about Colombia's participation in the Korean War. Coleman's thesis is overall one of largely positive if not consistent engagement with the region.

Randall's entry on Colombia was followed by Judith Ewell's, Venezuela and the United States: From Monroe's Hemisphere to Petroleum's Empire (1996) and Lawrence Clayton's, Peru and the United States: The Condor and the Eagle (1999), both of which documented similar ambiguous relationships normally based on a power differential. ${ }^{23}$ Neither of these two, however, ascribes directly to Pike's thesis the way Kenneth Duane Lehman does in his, Bolivia and the United States: A Limited Partnership (1999) where

22. Bradley Lynn Coleman, Colombia and the United States: The Making of an Inter-American Alliance, 1939-1960 (Kent, Ohio: Kent State University Press, 2008).

23. Judith Ewell, Venezuela and the United States: From Monroe's Hemisphere to Petroleum's Empire (Athens, GA: University of Georgia Press, 1996); Lawrence A. Clayton, Peru and the United States: The Condor and the Eagle (Athens, GA: University of Georgia Press, 1999). 
he juxtaposes Bolivian defeatist attitudes to the United States' very positive outlook. ${ }^{24}$ Perhaps demonstrating the relative lack of strategic importance to the United States that Ecuador has been perceived as having, a volume on Ecuador was slow to emerge. When it did come, Ronn Pineo's, Ecuador and the United States: Useful Strangers (2007) not surprisingly argued that lacking any particular appeal to the United States' interests, Ecuador was largely ignored by the United States throughout its history. ${ }^{25}$ The United States, however, was ever present in Ecuador's political calculations. Pineo does subscribe to Pike's thesis, but puts it in the context of simple lack of interest and characterizes the disconnect as resulting from one party having very modest and easily achievable interests on the part of the other which kept relations to a minimum (a fact made clear in the book's subtitle).

More recently, the rise of armed actors, narco-trafficking, and the United States' war on drugs directly after the end of the Cold War led to a re-examination of the power relationship between the United States and the Andean nations whose territory was the setting for much of the production of illegal narcotics. As early as 1993, David Bushnell in The Making of Modern Colombia: A Nation in Spite of Itself wrote that Colombia was "the least studied of the major Latin American countries and probably the least understood.”26 Bushnell's surprisingly upbeat book (given the subtitle) makes the

24. Kenneth Duane Lehman, Bolivia and the United States: A Limited Partnership (Athens, GA: University of Georgia Press, 1999).

25. Ronn F. Pineo, Ecuador and the United States: Useful Strangers (Athens, GA: University of Georgia Press, 2007).

26. David Bushnell, The Making of Modern Colombia a Nation in Spite of Itself (Berkeley, CA: University of California Press, 1993), vii. 
argument that the political situation in Colombia stabilized because the political system was able to successfully make participatory democracy work. Far from being the wreck flirting with becoming a failed state, as many described Colombia during the 1980s and 90s, Colombia, according to Bushnell was actually remarkably stable and peaceful. Notably, the United States plays a very small role in this account. Other books have looked at the subject itself rather than any specific country. Paul Gootenberg's Andean Cocaine: The Making of a Global Drug deals with the issue of cocaine as an Andean phenomenon, and not necessarily one that comes from any one country. ${ }^{27}$ Although he documents the contributions of several different countries in the history of cocaine, the end result is that the final conflict comes down to the United States versus the Andean world. It was after all in the United States where the drug first found its market, and it was the United States whose anti-drug policies became the backbone of their relationships with many of the coca producing Andean nations of South America.

The relationship between the United States and the countries of South America has therefore been both storied and long, and has passed through several different phases. Early works like that of Bemis were traditional pro-American narratives that celebrated the United States' national myth while minimizing any negative actions toward its neighbors. Later, the trend moved through several more negative views of American policies and goals, before retracting back to a more nuanced narrative in which the

27. Paul Gootenberg, Andean Cocaine: The Making of a Global Drug (Chapel Hill, NC: University of North Carolina Press, 2008). 
United States was simply a player, albeit a powerful one, in a larger world. This new narrative is not without its share of agency toward the nations of Latin America.

In the end, the relationship that the United States has had with South America is difficult to define simply because of the diversity of both parties. The United States has never been a single entity with a single mind that acts consistently with a given goal. Inasmuch as the United States has singular goals, they are largely generalized and usually the result of a consensus. Many times, there are various competing interests with diametrically opposed goals. The nations of South America also do not constitute a single entity either, but rather a community of nations with vastly different economies, resources, histories, and self-images. The difficulty in trying to reconcile all these into a consistent policy has often been the stumbling block in the United States' ability to deal with the region. The United States often finds itself at cross purposes with the nations of South America as their goals are not the same, nor are their very definitions of such seemingly universal words as "democracy.” The way that these have interacted constitutes a fascinating study in diplomatic relations.

The history of U.S. relations specifically with the Caribbean has taken a slightly different path, however, usually dealing more broadly with western influence than strictly an American one. This was partially because the region is distinct from mainland South America. It is more heterogeneous, and had to deal with European colonial powers for a much longer time than the continent did. The most common framework that has been used in analyzing the Caribbean has been the Braudelian Mediterranean model of world systems. This model posits that the Caribbean, like the Mediterranean, is a living entity 
onto itself, though dominated by a powerful hegemon (in the case of the Mediterranean this was Rome, in the case of the Caribbean this has been the United States). ${ }^{28}$ Although this comparison seems fairly straightforward, further scholarship has demonstrated that the model does not always hold. The Caribbean is significantly culturally different than the Mediterranean in ways that often defy easy classification. Although Braudel's model is useful, it does not take into consideration the fact that a large portion of South America is also part of the Caribbean, which has been influenced by its own shared history with Spain. In the end, there are structural weaknesses to this model which clearly call for a future reconsideration of how the Caribbean is seen, and point the way for future research.

First published in 1944 and then updated in 1966, Eric Williams’ Capitalism and Slavery was one of the earliest and most influential books on the subject and the region. It was in Williams' own words an attempt to, "place in historical perspective the relation between early capitalism in Europe, as exemplified by Great Britain, and the Negro slave trade and Negro slavery in the West Indies.” ${ }^{29}$ Williams saw the growth of the slave trade as natural extensions of the development of capitalism in Britain, and saw the end of the slave trade as the end result of Capitalist development. In Williams' analysis, the British humanitarian movement, long credited with ending slavery was actually only

28. Fernand Braudel, The Mediterranean and the Mediterranean World in the Age of Philip II (New York: Harper \& Row, 1972). The Mediterranean model has tended to go hand-in-hand with writings espousing dependency theory such as Fernando Henrique Cardoso, Dependency Revisited (Austin, TX: University of Texas Press, 1973).

29. Eric Williams, Capitalism and Slavery (New York: Capricorn Books, 1966), Xii. Williams' thesis also inspired Manuel Moreno Fraginal's, The Sugar Mill: The Socioeconomic Complex of Sugar in Cuba, 17601860 (New York: Monthly Review Press, 1976). 
another part of the society which had created the slave system to begin with. As such, this movement was motivated by economic factors as much as the slave trade itself had been. Not surprising for the time, Williams' book is at heart a Marxist analysis arguing that the end of slavery was predicated by the economics of the establishment of a capitalistic world system. He argued that by the final years of the slave trade, slaveholders had lost political power due to the inherent weaknesses of the slave system and were thus marginalized by laissez-faire advocates who disliked colonial monopolies. The decision to end the slave trade at first and later to do away with slavery altogether was an economic one seeking the expansion of capitalism. Though never universally accepted, Williams' study came to be seen as a pioneering work which requires citation whenever looking at Caribbean history of the period.

Following up on his own work at the height of the Cold War, Eric Williams wrote an extensive survey of the history of the region. In From Columbus to Castro: The History of the Caribbean, 1492-1969, he claimed that the very first expedition to the New World went forth with the knowledge that Africa could become “The white man's greatest and most plastic collaborator in the task of agrarian colonization.” 30 The monopoly which emerged was simply an extension of the pre-existing monopoly that existed in Europe at the time. This idea was later expanded by Franklin Knight when he pointed out that the very nature of the societies that first emerged in the Caribbean (and

30. Eric Williams. From Columbus to Castro: The History of the Caribbean, 1492-1969 (New York: Harper \& Row, 1971), 17. 
even North America) were in fact simply continuations of the societies that existed in Europe at the time. ${ }^{31}$

Looking at another aspect of the influence on the Caribbean, Alfred Crosby's The Columbian Exchange: Biological and Cultural Consequences of 1492 took a more naturalistic approach, arguing that the actual physical makeup of the New World was affected by the coming of European settlers. He began with an account of the differences noted in the New World by Columbus' expedition when it first arrived in the Bahamas. Upon arrival, the members of this expedition did not find the sophisticated and exotic, yet documented land of the Khans they had expected to find. In its place they were greeted by a visage of foreign looking flora and fauna and very small indigenous populations. None of the trees they saw were familiar to them, and there were no goats, or any other recognizable animals. According to Columbus, “All the trees were as different from ours as day from night, and so the fruits, the herbage, the rocks and all things." 32 Moreover, the large mammals present in the Old World were mostly missing in the New. Despite these differences, almost immediately, the interconnection of the two worlds began to make them more homogeneous, a process which Crosby said encompassed the next century. Crosby’s approach was to take a scientific accounting of the consequences of the exchange between the two worlds. He looked at population numbers, crop distribution, and medical data such as comparisons of blood type distribution in the Old

31. Franklin W. Knight, The Caribbean: The Genesis of a Fragmented Nationalism (New York: Oxford University Press, 1990), 70

32. Alfred W. Crosby, The Columbian Exchange: Biological and Cultural Consequences of 1492 (Westport, CT: Greenwood Publishing, 1972), 4. 
World and the New, and concluded that the closed system that was the New World very quickly influenced, and was in turn influenced by, contact with the Old World leading to an increased homogeneity which made both worlds very similar but diminished the variety of the gene pool in the process. Crosby also documented how patterns of disease and crops spread within the New World in unexpected ways. Potatoes, for example, originally existed only in South America, but soon spread to the North American continent by way of Europe where they had quickly become a staple crop. Thus, Crosby inserted a measure of agency to the literature which would influence future research.

The end of the Cold War began to usher in more focused research on the specific influence the United States itself had on the region. Typical of these early post-Cold War studies was Jules Benjamin's, The United States and the Origins of the Cuban Revolution: An Empire of Liberty in an Age of National Liberation (1990). According to Benjamin, Cuba’s independence was directly affected by U.S. expansionism during the previous century, and the Castro regime's alliance with the United States’ Cold War enemy was a direct affront to emerging American power and prestige a mere ninety miles from its coast. Benjamin's book clearly takes a very negative approach to the United States and lays the blame for the emergence of the Castro regime squarely on the shoulders of American policies. He tracked U.S. policy going back to the SpanishAmerican War and found that the Americans from the very beginning established a selffulfilling prophecy of instability in the island, which they never took seriously as a possible partner nation. In fact, Benjamin portrays the United States as never having understood the desires of Cuban nationals for independence and justice and having assumed that they should be happy to accept American hegemony. In his estimation, 
then, the emergence of the Castro regime was nothing but a natural reaction to American interventionism. $^{33}$

Aside from the end of the Cold War, the anniversary of Columbus' voyages affected Caribbean historiography in a similar way as it had impacted the works on the United States and South America mentioned above. Peter Hulme’s Colonial Encounters: Europe and the Native Caribbean, 1492-1797 (1992) is among a series of books analyzing the region around this time. According to Hulme, the coming of European settlers began one of the most dramatic demographic shifts in human history. Hulme touched on this change while examining the origin of the word "cannibal" as it came to be synonymous with man-eater. According to Columbus' diary, his party encountered a population of Arawaks and found that they were greatly afraid of a people which they described as “Caniba” who they said were very war-like and ate people. Columbus' assertion (after some dithering on the subject) was that the use of the word "Caniba" was the native's way of referring to "la gente del gran can." 34 In other words, Columbus was convinced that though they had not found the expansive kingdom of the Khans, it was not far away. One important aspect of this book is that the documentation for this time period is fragmentary at best. Caribbean tribes that were wiped out by invasion, deportation, or disease did not leave any written records to be analyzed. For this reason, Hulme did not limit himself to simple historical sources, but actually included a couple of

33. Jules Benjamin, The United States and the Origins of the Cuban Revolution: An Empire of Liberty in an Age of National Liberation (Princeton, NJ: Princeton University Press, 1990).

34. Peter Hulme, Colonial Encounters: Europe and the Native Caribbean, 1492-1797 (London: Routledge Press, 1992), 22. 
purely literary works; the relations between Prospero and Caliban in William Shakespeare’s The Temptest (1610 1611 est.) and the relationship between Robinson Crusoe and Friday in Daniel Dafoe's Robinson Crusoe (1719). For his part, Hulme referred to these selections as representative rather than comprehensive, and called his book a work of "Colonial discourse." Hulme demonstrated how these different encounters served to stigmatize the Carib population that inhabited the region in a way that was later used by European powers, and later the United States to justify their treatment of the islanders and argues that the very term Carib as well as the suggestions of cannibalism which developed around it was a function of distinguishing the islanders from the Europeans and therefore was a way of establishing 'otherness' among them. To this purpose, the depiction of the islanders as cannibals was an important step in defining them as savage and non-Christian.

Hulme revisited some of his previous issues in his collaboration with Neil Whitehead in their study, Wild Majesty: Encounters with Caribs from Columbus to the Present Day, An Anthology. Here, Hulme and Whitehead sought to give an account of the relations between island Caribs and Europeans over a five hundred year period. Hulme and Whitehead's perspective and their loyalties are clearly with the natives as they were systematically reduced, chased off, and in some cases (such as that of the "black Caribs") deported to Central America where they would form new communities and societies. ${ }^{35}$

35. Peter Hulme, and Neil L. Whitehead, Wild Majesty: Encounters with Caribs from Columbus to the Present Day, An Anthology (Oxford, UK: Clarendon Press, 1992), 2. 
Also in 1992, Phillip Boucher's Cannibal Encounters: Europeans and Island Caribs, 1492-1763 likewise sought tell the story of the early encounters between Europeans and island Caribs in an attempt to deal with unexplored ideas that were brought up by earlier studies. Boucher's main argument, much like Hulme's is that the image of the "Carib" as a man eater was the result of European desires to brand these people as the "other" so that they may be more easily marginalized and if necessary eliminated. Eliminating a human society would have carried with it a very high social and religious stigma that eliminating cannibalistic tribes would not. In many cases, Europeans simply believed Spanish claims about cannibalism without questioning them. This is ironic because as Hulme previously documented, Columbus himself did not believe the stories told by the islanders he encountered, and attributed them to fear caused by the disappearance of members of their populations who would be captured by other tribes (Columbus believed they were being captured by the Khan's people) and would never return. ${ }^{36}$

Boucher's goal was thus twofold; he wanted to dispel the myth of the Caribs as cannibals, portraying them as peaceful people, and document how the differing approaches to colonization had different results. He asserted that the near parity between the populations of English and French settlements in the Caribbean (vs. mainland North or South America) meant that the success of the French approach to relations with these people was not simply due to demographic factors. The French in general had a tradition of humanism which admired the noble savage and saw the islanders with kinder eyes. In

36. Hulme, Colonial Encounters, 22. 
addition, French disappointment at the state of "civilization" allowed for the Caribs to be viewed in a more sympathetic light. He also engages in native agency by positing that the Caribs were initially able to play the different European groups against each other. ${ }^{37}$ Like Hulme, he concludes that the cannibal myth came as a result of trying to differentiate the "good" natives from the "bad" ones but does not believe it had a basis in fact, only Spanish propaganda. Boucher argues that migration patterns were key to understanding the emergence of different cultures and is very detailed in depicting each culture.

Going somewhat counter to these previous books, Jan Rogozinski’s A Brief History of the Caribbean: From the Arawak and the Carib to the Present (1999) sees the Caribbean societies as more than just the result of European colonization. Rogozinski's central theme is that the islands of the Caribbean share a common heritage, regardless of who settled them. He goes a bit further by suggesting that these similarities are the result of not only the colonial experience, but also of geography, weather, geology, and how these influenced the way the region developed. In fact, aside from race and history, Rogozinski feels that even attributes such as weather and difficulty of travel have been central to the similarities and development of the region. ${ }^{38}$ These similarities, however, had the effect of making the native populations susceptible to European, and later

37. Philip P. Boucher, Cannibal Encounters: Europeans and Island Caribs, 1492-1763 (Baltimore, MD: Johns Hopkins University Press, 1992), 61-93.

38. Jan Rogoziński, A Brief History of the Caribbean: From the Arawak and the Carib to the Present. (New York: Penguin Putnam, 1999), Chap. 1. 
American exploitation. The shared experience of American chattel slavery then became the last aspect that would unify the region and give it a distinct character.

In 1994, Robert Freeman Smith's The Caribbean World and the United States: Mixing Rum and Coca-Cola took a more positive outlook on the strained relationship between the United States and the region than earlier works had. Freeman Smith claimed that U.S. foreign policy had been generally successful in the region, and to this end, he cited the region's relative freedom from foreign control and influence. He claimed that (with the obvious exceptions of Cuba and Haiti) freedom, democracy, and respect for human rights were at higher rates than at any time since the Spanish conquest. Though the author admitted that the United States' propensity to use military force had been a troubling practice, he concluded that the actual results had been mixed to positive in that the United States had always voluntarily withdrawn. Moreover, Freeman Smith asserted that lasting peace may never come to the region, as it may never come to the world at large, but did not believe the United States was at fault for this. He also documented the cultural exchanges between the United States and the Caribbean (such as the rum and Coca-Cola of his title) and saw them as being mostly positive as opposed to the result of economic imperialism the way others had. ${ }^{39}$

G. Pope Atkins and Larman C. Wilson's The Dominican Republic and the United States: From Imperialism to Transnationalism (1998) sought to give as definitive a look

39. Robert Freeman Smith, The Caribbean World and the United States: Mixing Rum and Coca-Cola (New York: Twayne Publishers, 1994). 
as possible to the history of U.S. relations with this island nation. The authors tried to remain even-handed but there was a natural bias which came from being mostly confined to using U.S. sources. Coming out at a time when Dominican studies were becoming more popular, this book argued that despite what can easily be seen as an uneven relationship both parties have actually had an influence on each other. This is an issue that was particularly pronounced as U.S. interests increasingly looked toward the Caribbean and have only grown as the Dominican Republic has become a major factor on the war on drugs. Overall, Atkins and Wilson were very critical of the Trujillo dictatorship but seemed enthusiastic about increased relations with the United States. ${ }^{40}$

Also in 1998, Eric Roorda's The Dictator Next Door: The Good Neighbor Policy and the Trujillo Regime in the Dominican Republic, 1930-1945 examined how the Good Neighbor Policy the United States pursued in the face of the growing axis threat affected the balance of power in the Caribbean. This book is part of Duke University Press' series "American Encounters/Global Interactions” and it followed the emerging trend of turning the traditional understanding of the power dynamic on its head. Traditionally, the narrative had been that through the use of American sponsorship, dictators such as Trujillo and Somoza were able to maintain a power base from which to rule their countries and in turn, were subservient to the United States who was ensuring their survival. Roorda, however, found that Trujillo was skillfully able to manipulate the situation himself through the use of balance of power, paid lobbyists, and even occasional

40. G. Pope Atkins and Larman C. Wilson, The Dominican Republic and the United States: From Imperialism to Transnationalism (Athens, GA: University of Georgia Press, 1998). 
bribery to keep the United States on his side despite his admittedly atrocious human rights record. According to Roorda, Trujillo was so successful that he essentially "seized and held the initiative in the bilateral relationship with the United States." ${ }^{41}$ One of Roorda's most successful contributions was his demonstration that the heterogeneity of the U.S. administration and how Trujillo was able to exploit this heterogeneousness for his own goals. Where he fell short is in his depiction of Trujillo himself who tends to come across as a singular force to be dealt with which suggests some agency being employed by the author. Of note, both these last two books demonstrated the growing trend of showing how the influence flowed both ways.

Capitalizing on the fortieth anniversary of the Cuban Revolution in 1999, several books came out regarding U.S. relations with that island. Marifeli Pérez-Stable took a more conciliatory approach than Jules Benjamin had in analyzing the relationship between Cuba and the United States in her book, The Cuban Revolution: Origins, Course, and Legacy. While largely agreeing with some of Benjamin's points, her stated goal was to bridge the gap of systematic historical inquiry that she thought the Cuban revolution had not elicited. She stated her study "subscribes to the main proposition of contemporary Cuban historiography [that] the origins of the Cuban revolution lie in the independence movement against Spain and the frustration of its aspirations in the Cuban republic.” According to Pérez-Stable, the independence movement originally had elements of social justice attached to it which were thwarted by the U.S. intervention not Dominican Republic, 1930-1945 (Durham, NC: Duke University Press, 1998), 90. 
letting Cuba become independent under its own terms. Despite this, Pérez-Stable was not as outwardly critical of the United States as Benjamin and wished for reconciliation between the two nations. ${ }^{42}$

Also that year, Ada Ferrer's Insurgent Cuba: Race, Nation, and Revolution, 18681898, took a narrow look at the thirty-year period during which Cuba gained its independence. ${ }^{43}$ This book was much more concerned with race and class than previous efforts, in line with the current trend in American historiography, but did not exclusively point the finger at the United States for Cuba’s racial problems. Ferrer argued that as a result of the three wars which were fought to bring Cuba's independence from Spain, the Cuban insurgents came to seek an egalitarian society shared by black and white Cubans alike, which was in stark contrast to the racism that had increasingly arisen in the United States at the time. According to Ferrer, the initial failures of the revolutionary movements were due to the exploitation of racial tensions by the Spanish who effectively scared the white insurgents out of accepting their black counterparts and drove a wedge between the two. Unlike Benjamin's implicit assertion of racism, Ferrer argued that the increasing amount of racism was not a result of American attitudes being forced on Cubans, but that of the white insurgents re-asserting attitudes that they had put aside in the interest of creating a united front now that the conflict was coming to an end. Of particular note, Ferrer argued that success in revolutionary endeavors only came about

42. Marifeli Pérez-Stable, The Cuban Revolution: Origins, Course, and Legacy (New York: Oxford University Press, 1999), ix.

43. Ada Ferrer, Insurgent Cuba: Race, Nation, and Revolution, 1868-1898 (Chapel Hill, NC: University of North Carolina Press. 1999). 
after the Cubans were able to get past these divisions, leaving the Spanish without the ability to divide and conquer and made them have to depend on their inferior military position. The struggle was actually three different struggles, the first two of which succumbed to racial strife while the third one was successful by rising above it, though she claims that the racial hierarchy eventually reasserted itself. According to Ferrer, this reassertion took place before the entry of the Americans so they could not be faulted for it.

As the new century began in a unipolar world, a growing trend was to look at how the United States had dealt with the region militarily. Mary Renda’s Taking Haiti: Military Occupation and the Culture of U.S. Imperialism, 1915-1940 (2001) looked at a neglected chapter in Haitian-American relations: the first U.S. occupation in Haiti. Renda's analysis was not simply the traditional narrative of domination, but actually took the position that the events surrounding the first U.S. occupation actually had a cultural effect on the United States that was at least as significant as the effect that it had on Haiti. She also took a strong look at gender roles in the occupation and its aftermath. The book argued that despite being largely ignored, this incident was actually a major event in the history of both nations. Renda asserted that the (as she calls it) "United States American" occupation of Haiti was a pivotal moment in the history of both nations. The United 
States, emerging as it was onto the world stage, took the opportunity to assert its power over the weaker nation in the name of a form of paternalism. ${ }^{44}$

Renda examined how the idea of paternalism was particularly appealing to American Marines who were adjusting to the changing roles of masculinity back home as the women's movement and increasing industrialization took away the individualistic tendencies in male roles. Renda further argued that, "Wilson's policy toward Haiti did not result from the failure of his liberal vision ... but rather from the logical, if usually hidden, implications of that vision," though she did not necessarily follow through on what this might mean for liberal thought. In this, she broke from the traditional narrative that Woodrow Wilson's benevolent goals were undermined by the inherent bigotry displayed by the many southern soldiers who made up the occupation. Interestingly, Renda did not always portray this paternalism negatively and made it clear that some Marines saw themselves as stewards of the population. Indeed, Renda took great pains to try to capture their story through letters, postcards, journal entries, and actual written orders, but the power relationship was always such that any disobedience would be seen in the most negative light possible, as of a father needing to discipline an unruly child. ${ }^{45}$

Looking at the effect the Haitian revolution had on the United States, Gordon Brown's Toussaint's Clause: The Founding Fathers and the Haitian Revolution (2005) used contemporaneous documents to provide a glimpse into the diplomatic process via

44. Mary A. Renda, Taking Haiti: Military Occupation and the Culture of U.S. Imperialism, 1915-1940 (Chapel Hill, NC: University of North Carolina Press, 2001). P115.

45. Renda, Taking Haiti, 115. 
which the early United States dealt with the newly independent Haitian nation. ${ }^{46}$ Interestingly, Brown’s narrative did not portray the early American republic as necessarily hostile to Haitian independence. In fact, the very title of the book refers to a specific clause which exempted Haiti, (then St. Domingue) from an embargo aimed at France during its “quasi-war” with the United States; a high water mark of United StatesHaitian relations. This relationship became soured after the election of the strongly proFrench Thomas Jefferson, but even here Brown noted that the fallout was not immediate and was predicated on external diplomatic factors. Despite the fact that Jefferson was a slave owner, his relationship with Haiti was, according to Brown, mostly guided by American interests vis-à-vis its relationship with France and sometimes Britain. Brown did not necessarily attribute major hostility toward Haiti as being driven by racism either, but by diplomatic policy and necessity.

Also examining U.S. military adventurism in the Caribbean, Harvey Neptune’s Caliban and the Yankees: Trinidad and the United States Occupation (2007) looked at the American intervention in Trinidad during the war years. Much like Renda’s book, Caliban is largely a work of social history that looks at the specific period of U.S. presence in Trinidad which the local population refers to simply as the "occupation.” Ostensibly there as part of a "Destroyers for Bases” agreement, United States servicemen soon arrived in numbers that were significant given the relatively small population of the island (25,000 troops for an island of 500,000 according to Neptune). Though alternately

46. Gordon S. Brown, Toussaint's Clause: The Founding Fathers and the Haitian Revolution (Jackson, MS: University Press of Mississippi, 2005). 
referred to as a time of exploitation or cooperation by either one of the participants, Neptune argued that the relationship was actually remarkably ambiguous from beginning to end. This is particularly fascinating because at the time, Trinidad was a British possession and not an independent nation, so in effect the American presence was undermining the authority of one of its allies in the war. American servicemen having encounters or even developing relationships with Trinidadian women of color also undermined British practices of racial separation. ${ }^{47}$

Interestingly, instead of mobilizing against the United States occupation as happened elsewhere in the Caribbean, Neptune found that Trinidadians embraced the base and took advantage of the opportunities the American presence brought with it. Ironically this still contributed to decolonization not by galvanizing opposition to the occupier, but by undermining the power of the colonizing power. There are several factors that seem to have contributed to this including the fact that the United States was not the colonial power, and the fact that the United States presence was understood to be temporary and was actually there to provide protection against German forces which were perceived as an actual threat. Neptune further looks at the cultural influence that the occupation had including looking at things such as fashion and music (Calypso music is said to have developed around this time). It is interesting to note that Neptune used the same analogy as Hulme had fifteen years prior by identifying the Trinidadian people with the character of Caliban in Shakespeare's The Tempest, though in this case, highlighting

47. Harvey R. Neptune, Caliban and the Yankees: Trinidad and the United States Occupation (Chapel Hill, NC: University of North Carolina Press, 2007). 
the amicable relationship that existed with Prospero rather than the "otherness" of the character.

Continuing with the trend of looking at the relationship militarily was Jason Parker's Brother's Keeper: The United States, Race, and Empire in the British Caribbean, 1937-1962 (2008). Parker used a largely Braudellian Mediterranean model in his analysis and mostly ignored the social history side of the events, although he was writing about roughly the same period as Neptune. He found a much different relationship between the United States and Trinidad (and in this case also Jamaica). Though he acknowledges the importance of the Caribbean Basin to the protection of the area around the time of the war, the fact that he continued his narrative well into the Cold War is significant, and may explain why his conclusions differ from those of Neptune. Islanders who might have welcomed a U.S. presence during the war under the assumption it was temporary and only meant to exist during the conflict, would have had a much different view as this presence continued past the stated conflict and into the Cold War era. Parker is not as interested in social history as Neptune was, focusing more on the diplomatic relations between the governments of the United States, Great Britain, and the two island nations. Parker did look at something Neptune neglected which is the role that Caribbean expatriates had in influencing U.S. attitudes once they came to the United States. Also, Parker's time period allows him to look at aspects of the relationship which 
fall outside Neptune's book such as how the Cuban Revolution affected U.S. policies toward the Caribbean islands. ${ }^{48}$

As can be seen, actual works dealing with the Caribbean Defense Command are something that is difficult to come by, and the history of joint commands only recently began receiving attention. For now, searches for pertinent literature necessarily have to look at tangential issues in other books. Much of the available literature has traditionally subscribed to the dependency theory, characterizing the United States as an imperial power over the region. Typical of this approach is Jack Nelson- Pallmeyer's School for Assasins: The Case for Closing the School of the Americas and Fundamentally Changing U.S. Foreign Policy (1997). ${ }^{49}$ As the title implies, Pallmeyer argues that U.S. involvement in the region has been largely negative and detrimental. As referenced above, Harvey Neptune’s Caliban and the Yankees and Jason Parker’s Brother's Keeper which came ten years after School for Assassins, dealt more closely with the specific period and setting and took a slightly less negative approach with Neptune calling the relationship ambiguous and Parker characterizing it as positive, at least during World War II. Coleman's previously cited book, Colombia and the United States, which came out the same year as Parker's also continued the trend of characterizing the U.S.-Latin American relationship in a less negative light.

48. Jason C. Parker, Brother's Keeper: The United States, Race, and Empire in the British Caribbean, 1937-1962 (Oxford, UK: Oxford University Press, 2008).

49. Jack Nelson-Pallmeyer, School of Assassins: The Case for Closing the School of the Americas and for Fundamentally Changing U.S. Foreign Policy (Maryknoll, NY: Orbis Books, 1997). 
The most direct treatment of the subject is Cynthia Watson's Combatant Commands: Origins, Structure, and Engagements (2011). ${ }^{50}$ Watson is mostly concerned with bringing the reader up on the current state of affairs and thus choses to focus simply on the existing COCOMs , though she does give brief histories of previous ones. Looking at almost exclusively open-source American documents however, she largely neglects to look at the nations which encompass the AORs of these commands and approaches the subject from a purely American perspective. Overall, her treatment of the relationship the United States has with the nations in these AORs is predominantly one of cooperation, in line with Bradley Coleman's analysis, which is to be expected from an American military historian writing on contemporary events where the new military paradigm is to see these as partner nations. Her book follows a narrative structure and has a separate chapter for each command. Because of her emphasis on the current command structure established by the 1947 Unified Command Plan, she treats Pacific Command as the oldest of the joint combatant commands and places Southern Command as the third to be established (after EUCOM) because of its establishment in 1963. Watson does not go very heavily into the history of SOUTHCOM's predecessor commands, and dedicates two lone paragraphs totaling less than one page to the CDC. Watson argues that the current system of joint regional combatant commands is actually the result of a gradual evolution which began in 1947 following the establishment of the Unified Command Plan, as an early move in the Cold War, and was prodded along by historical events which resulted in fledgling attempts to engage diplomatically with the

50. Cynthia A.Watson, Combatant Commands: Origins, Structure, and Engagements (Westport, CT: Praeger Security International, 2011). 
nations of each command's respective region. Thus, she sees the current system of regional COCOMs as being the result of the natural evolution of the military in line with trends that reached back to the United States' traditional distrust for military power. She also argues that this trend culminated in the final division of the entire globe under different regional COCOMs in a process that began in 1947 and culminated with the 2007 creation of Africa Command.

Challenging both Nelson-Pallmeyer and Watson, this dissertation will demonstrate that the process which led to the current state of regional combatant commands actually predated the 1947 Unified Command Plan and formally began in 1941 with the creation of the Caribbean Defense Command, and that the CDC was both an early (albeit imperfect) attempt to engage with the nations of the region and an early foray into what would later be called a "whole of government approach.” I will demonstrate that it was this attempt then, which set the stage for the 1947 reforms which led to the eventual establishment of the COCOM system as it is today. 


\section{CHAPTER 1: Background}

The establishment of the Caribbean Defense Command actually preceded U.S. entry into World War II, though not by much. This was as much a demonstration of how seriously the threat of war was being taken as of how prescient U.S. planners had been in their assessments of the situation. The work of setting up the CDC was both military and diplomatic. As the nearest point of U.S. authority in the region, it would become an easy venue for foreign governments to communicate with the United States. Like the combatant commands that would come after it, the CDC would also oversee various subordinate commands, normally encompassing a single branch of military service which would all have to be brought together to enact a comprehensive and consistent military plan for the region. This would mean that logistics would be a constant effort throughout the Command's history.

During the years preceding the U.S. entry into World War II, while officially pursuing a path of neutrality, the Franklin Roosevelt administration became increasingly concerned with the possibility of hostilities spreading to the western hemisphere. Of particular note was the presence of Axis sympathizers within Latin America, and the relative lack of protection of the Panama Canal and its access points which posed a serious problem due to their very nature. Building the Canal had been a monumental feat of logistics and engineering, and it was (and remains) a highly sophisticated system which depends on intricate workings and various moving parts. Sabotage of any of a number of these parts could easily render the canal inoperable. The Canal was not only a major passageway for commerce and a huge logistical asset, but also ironically, had 
become both a symbol of American power in the region and a potential weak spot in the U.S. defenses. It was widely assumed that the Canal would present a very tempting target to any possible belligerents should the United States enter the war.

Another problem facing the Canal and Canal Zone was a consequence of the tortured history of its creation. The actions the United States had taken in order to secure the legal rights to build the canal were among the most controversial in the history of inter-American relations. The United States had initially sought to build a canal through Nicaragua, while a competing French effort was underway in Panama. The French effort fell apart leaving some of the initial infrastructure and planning in place looking for new investors. After several surveys determined that Panama would be the most viable location for such a canal, the United States purchased the rights to the French effort and began work toward completing it. ${ }^{51}$

At the time, Panama was still a part of Colombia and while negotiating with the Colombian government for rights to build the canal, the United States had initially assured the Colombian government of its commitment to respect Colombia’s territorial integrity. Things took a turn for the worse when negotiations stalled, and the United States switched course and effectively supported a Panamanian separatist movement which they felt would be more amicable to American demands. The separatists in effect traded access to the Canal Zone for U.S. backing of Panama's newly established sovereignty. The United States had not actually taken any military action throughout this

51. Jon T. Hoffman, The Panama Canal: An Army's Enterprise (Washington, D.C.: Center of Military History, United States Army, 2009), 6, accessed February 28, 2014, http://catalog.hathitrust.org/api/volumes/oclc/469627028.html. 
crisis but it did take a series of actions designed to delay the Colombian government's response to the rebels until the point became moot. Although these actions were widely condemned, most of the neighboring countries had by that time already recognized Panama's independence. By its actions, the United States had made the retention of the province by Colombia impossible.

This episode tainted the United States' relationship with Colombia for many years, and was a cause of great criticism among many in Latin America, though it initially had mixed effects on actual diplomatic relations with the rest of the Andean nations. As historian Stephen Randall would later state,

The actions of the Theodore Roosevelt administration in the crisis of 1903 rightly earned Colombian wrath. United States encouragement of secessionist leaders, the almost immediate recognition of the rebel government as an independent republic, the immediate conclusion of a canal treaty with representatives of that government, and interference with Colombian military forces attempting to suppress insurrection made impossible Colombian retention of the isthmus. ${ }^{52}$

Even Samuel Flagg Bemis’ very pro-American take on it said the incident was a "really black mark in the Latin American policy of the United States" which he claimed was only rubbed off "after much grief by the reparations treaty of 1921.”53

Notwithstanding Bemis' claims that the stigma of U.S. actions had improved, relations had not really markedly changed in the years leading up to World War II. The U.S. proceeded with the building and later running of the Canal, but aside from the nearly

52. Randall, Colombia and the United States, 80.

53. Bemis, Latin American Policy of the United States, 151. 
universally lauded technical achievement of succeeding, relations remained poor for some time.

The Canal was completed in 1914, almost concurrently with the beginning of World War I. In fact, the first test crossing of the Canal on August 3, 1914 by the cement barge Cristobal happened on the same day that Germany declared war on France. ${ }^{54}$ The Canal Commission which had overseen the construction phase of the Canal was officially replaced by the Canal Zone administration, which was largely Army Centric, and this remained the status quo during the war. Interestingly, the First World War was not as significant an event for the region as the Second would become, and there was no attempt to form a joint command as would happen in 1941. This was likely due to several factors. The United States did not enter the war until 1917, and when it did, it did not face a two front war where the Canal would serve as a vital waterway to supply the American military machine. The Canal, moreover, was relatively new and untested so its value was not immediately apparent. Furthermore, German submarine activity ironically hid the potential value of the Canal by severely reducing commercial shipping through the Canal. In fact, the Canal was so sparsely used that one estimate claimed the daily number of transits through the Canal during the war could be "counted on the fingers of one hand." 55

54. Hoffman, Panama Canal, 73.

55. Hoffman, Panama Canal, 74. 
In the years after the First World War, while pursuing a somewhat isolationist policy, the United States had remained engaged in the region, but had largely neglected diplomacy with its southern neighbors, preferring often heavy handed military intervention such as in Panama, Haiti, Honduras, and the Dominican Republic. As a result, by the mid-1930s both diplomatic relations and the reputation of the United States in the region had suffered. This made the Canal Zone an American exclave of significant size surrounded by what was perceived as increasingly hostile neighbors. Should war break out, a large population of American citizens living in the Canal Zone, including many members of the military would be isolated in a region that was not predisposed to treat them kindly. It was clear that a simple military solution would not easily suffice in dealing with all these issues. Should the Canal Zone be quickly overrun by a hostile force, the likelihood of large numbers of American prisoners or hostages likely loomed large in the minds of decision makers. Military doctrine often stresses that weakness provokes aggression, and the Canal and Canal Zone projected a major potential Achilles heel to the United States in a time of spreading global conflict.

Another problem with defending the Canal was a purely logistical one. The Canal Zone was traditionally under the care of the U.S. Army. Although the Army is traditionally the right venue for protection of territory from land based attacks, the Canal can be approached from either land or water. What aviation assets existed still fell under the Army Air Corps, but the technology of the time was not robust enough to effectively project American power or protection over the entire Caribbean, or of reaching the Canal from the continental United States in time and with enough strength to make a difference 
should things turn sour. This weakness had the potential to affect all the paths leading to the Canal itself. Ideally, any plan to protect these approaches would have to rely partly on sea power, meaning that they would necessarily have to rely on the U.S. Navy. Interservice cooperation was not something that could easily be counted on in times of peace where competition for resources was a constant point of contention, but it would be necessary if any significant plan could be put in place to effectively protect the Canal in a time of war. It was clear in the years leading to war that as much of an asset as the Panama Canal and Canal Zone were, they presented a unique challenge in maintaining the U.S. defense of the hemisphere. The Canal had to be defended, but its defense had to encompass an overall approach that would marry ground, air, and naval forces in a coordinated and comprehensive plan which would be directed by a single head.

The solution lay in the establishment of a new and innovative entity. The Caribbean Defense Command was formally established in 1941and its various components and subcommands were activated shortly thereafter. Though it would never quite function as well as intended, it would serve as a prototype military command which would deal jointly with the different branches of the services (mostly Army and Navy) in a manner that would later be adopted throughout the U.S. military.

\section{Setting the Stage}

The activities which led to the creation of the Caribbean Defense Command began before the war in Europe was formally declared. These took the form of diplomatic moves in which the United States first sought to improve its relationship with its southern neighbors. German aggression and territorial expansion were on the rise, and 
the relative weakness of some of the nations in Latin America, as well as the known existence of Nazi sympathizers within their borders, had the potential to make them susceptible to foreign influences. This phenomenon, however, was not entirely lost on the Latin American nations themselves and in a series of meetings, various international agreements were hammered out with the aim of diminishing any possible foreign aggression. An Inter-American conference was held in Buenos Aires in 1936 which resulted in the creation of the "Declaration of principles of inter-American solidarity and cooperation.” 56 Though it did not single out any aggressor by name, it demonstrated a marked fear that Axis aggression in particular would spread to Latin America. ${ }^{57}$ This was later joined by the "Declaration of Lima” which followed a meeting by nations in continental South America. Established in December 1938, this Declaration cemented the resolve of all parties involved to act in solidarity "in case the peace, security, or territorial integrity of any American Republic is threatened by acts of any nature that may impair them.”58 Finally, the Declaration of Panama in September of 1939 aligned Central American nations with the United States in the creation of a maritime security zone. ${ }^{59}$ Though never officially stating it, inclusion of the United States into these

56. History of the Caribbean Defense Command, Introduction and Background. Internal U.S. Caribbean Defense Command Report, 1945, Archives of the United States Southern Command, Miami, Florida [hereafter, SOUTHCOM Archives], “CMH CDC 08.2.08 AA,” p. 5. (Hereafter cited as History of the Command.)

57. History of the Command, 5.

58. U.S. Congress, Department of State. Foreign Relations of the United States. Diplomatic Papers, 1938. (In five volumes) Volume V. The American Republics. Serial Set Vol. No. 10355-5, Session Vol. No. 36, 76th Congress, 1st Session. H.Doc. 473 Vol.5, pp. 83-84 and 88.

59. History of the Command, 5. 
meetings and agreements signaled a willingness to accept U.S. leadership in defense of the region.

The idea of possible invasion, though, was not the only issue of concern to the region. Once war formally broke out, a more concrete concern arose following the quick capitulation of France and Holland. Both of these countries had territorial possessions in the Western hemisphere. Dutch colonies in the Caribbean had existed since early on in the age of discovery, and both countries had Caribbean possessions as well as large colonies in continental South America, French Guiana, and Dutch Guiana (now Surinam). The fall of these two countries to the Axis forces brought into question the status of French and Dutch colonies. The very different status of the two countries once conquered, as well as their relationships with their colonies before the war, further complicated matters in dealing with the colonies. Dutch colonies were traditionally far more independent than French colonies and seemed determined to protect their territorial integrity and sovereignty. French Guiana and the French West Indies, however, were loyal to the Vichy French regime which had been established as a puppet regime of the greater German Reich and which had quickly adopted Nazi practices and institutions. ${ }^{60}$ Having a regime allied with Nazi Germany on the continent gave the Axis a potential beach head in any attempts to spread the war to the Western Hemisphere. This troubling

60. Robert Aron, The Vichy Regime, 1940-44 (Boston: Beacon Press, 1969), 163. Among the first official actions of the Vichy Regime were the criminalization of dissent and belonging to subversive organizations, in effect negating the Rights of Man which had been part of French legal tradition since 1789. 
development eventually led to a meeting in Havana, Cuba in July 1940 where attending nations attempted to iron out a framework for cooperation during wartime. ${ }^{61}$

The newfound cooperation among the nations of Latin America was a stroke of luck for the United States, as it continued the process of attempting to repair its reputation with the region. While the 1903 Panama treaty had been toxic to U.S.-Panama relations, and the 1921 revision was only marginally more popular, a new 1936 revised treaty which had sought to position Panama as a partner was better received if not altogether satisfactory. Some of the new terms were still of concern to Panama, but overall the relaxed restrictions on its citizens as well as further protection of territorial integrity was enough to keep the government of Panama from outright opposing U.S. military efforts. In the end, Panama fully, if grudgingly, met all the requirements of the revised treaty as it pertained to the war effort. ${ }^{62}$ By the fall of 1940, bi-lateral military staff conversations had occurred with almost every Central American, South American, and Caribbean republic totaling 20 out of 21 nations to provide the United States support to resist axis inspired subversive elements. Only Panama abstained from these and the official summary suggested this was because they would deal directly with the Commanding General of the Panama Canal Department. In every one of these cases, a satisfactory bilateral basis for cooperation was established. ${ }^{63}$

61. History of the Command, 6.

62. Michael L. Conniff, Panama and the United States: The Forced Alliance (Athens, GA: University of Georgia Press, 2001).

63. Appendix 1; Summary of Staff Conversations with American Republics, August-October 1940, SOUTHCOM Archives, “CMH CDC 08.02.8 BA,” p. 1. 
The issue of cooperation was key in both the establishment and work of the Caribbean Defense Command. The United States found that it had a fairly open road to cooperation from its southern neighbors many of whom were just as fearful of the war spreading to the region. In fact, following the Pearl Harbor attack, Nicaragua immediately offered its territory (land, water, and air) for U.S. use as long as the war persisted. Nicaragua was not alone. Cuba and El Salvador granted the United States permission to fly planes over their territory in early $1942 .{ }^{64}$ Colombia offered up part of its territory for a seaplane base after Axis submarines sank one of their Schooners and killed several of their military personnel. Around this time, the Peruvian government asked for U.S. assistance in fortifying its coastal defenses and was offered supplies via lend-lease agreements. ${ }^{65}$ Even Chile, which had a traditionally poor relationship with the United States and a significant population sympathetic to the Axis cause, was eventually persuaded to break with the Axis despite several strong ties to both Germany and Italy. ${ }^{66}$ By the end of hostilities, nearly every nation in the region had entered the war on the side of the Allies, many of them lending material support, though only Brazil sent a significant military presence.

64. Marion L. Evans, Anti-Submarine Activities in the Caribbean Defense Command 1941-1946. Internal CDC Report, April 1947, SOUTHCOM Archives, "CMH-08-028 AU Caribbean Defense Command AntiSub,” 44-45. (Hereafter cited as Evans, Anti-Submarine Activities.)

65. Lend-Lease Activities in the Caribbean Defense Command. Prepared by the Historical Section, Caribbean Defense Command, June 1947, SOUTHCOM Archives, “CMH CDC 08.002.8 AQ,” p. 20.

66. Chile and the War Effort. Internal CDC Report, June 14, 1946, SOUTHCOM Archives, "CMHCaribbean Defense Command 08.02.8 BE C1.” 
The nature of the enemy turned out to be a fortunate factor for the United States as it made it easier to pursue partnerships with its overwhelmingly non-Aryan neighbors to the south. Additionally, the nature of the staff conversations made it clear that many of the nations of Latin America were fearful of attacks from a "non-American” state or by proxy from fifth column supporters of such a state. ${ }^{67}$ The years leading up to the war would turn out to be fruitful for expanding diplomatic efforts, if nevertheless frustrating in uncertainty about the future. The perceived threat to the region from Axis aggression would play a large role in the preparations that the United States was able to have in place by the time it entered the war.

67. Appendix 1; Summary of Staff Conversations with American Republics, August-October 1940, SOUTHCOM Archives, “CMH CDC 08.02.8 BA,” p. 45. 


\section{CHAPTER 2: 1935-1941, Preparing the Way}

As stated, the years leading up to the creation of the Caribbean Defense Command, and the U.S. entry into the war were filled with a great deal of preparation and movement in the Caribbean. Many of the preparations included the creation and activation of several military units. All the military units that were activated throughout this period, however, were single service (usually either Army or Navy), lacking any joint command structure. The only large headquarters in the region, the Panama Canal Zone administration, was Army-centric and lacked any joint makeup. Still, the work which eventually led to the creation of the Caribbean Defense Command began long before any formal decision was made to create such an entity. On September 11, 1935, Army/Navy policies and procedures regarding joint action had been adopted. These policies would serve as the basis for the Joint Army/Navy defense plan which would then be the basis for the formation of the Caribbean Defense Command. According to this plan, military missions were to be divided between Army, Navy, and Panama Canal Department Administration in the following manner:

- Army: was to defend the canal from sabotage and hostile attacks.

- Navy: was to patrol the coastal zone and control and protect shipping therein.

- Panama Canal Department Administration: was to protect and operate and maintain the canal, its adjuncts and appurtenances to ensure continuous service at the required levels. ${ }^{68}$

68. History of the Command, 8. 
The above policy was based on the idea that the Navy was the first line of defense and there was little chance of enemy naval and air attack on the Canal unless the navy first failed catastrophically in its mission, or the canal was damaged either by attack or sabotage limiting the U.S. fleet to a single ocean. Military assessments determined that a large scale attack on the Panama Canal was unlikely, and increased air range by U.S. warplanes made possible by advances in aviation technology made it even less likely. The same advances however did increase the possibility of air raids, and the possibility of air raids was initially a major concern among the leadership of the CDC. ${ }^{69}$ Still, although the aviation technology of the time could allow for the patrolling of the areas around the Canal, it was insufficient to both patrol and protect the entire Caribbean, leaving the task of protection to the Navy.

In order to assist with the task of protection of the region and establish a clear ability to both patrol and defend the Caribbean, the Puerto Rico Department was established in May, 1939 as an overseas department. This was a military headquarters tasked with a specific portion of the Caribbean. It was completely separate from the Panama Canal Department and subordinate element to the 2nd Army Corps. The Antilles Department was established in a similar manner. At the time, naval forces stationed in the Panama Sea Frontier also had completely different missions and absolutely no relationship to those operating in the Antilles Department ${ }^{70}$ The Puerto Rico Department

69. F.M. Andrews, Commanding General, Headquarters Caribbean Defense Command. Memorandum for the Secretary of War, March 12, 1942, RG 548, Stack B190, Row 1, Compartment 22, Box 305, Folder 376.21, Unity of Command.

70. History of the Command, 3. 
would remain as a separate department throughout the war, though all of these commands would eventually be subordinated under the Caribbean Defense Command.

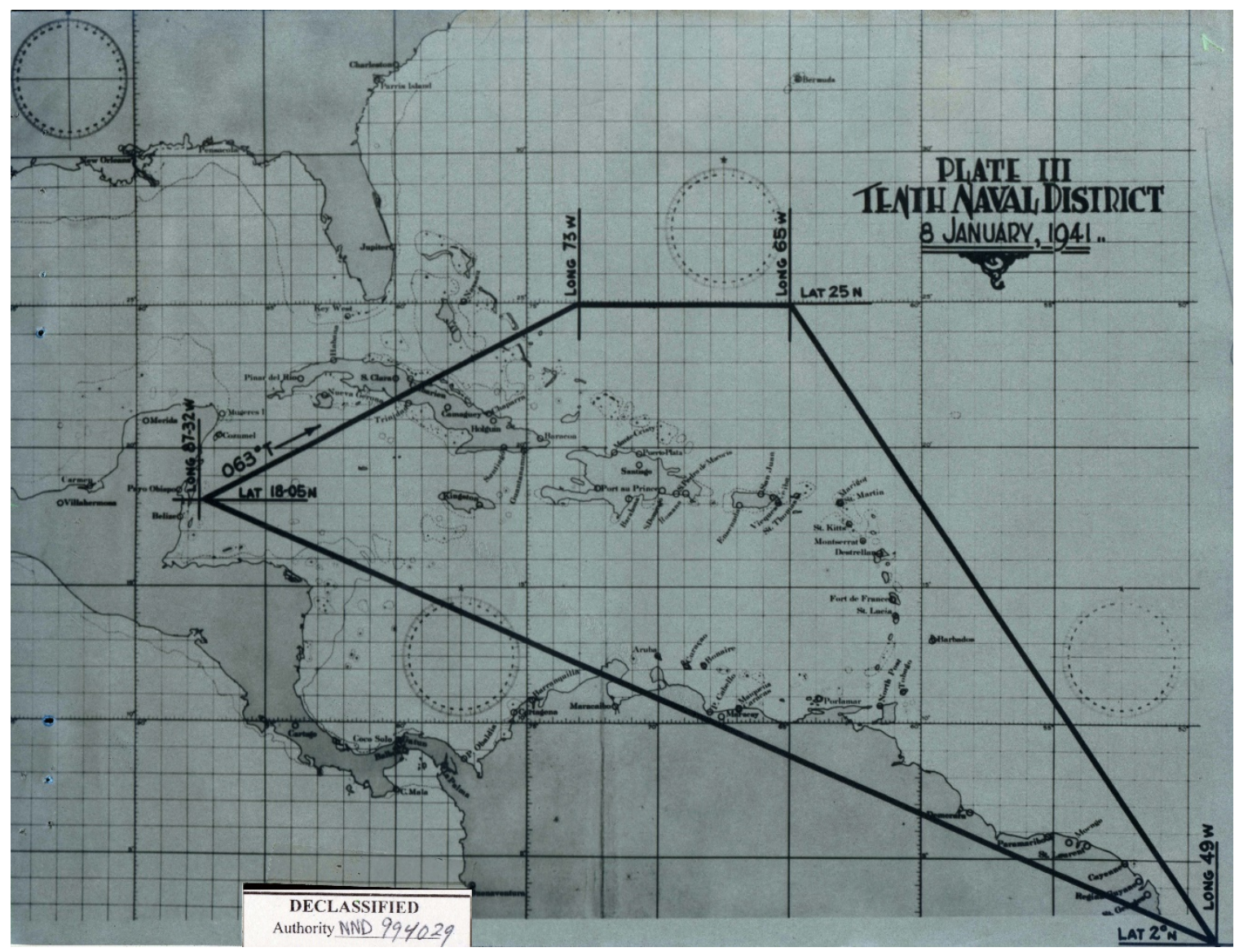

FIGURE 2: The 10th Naval District on 8 January 1941.

Source: An Administrative History of the Caribbean Sea Frontier, RG 548, Stack Area B190, Row 1, Box 329, Container 314.7 Military Histories, p. 7.

On September 5, 1939, the Panama Canal and Canal Zone were put under

exclusive jurisdiction of commanding general of the Panama Canal Department. This in effect, reduced the role the Governor of the Canal Zone had traditionally enjoyed over the area, something that had not even been done during World War I. $^{71}$ Troops from both the

71. Franklin D. Roosevelt, Executive Order dated September 5, 1939, Control of the Panama Canal and the Canal Zone, RG 548, Stack B190, Compartment 22, Box 305, Folder 376.21, Unity of Command. 
Puerto Rico Department and Panama Canal Department were simultaneously augmented in size. By December 31, 1940, the Panama Canal Department troop numbers were approximately $27,850 .{ }^{72}$ Still, the growth of these separate entities was hampered by the lack of joint structure. Naval units at the beginning of 1941 were under the command of what was called the $10^{\text {th }}$ naval District which encompassed most of the Caribbean including the northern coast of South America (see Figure 2).

Increasing the size of the forces in the Canal Zone was made more difficult by the realization that such enlargement was a double edged sword. A major problem with trying to mobilize the U.S. military to a wartime footing was quite simply that the United States was not yet at war, and entry into the war was still not supported by a majority of the population. This made gearing up for war both legally and ethically questionable, as well as diplomatically dangerous. New troops entering the region also had to be conditioned and trained in both the logistics of defending the region and surviving in a tropical climate. On July 26, 1940, the nucleus of the General Headquarters U.S. army was activated and had responsibility to administer training of field forces. This nucleus was intended only for training and administrations and was not responsible for planning for policy decisions. The need for additional troops for all stations eventually made recruiting new service members an increasingly important issue. On September 16, 1940, the President signed the selective service act into law and registration began on October 16 of the same year.

72. History of the Command, 8. 
The Roosevelt Administration came to the conclusion that since in time of war there would be one commander for the theater, there should also be one commander for preparations of the theater prior to war. ${ }^{73}$ With this in mind, it became evident that unity of command was absolutely essential. Unfortunately, the haphazard way in which the Caribbean defenses had so far been established had not included any unity of command. The existence of autonomous or later semi-autonomous military units in the region would continue to be a stumbling block throughout the war effort, which would ultimately complicate the work of the Command. In fact, the initial idea was for unity of land based military command alone. Adding unity with naval forces was initially "left to a later date. ${ }^{74}$

The difficulties in coordinating all these competing issues, especially as they related to the Canal, Canal Zone, and Latin America in general, were among the major reasons behind the creation of the Caribbean Defense Command. The Command was officially ordered into existence in February of 1941, a full ten months before the Pearl Harbor attack. The CDC was a prototype unified military organization designed to defend both the Panama Canal and the Caribbean from Axis aggression. That this was actually done before the Pearl Harbor attack which brought the United States into the war was not as unusual as it might first appear. The United States had been directly or indirectly preparing for war for some time, and had acquired and created several military

73. The idea of having a supreme commander for all forces in the Caribbean and Latin America was similar to what ended up happening in Europe when Eisenhower was named Supreme Allied Commander in Europe.

74. History of the Command, 3. 
assets for this purpose. By the terms of a 1940 agreement, the United States had delivered fifty outmoded destroyers to the British navy in exchange for several British Caribbean bases. This agreement, aside from assisting Britain by providing much needed military hardware, had left the United States with responsibility for several bases spread throughout the Caribbean and reinforced the U.S. role in its defense during the conflict. It also forced the United States to act strategically to defend its newly acquired bases as well as the region that surrounded them. ${ }^{75}$ The bases from Britain were to be added to prior conquests from Spain and purchases from Denmark. Due to the unsure nature of the war, and the possibility of outside influence from occupied nations, the United States at first considered the Europeans Axis powers as well as the Japanese as likely threats. ${ }^{76}$ Thus, in the plan approved on August 14, 1940, the Caribbean was earmarked as a "theater of probable initial operations."77

The British bases acquired via trade included five in the Caribbean theater: Trinidad, Antigua, St. Lucia, British Guyana, and Jamaica. As seen in Figure 3, these bases were spread throughout the Caribbean, though concentrated toward the SouthEastern portion which put them some distance from the Panama Canal. None of these bases was in any condition to be put to immediate use, and all needed garrisoning and supplies forcing the new command to begin preparing plans to develop, garrison and

75. Proposed Outline of Preliminary Studies, Antilles Department. Internal CDC Report, March 28, 1946, SOUTHCOM Archives, Caribbean Defense Command 08.02.10 AO,” p. 4. (Hereafter cited as Proposed Outline, 1946.)

76. History of the Command, 2.

77. History of the Command, 3. 
employ the bases from scratch. Employment of the bases would be under the direction of the War Department General Staff. The status of foreign military bases in the region was of continuing concern however, and the War Department also considered the possible necessity of protective occupation of Western Hemisphere European possessions, as well as the possible use of armed forces to assist Latin American partner nations in thwarting attacks by axis or subversive groups and collaborating with the armed forces of said partner nations in joint operations. ${ }^{78}$

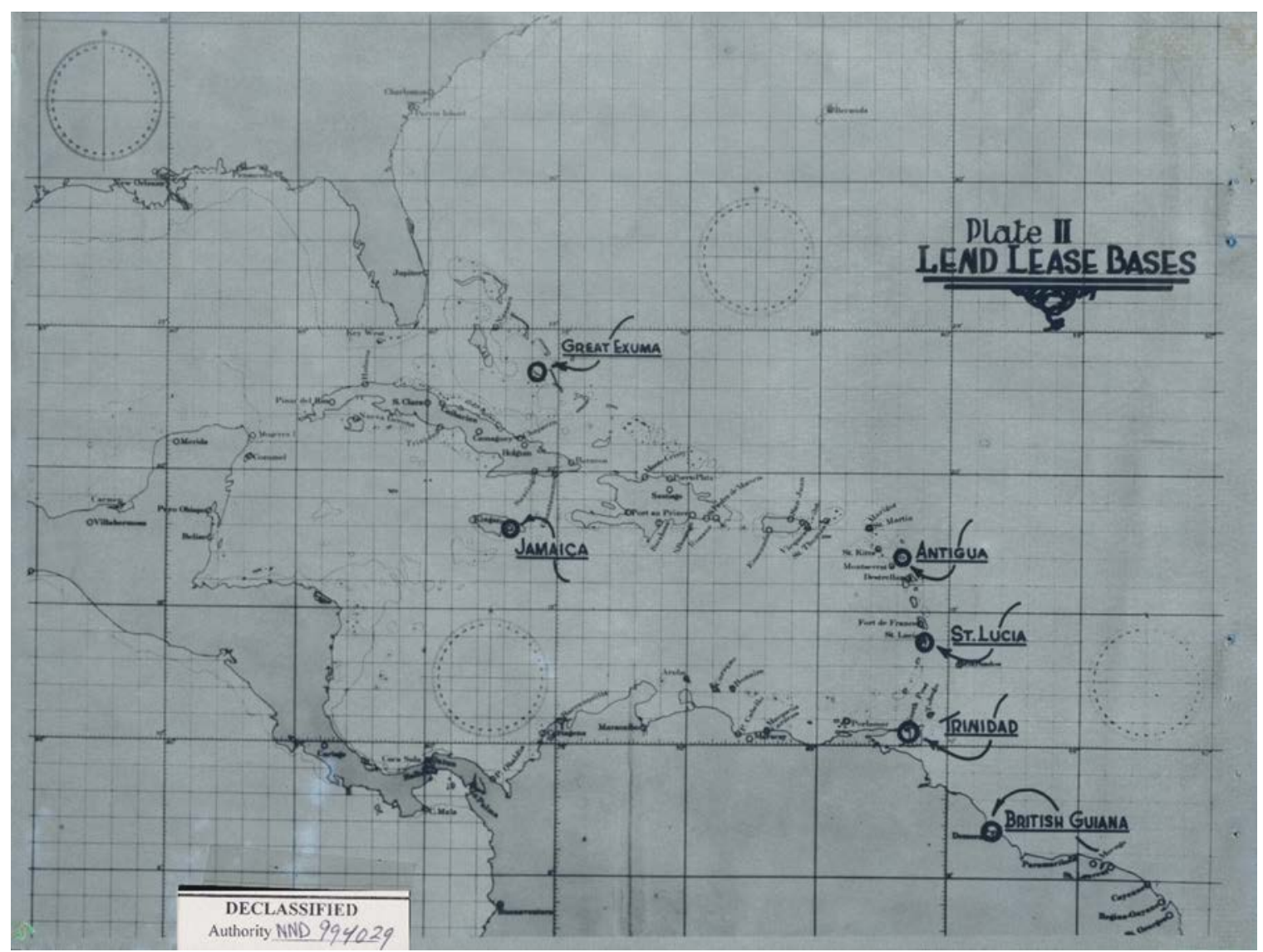

FIGURE 3: Lend Lease Bases.

Source: An Administrative History of the Caribbean Sea Frontier, RG 548, Stack Area B190, Row 1, Box 329, Container 314.7 Military Histories, p. 6.

78. History of the Command, 5. 
The Roosevelt Administration established the Caribbean Defense Command in the hopes of not only defending the waterways, but of establishing a base from which American power could be projected throughout the region so as to deter any possible hostility. Establishing such a command proved no easy feat. No such structure had ever been attempted before, and inter-service conflicts and competition had been accepted as a common fact of life in military circles. Indeed, the Navy's resistance to having a flag officer (general officer) assigned to the command delayed their full integration into the structure until $1942 .{ }^{79}$ The announcement in early 1941 of the creation of the Caribbean Defense Command simply referred to it as a national defense organization for "those islands in and bordering on the Caribbean sea, all such parts of French Guiana, Venezuela, Colombia, Ecuador, and Central America less Mexico and the seas adjacent thereto as may be required for Army and Navy operations.” This centralized military command was to be the "number one outpost of the United States... and directly controlling all sea lane access to the Mexican gulf frontier on the southeast.” It was tasked with guarding the Panama Canal which was simply described as "the vital artificial waterway connecting the two oceans.” By some accounts however, the goal was effectively converting Caribbean waters into an American "Mare Nostrum." 80 Existing plans assumed that any such endeavor would include the help from European and Latin American partner nations in securing additional outposts to supplement the

79. Headquarters and Staff, Caribbean Defense Command. Internal CDC Report, January 30, 1946, SOUTHCOM Archives, “CMH Caribbean Defense Command 08.02.8 AC, C1.” (Hereafter cited as Headquarters and Staff, CDC.)

80. History of the Command, 1. 
ones already established. ${ }^{81}$ Shortly before U.S. entry into the war, the $10^{\text {th }}$ Naval District was converted into the Caribbean Naval Coastal Frontier and separated into three sectors: Guantanamo, Puerto Rico, and Trinidad (see Figure 4).

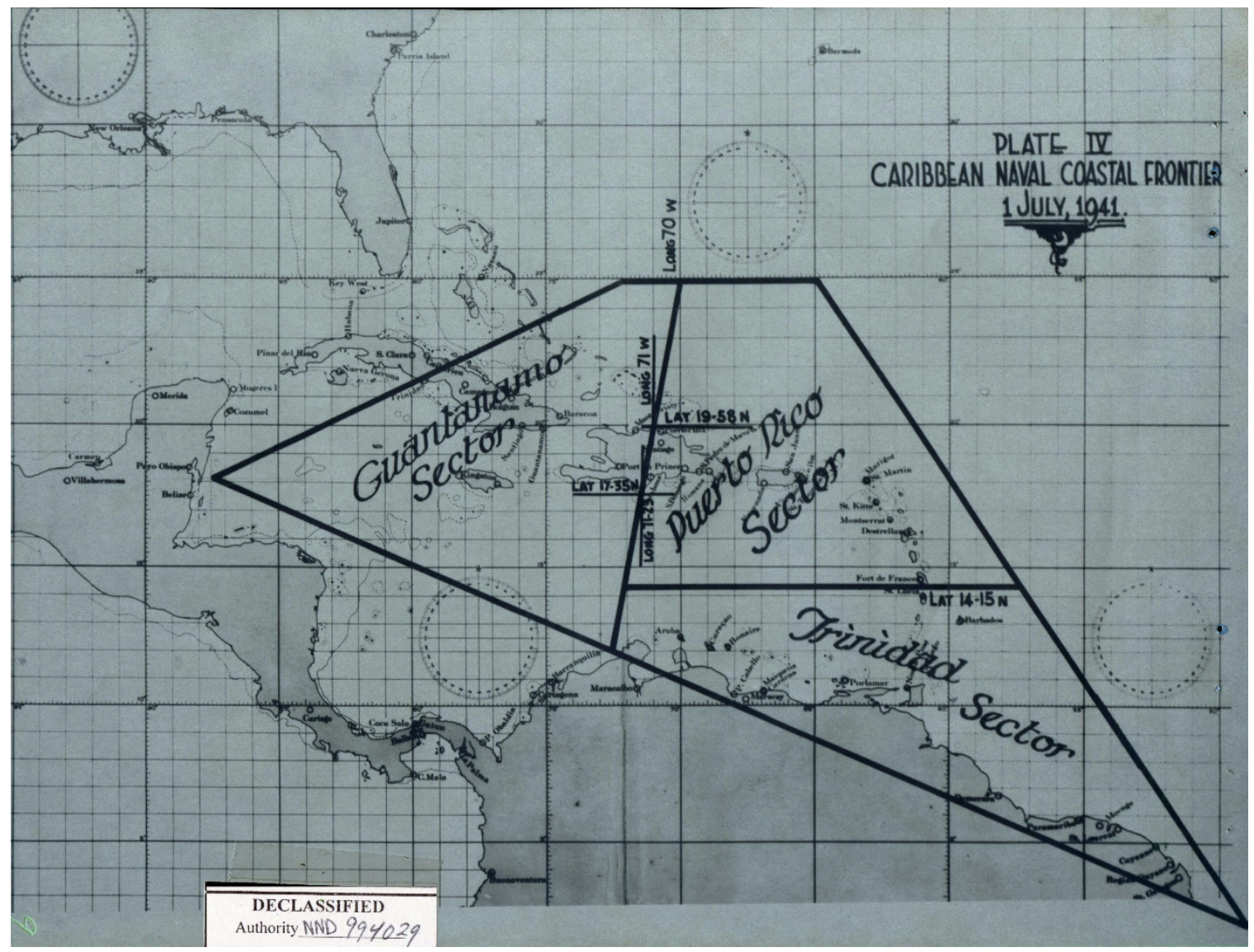

FIGURE 4: The Caribbean Naval Coastal Frontier on 1 July 1941.

Source: An Administrative History of the Caribbean Sea Frontier, RG 548, Stack Area B190, Row 1, Box 329, Container 314.7 Military Histories, p. 9.

By the time the Caribbean Defense Command was activated, the war had already been going on in Europe for sixteen months. In the time that the United States spent preparing for a possible entry into the war, most of Europe had capitulated to the German and Italian armies. Japan had joined the Axis in September 1940 which had virtually

81. History of the Command, 2-3. 
guaranteed that U.S. entry into the war would see Americans fighting on two fronts. Ironically, the increased danger had not been detrimental to the war effort. In fact, shortly before the attack on Pearl Harbor, U.S. public opinion had already begun to shift from strongly opposing any entry into war to grudgingly considering the U.S.' eventual entry into the war inevitable. Popular opinion had also translated into increased legislative support to prepare to meet the danger. ${ }^{82}$

The most immediate threats to the Canal were perceived as being sabotage, short duration carrier based air raids, and possible tactical incursions. ${ }^{83}$ Bombardment from the sea, or attacks from land by large expeditionary forces seemed improbable. It was believed projection of force should serve as a deterrent to the more likely forms of attack. Due to the lack of air assets in the region and the aviation technology of the day however, any defensive plans needed to assume that there would be no quick reinforcements from the United States to assist the Canal Zone should the situation turn dire, as even the fastest response would still leave the Zone to fend for itself for a protracted amount of time. This meant that plans had to be prepared before entering into any conflict, and had to assume any defense needed to be mounted by the troops on the ground with little or no relief. ${ }^{84}$

82. History of the Command, 7-8.

83. F.M. Andrews, Commanding General, Headquarters Caribbean Defense Command. Memorandum for the Secretary of War, March 12, 1942, RG 548, Stack B190, Row 1, Compartment 22, Box 305, Folder 376.21, Unity of Command.

84. History of the Command, 13. 
Early assessments suggested that though a direct invasion by Axis forces was unlikely, the use of submarine warfare to disrupt shipping and possibly threaten the Canal itself was a real threat as long as control over the Atlantic was not definitely settled. ${ }^{85}$ It was supposed, however, that U.S. armed forces would need to be used to assist the American republics to deal with subversive groups sympathetic to the Axis. This threat seemed serious enough that during the bi-lateral military staff conversations in the fall of 1940, the United States had agreed to provide support to these governments in resisting any such attempts. ${ }^{86}$ The need for unity of command under the circumstances was undeniable, as was the need to establish a unified command in a central area within the region itself. The Panama Canal Zone was chosen as the location for the command not only for its strategic significance, but with an eye toward establishing easy and regular contact with representatives from the southern republics. ${ }^{87}$

The process of running the Caribbean Defense Command was a particularly complex one, made even more so by the already complicated relationship between the military in the Canal Zone and the nation of Panama. During the construction of the Canal, after losing several key figures, President Theodore Roosevelt had decided on putting Lieutenant Colonel George Goethals, a member of the Army Corps of Engineers in charge of the project. Aside from the obvious experience Goethals had with creating and maintaining waterways, his position in active service for the Army meant that he

85. Proposed Outline, 1946, 11.

86. History of the Command, 5.

87. Headquarters and Staff, CDC, 8. 
could not simply quit his job the way the previous two head engineers had, but would have to remain at his post until recalled by the President. ${ }^{88}$ This move set a precedent for the governor of the Canal Zone to traditionally be a member of the Army.

The establishment of the Caribbean Defense Command threw a new wrinkle into this arrangement, as the commanding general of the Caribbean Defense Command needed unity of command in order to fulfill his duties. Because of the way the Caribbean Defense Command had been established however, the commander enjoyed unity of command, where it related to the actual Canal Zone, only in his capacity as commander of the Panama Canal Department, and not by virtue of his position as commander of the Caribbean Defense Command. Though in many cases, this was a "distinction without a difference," it began to cause several unexpected consequences as the war moved on due to the regimented nature of military operations. In particular, though the Caribbean Defense Command commander was nominally in charge of the Antilles Department, it meant that his dealings with this department could only be done through Caribbean Defense Command personnel instead of the more numerous Canal Zone personnel, causing manpower problems as the number of troops was reduced toward the end of the war. ${ }^{89}$ Unity of command had already been identified as a major contributor in the success of the Caribbean Defense Command in maintaining security over the region, and discussions were ongoing in maintaining the status quo after the war was over. In fact, in

88. Hoffman, Panama Canal, 12.

89. Major General J.L. Homer to Commanding General, Panama Canal Department, November 1, 1945. Internal CDC Memorandum, RG 548, UD, Entry 3, Box 90. 
a detailed discussion of the issue which attempted to list advantages and disadvantages of maintaining or expanding the Caribbean Defense Command structure after the war, the only disadvantage listed by the study was the possible resentment it might cause among the Panamanian people who were "suspicious and resentful of military domination." 90

Not surprisingly, the first year of operation of the Caribbean Defense Command was the most hectic, yet in a way, also the most successful. Although countless logistical challenges had to be met, the very quick establishment of a functioning command structure allowed the Caribbean Defense Command to set the precedent for the viability of such an enterprise. The first year was also one of increasing growth and staffingbecause as the United States quickly began gearing up for total war, the CDC was initially given as much support as possible.

90. Staff Study on Unity of Command-Panama Canal Department, September 8, 1945. Memorandum to Commanding General, Panama Canal Department, RG 548, UD Entry 3, Box 90. 


\section{CHAPTER 3: 1942, Rapid Growth}

1942 was arguably the busiest year for the Caribbean Defense Command and its assigned area of responsibility as an active theater of war. Although defense of the Canal remained the top priority for the Command, the need to protect both military and commercial shipping became a major concern around this time. Although the war was initially understood to be against Japan, the command was notified via Official Telegraph on December 11, 1941 that the United States was also at war with Germany and Italy. ${ }^{91}$ This meant that the German U-Boats that were known to be in the region were now fair targets, but also that they would likely begin hostilities. By late 1941, enemy submarines had been forced away from the European Coastal Waters by extensive bombardment air patrols and were seeking targets in new fields of attack. The amount of supplies and raw materials from South America which passed through the Canal was a temptingly underdefended target. Upon U.S. entry into the war, German submarine packs began infiltrating sea lanes along the eastern U.S. and Caribbean region, which proved to be easy targets. In 1941, one in five ships was lost to enemy submarines in the Caribbean. German submarine activity became particularly prevalent in the “Trinidad sector," which remained a weak link in the chain of defense of the region. ${ }^{92}$

Fortunately, decision makers in the United States had anticipated this possibility. From 1940 to December 7, 1941, preparations and plans had already been made for

91. GHQ Army War College, Washington DC to U.S. Caribbean Defense Command. Official Telegram, December 11, 1941, RG 548, Box 120, Stack 382.2-1.

92. Evans, Anti-Submarine Activities, 37. 
foreseeable action or threat against the Canal itself. ${ }^{93}$ Plans for Canal defense had not however, extended to defense of the entire region, so the dual assignment of the Caribbean Defense Command had not been as extensively planned out as Canal defense strategies. The lead up to the U.S. entry into the war further complicated the logistical situation by giving the United States control over the British Caribbean bases which it had received in exchange for war matériel (the Lend-Lease bases). The acquisition of new bases added to the possible defensive positions which could be used, but also became a major burden on the already limited resources afforded to the Command. Supplying such bases was a major logistical impairment, and manning them was equally difficult due to standard military rotation cycles, where most CDC assignments were less than a year in length. ${ }^{94}$ Moreover, the United States was not initially prepared to deal with an opponent pressing aggressive submarine attacks, and in many cases the Command had to learn as it went along and rely on the extensive experience of its European partners, particularly Britain in dealing with such assaults.

Following a brazen attack (described in more detail later) which caught the region by surprise, the Command also had to take into account not only military matters, but matters of international politics. The attack, though relatively insignificant when compared to the kind of violence being experienced in the European and African continents, seemed to shake the entire region and ultimately influenced the creation of stronger ties between the CDC and the local governments. This aided in the mission of

93. Evans, Anti-Submarine Activities, 11.

94. Headquarters and Staff, CDC, 19. 
keeping Axis influence from reaching the Western Hemisphere, and diminishing it where it already existed. The idea of an Axis presence in the region was also of major concern to the United States, and to the CDC. Throughout 1942, it became clear that Axis influence had indeed extended to the region, though not necessarily to the strength that many had initially feared. The clear signs of existing Axis activity throughout South America only helped to increase the tension within the theater and continued to be a source of concern to the Command until late in the war. In early 1942, the three sectors that made up the Caribbean Sea Frontier were once again redrawn to more or less the shape they would maintain through the end of the war (see Figure 5).

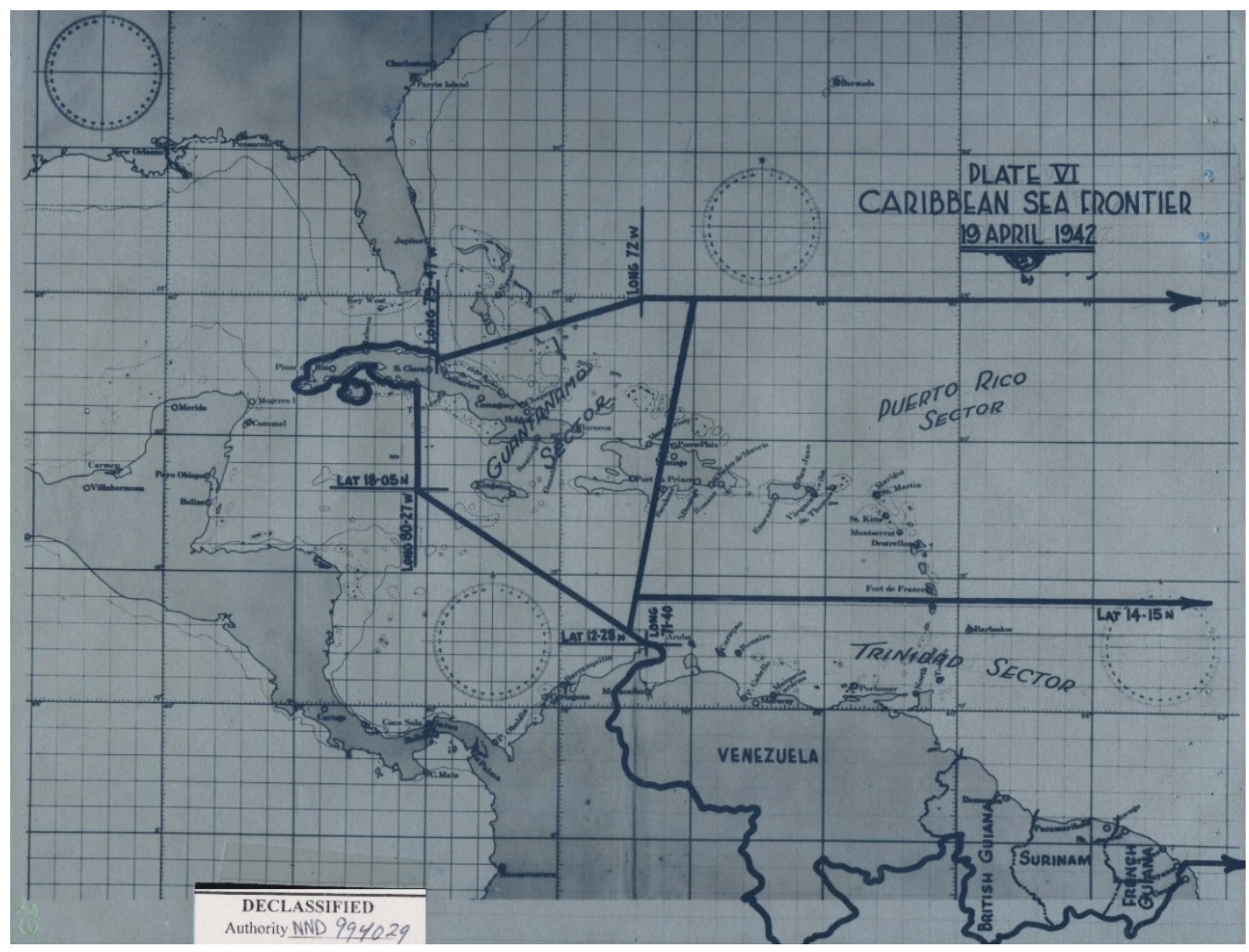

FIGURE 5: The Caribbean Sea Frontier, 19 April 1942.

Source: An Administrative History of the Caribbean Sea Frontier, RG 548, Stack Area B190, Row 1, Box 329, Container 314.7 Military Histories, p. 23. 
The year 1942 proved to be a high point for tension and activity throughout the region, and for the Command. Developments during this year established several trends that would help define the Command going forward. On a positive side these trends included increased unity of command among joint forces, increased professionalism in handling of the submarine threat, improved training programs, and increasingly positive relations with the other nations of the region. Several negative patterns also emerged, however, including such problems as continued difficulty in inter-service cooperation, a continuing though eventually diminishing threat of losses due to enemy action, and more importantly, a continued shortage of men and matériel which would hamper the command throughout its existence. The latter of these also led to a pattern of continuous change in tactics and organization to overcome shortages and deficiencies which made for a lack of consistency in operational procedures. Ironically, by the end of the year, the successes of the command along with positive developments in the war abroad actually led to the realization that the Command had to be reduced even further in personnel, which would be a process that would take up the initial portions of the following year. Toward the end of 1942, the Command experienced its first change of command, and the new commander would face significantly different challenges than his predecessor had.

The United States' rather abrupt entry into the war following the Pearl Harbor attack led to the activation of all the initial plans for defense of the Canal, and for the activation of the Caribbean Defense Command into proper war footing. Although not universal, support for the U.S. war effort was initially very high throughout the region. As early as December 7, 1941, Nicaragua became the first Central American nation to offer assistance by placing all their territory including land, water, and air at the service 
of the United States for as long as conflict between the United States and the Axis existed. Managua and Puerto Cabezas became the first airports operated by U.S. army personnel for use by U.S. aircraft. ${ }^{95}$ Though few expected a major land or sea invasion into the region, it was considered possible that Axis forces might decide to attack the Canal or the region through the use of infiltrators or other subversive tactics, as well as using more discreet military assets such as submarines. The Trinidad sector was eventually revealed to be one of the major weaknesses in the anti-submarine program and losses increased to one in four in this region. ${ }^{96}$

The very different relationships the United States enjoyed with the governments of the region played a big part in the CDC's ability to deal with such threats. British possessions were much easier to deal with when it came to possible espionage activity. One possible leakage incident, for instance, was dealt with early on by instituting a strong censorship program after which there were no further events. Unfortunately, relations were not as good in other areas. Continuing animosity toward U.S. personnel following racial incidents in Toledo, Brazil early in the war forced the U.S. War Department -which was attempting to censor mail going to and from U.S. personnel in the region-- to forego using local postal services and use U.S. Army mail exclusively. Though this proved to be an effective method to avoid leakages, it was an additional burden on an already stretched military bureaucracy. More troubling than any of these, however, was the situation of possible collaboration by subversive elements in the Trinidad sector

95. Evans, Anti-Submarine Activities, 44.

96. Evans, Anti-Submarine Activities, 37. 
which included French Guiana. The Governor of French Guiana was suspected of furnishing goatskins full of oil to use in making diversionary oil slicks for hiding German U-Boats, though military Intelligence was never able to substantiate this assertion. With Spain neutral during the war, though suspected of Axis sympathies, Spanish ships were also suspected of refueling German Submarines due to their continuous suspicious and erratic behavior in the region. ${ }^{97}$

Overall support for the United States within the region had been strong since the Pearl Harbor Attack, but as with all alliances, there were gaps. In January 1942, an emergency inter-American meeting had been held in Rio de Janeiro which had failed to establish a binding commitment and instead produced a weak resolution encouraging the various governments to break off relations with the Axis. At that time, it was simply not clear who would win the war, and several countries with traditionally strong ties to Germany and Italy (notably, Chile, Argentina, and to some extent Brazil) were reluctant to risk these relationships by taking the wrong side. ${ }^{98}$ Meanwhile, the increasingly bold Axis submarine attacks continued to be a growing concern throughout the region. Not only were they threatening military assets, but they were also causing a great deal of logistical damage to the war effort as well as loss of life. In June 1942, a Colombian Navy Schooner, the ARC Resolute was torpedoed, and the U-boat crew proceeded to

97. Evans, Anti-Submarine Activities, 94-97.

98. Bradly Lynn Coleman, Colombia and the United States: The Making of an Inter-American Alliance, 1939-1960 (Kent, Ohio: Kent State University Press, 2008), 12-13. 
machine-gun the survivors in the water. ${ }^{99}$ These attacks did not have to target military equipment directly in order to be effective. On August 1942, for instance, another Colombian Schooner was sunk by an Axis submarine preventing the Colombian Government from being able to transport goods between the mainland and their base at St. Andrews Archipelago. ${ }^{100}$ Brazil was similarly on the receiving end of Axis aggression which turned it decidedly toward the U.S. side by the end of the year. ${ }^{101}$ Panama, which had experienced a coup in October 1941 that brought a new president more agreeable to U.S. cooperation, had quickly declared war on the Axis and began detaining citizens of Axis nations. Similar actions along with a program of strict censorship and tight security virtually eliminated any Axis intelligence activities in Panama. ${ }^{102}$

Despite the overall trend toward pro-U.S. cooperation, several developments caused worries that collaboration with the Axis by populations within the region might continue. According to a May 1942 Report, a German U-boat was once spotted in the mouth of Rio Cassipore, Brazil, and the natives reported having sold supplies to a German at night. Such reports led the allies to believe there might be a hidden submarine base in the area. On Isla Maraca located in the mouth of Lake Maracaibo, Venezuela, signs of "probable Axis collaboration” were also noted. Other suspicious maritime

99. Coleman, Colombia and the United States, 12-13.

100. Evans, Anti-Submarine Activities, 49.

101. Coleman, Colombia and the United States, 12.

102. Conniff, Panama and the United States, 93. 
activity included a camouflaged airfield and coastal fires burning with no apparent reason, as well as sea planes attached to the French ship Jeanne D'arc which came and went quickly at suspicious times and intervals. There was also constant signaling via lights from small ships and the shore visible along the coast of Venezuela. ${ }^{103}$ The problem was not a purely foreign one, as a possible leakage incident involving U.S. Naval personnel was later suspected of having contributed to an attack on Aruba which had taken place the day the U.S. forces landed ashore. It was learned that the Merchant Marines had somehow become aware of the planned date for this landing. Though it was never definitively proven that this leakage incident had influenced the attack, it demonstrated the seriousness of even small information leakages. ${ }^{104}$

Paranoia had begun to grip the region leading to the responses to perceived or suspected enemy activity consuming valuable resources. Sometimes, the presence of real hostilities was enough to convince many that some of their more elaborate suspicions may be true. For instance, the same day as the first major attack in the region, information about refueling German submarines at Mara, French Guiana was received. Despite close air patrols, no definite information regarding a submarine base in French Guiana could be confirmed, but suspicions led the Department of War to request that Pan-Am commercial pilots flying nearby re-route to fly over the suspected area and report back. A month later, a U.S. observer was able to enter the area and reported back

103. Evans, Anti-Submarine Activities, 94.

104. Evans, Anti-Submarine Activities, 96. 
that there were no facilities available which could be used for such purposes. ${ }^{105}$ The whole affair had been a case of overblown suspicions in an understandably nervous region. Indeed, regardless of U.S. suspicions about Axis presence in the northern coast of South America, the United States was actually able to effectively use French Guiana airfields for Anti-submarine activities. ${ }^{106}$ More importantly however, the initial attacks helped illustrate just how vulnerable the region was in case of a coordinated attack and possibly helped dissuade some holdouts about the necessity of working with the United States. Immediately following the attacks, Peru had requested U.S. assistance in preventing similar attacks including a list of matériel so large that the CDC recommended use of the existing lend-lease program. ${ }^{107}$

The U.S. Anti-submarine program initially depended on British Royal Air Force (RAF) officers with experience in dealing with German U-Boats. From these experts, several important lessons were learned which would play a role in developing effective procedures. According to RAF plans that had been disseminated through the Department of the Navy, there were several different ways of dealing with submarines. Bombing submarines directly was only effective for subs which were visible on the surface or within fifteen seconds after submergence, but if release of the bomb did not show definite proof of destruction within a reasonable time, continued patrol of the area was still

105. Evans, Anti-Submarine Activities, 47.

106. Evans, Anti-Submarine Activities, 48.

107. Appendix 1; Summary of Staff Conversations with American Republics, August-October 1940, SOUTHCOM Archives, “CMH CDC 08.02.8 BA,” p. 1. 
recommended. According to RAF records such bombing proved $90 \%$ effective, and the continued patrolling from first contact to ten hours later proved successful in twenty two recorded cases with an average of four depth charges per kill. Alternatively, the record of dropping the bomb after fifteen seconds of submergence had only proven to be $1 \%$ effective, but the RAF had found that fixed cannons in aircraft had the ability to damage submarines to the extent that they had to go in for repairs. Such damage to craft which were at a distance from friendly bases placed them in hazardous conditions and left them vulnerable to attack. Front mounted guns on airplanes, however, were found to be even better offensive weapons. Such plans were dependent on having adequate numbers of bombs, planes, and ships disposable for the effort, which was not the case at the Caribbean Defense Command, so plans needed to do as good a job as possible with the existing resources. ${ }^{108}$

Partly due to these restrictions, it was decided that an Anti-submarine program could not solely attempt to find and destroy enemy submarines, as the relative ease with which these could avoid such efforts would render such an endeavor a waste of valuable resources. The overall plan then, also included ample use of coastal artillery. Aside from denying enemy surface craft approach, the purpose of coastal artillery placements was also to serve double duty and protect minefields as well. A Harbor Entrance Command Post (HECP) was established to give control of all passage to Army and Naval personnel through the Canal and its accessways. Some fixed harbor defense batteries were assigned dual duty of defending against motor torpedo boats and submarines.

108. Evans, Anti-Submarine Activities, 61-62. 
Islands along the Antilles were also garrisoned with 90mm (Anti-Aircraft) batteries in the dual role of anti-Aircraft and Anti-Submarine defense as part of the strengthening of the “steel ring” around the canal. ${ }^{109}$

The U.S. Navy was officially in charge of Anti-submarine operations and thus was in charge of anti-submarine training. The training took the form of having a friendly submarine simulate various submarine "signs" such as sending out an oil slick, travelling with a periscope just barely breaking the water, or submerging rapidly. These maneuvers were used to train anti-submarine personnel on what to look out for. Due to the standard rotation of personnel within the Command, this became routine training for incoming personnel. Despite training, however, the task of successfully identifying submarines based on such signs remained a difficult one, so a major point of training for incoming personnel was also knowing and identifying likely paths that submarines would take. ${ }^{110}$ All Caribbean Air Force Units had to submit anti-submarine reports to the Commander in Chief U.S. Fleet through the CDC. This included the Caribbean Coastal Air Force and Antilles Department. This coordination had the effect of making common use of methods of strategy by compiling information from all allied nations. ${ }^{111}$ It was also however a possible bottleneck in the flow of information which would have unexpected consequences on at least one occasion.

109. Evans, Anti-Submarine Activities, 71.

110. Evans, Anti-Submarine Activities, 70.

111. Evans, Anti-Submarine Activities, 60. 
All the preparations leading to establishing an effective steel ring against Axis submarines were in place surprisingly quickly after the U.S. entry into the war, a testament to the quality of the pre-war planning and to the efficiency of those involved. By December 20, 1941, General Johnson had asked that bombers being assigned to the Command include as many large B24s as possible in order to perform deep sea patrol work "necessitated by shortage of naval patrol bombers," and on December 22, 1941, the Panama Air Task Force was created under the supervision of the CDC. ${ }^{112}$ Shortages in the number of available planes, however, made it clear that the well-designed plans that had been created for the defense of the command before the war did not stand a reasonable likelihood of being implemented.

On January 4, 1942, bomber command submitted a much more modest plan based on available equipment. These revised plans requested patrolling a distance of only 600 miles from Talara in north-western Peru to the Galapagos Islands and back. This would consist of B-17s based in Talara and B-17s from Guatemala conducting two patrols per day. There would be three such patrols requiring 37 B-17s and 14 PBYs for a total of 51 vessels in all, but if these were to continue for a prolonged period it would require three times as many planes. There would be no night-time coverage but at dusk an estimated sweep of 15 planes at Talara, 10 in Guatemala, and 14 in Galapagos would increase the required planes for continuous operations. Both the new plans and the people implementing them implicitly accepted that there would be holes in coverage until more

112. Evans, Anti-Submarine Activities, 32-33. 
planes became available. ${ }^{113}$ In early 1942, blackout operations were put into effect in the Trinidad sector and anti-aircraft and harbor defenses were manned around the clock and “close coordination of civil and military defense measures was affected.” Radar stations were established. Coverage grew increasingly effective until submarine activity dissipated. All these measures were by necessity kept secret. ${ }^{114}$

On January 17,1942 , Flights B and C of the $59^{\text {th }}$ Bombardment squadron began their assignment in Aruba and Curaçao using six of the available eleven A-20As-for the double duty of submarine patrol and escort duty. Due to the inadequacy of naval assets in the region, a recommendation was made to send the $25^{\text {th }}$ Bomb Group and 27th Recon squadron to Panama to increase their capabilities. This was not the only instance of resources being shifted around. Shortly after the attack on Aruba, the Puerto Rico, $3^{\text {rd }}$ pursuit squadron sent planes there to augment their forces after the attack. ${ }^{115}$

In one of the earliest examples of the joint inter-service nature that would define the command, in February 1942, HECP installations were approved and installed so that Navy forces could operate jointly with the Army. General Marshall had actually approved these installations back on June 23, 1941, but they were not installed until after the U.S. entry into the war. The purpose of HECP was to act as a localized intelligence section to disseminate information of activities in defense sea areas and take decisive

113. Evans, Anti-Submarine Activities, 33-35.

114. Evans, Anti-Submarine Activities, 79.

115. Evans, Anti-Submarine Activities, 51-52. 
action to "operate elements of harbor defense against the enemy in those defensive coastal areas.” CDC leadership came to realize the necessity of having American Garrisons to protect unprotected harbors in the Caribbean as sinkings by submarines increased. These parts included Puerto Barios, Guatemala, where the army Air Forces set up a field along the route from Miami to Panama. ${ }^{116}$ For the most part, until that first major series of attacks, the situation remained tense, but there was little actual activity. An incident on February 7, 1942 was typical of the happenings, when an enemy submarine was spotted but upon further investigation it turned out to be a false alarm. On February 13, 1942, U.S. bombers were sent to attack a submarine being engaged by the U.S. Destroyer Goff, northeast of Jamaica but were unable to find it. ${ }^{117}$ Nevertheless, planners believed that a major rise in activity was likely, and for the most part they proved to be justified in this assessment.

The first major hostile operation of the war within the CDC AOR occurred on February 16, 1942 and despite the relative insignificance of the action when compared to the entirety of the war effort, it made a lasting impression in the region. At 0711 hours, a visiting staff officer in Aruba reported enemy submarine action causing an antisubmarine patrol to be dispatched to the area. The SS Mongagus was also reported as being fired on, and Axis submarines attacked merchant ships and shelled a refinery on Aruba. A U-Boat fired a torpedo into the U.S.S Perdernales and SS Orangestad while they were at anchor in San Nicolas Harbor. Both ships were lost. Shelling of the refinery

116. Evans, Anti-Submarine Activities, 71-72.

117. Evans, Anti-Submarine Activities, 59-60. 
also hit a nearby school but fortunately caused no loss of life. As there was no way to tell if this was a coordinated attack or the work of a single U-Boat, the response was understandably ineffective. By the time the B18As were sent out, they sighted a submarine but dropped no bombs. Another submarine was bombed but damage was estimated as being negligible. The final summary of the attack described the biggest weakness in the response as being the lack of notification. The submarine doing the shelling would have been an easy target to retaliate against with enough time to respond. Lack of depth charges was also an issue as the planes were forced to rely on 300lb demolition bombs which were not designed to attack submarines. ${ }^{118}$

The following day, a submarine, possibly the same one as from the previous day's attack once again surfaced near the airport and it once again submerged immediately. Speculation was that it might be trying to gather information on the aircraft in the field to relay back to their command. Shipping dropped "noticeably" after this second incident, demonstrating the amount of damage that a single submarine could conceivably accomplish. The entire island of Aruba was completely blacked out though there were reports of suspicious lights spotted intermittently from prominent peaks. The lights were speculated to be either Axis agents, infiltrators, or fifth columnists sending signals. One morning a few days later, while still reeling from the previous activities, shell fire was heard over the Largo refinery. It was later determined that these were actually fired from the U.S. Destroyer Winslow. The shelling caused very little damage but three planes took

118. Evans, Anti-Submarine Activities, 38-40. 
off to cover the area and bombed an enemy submarine they spotted, though there was no way of knowing how much damage they caused. ${ }^{119}$

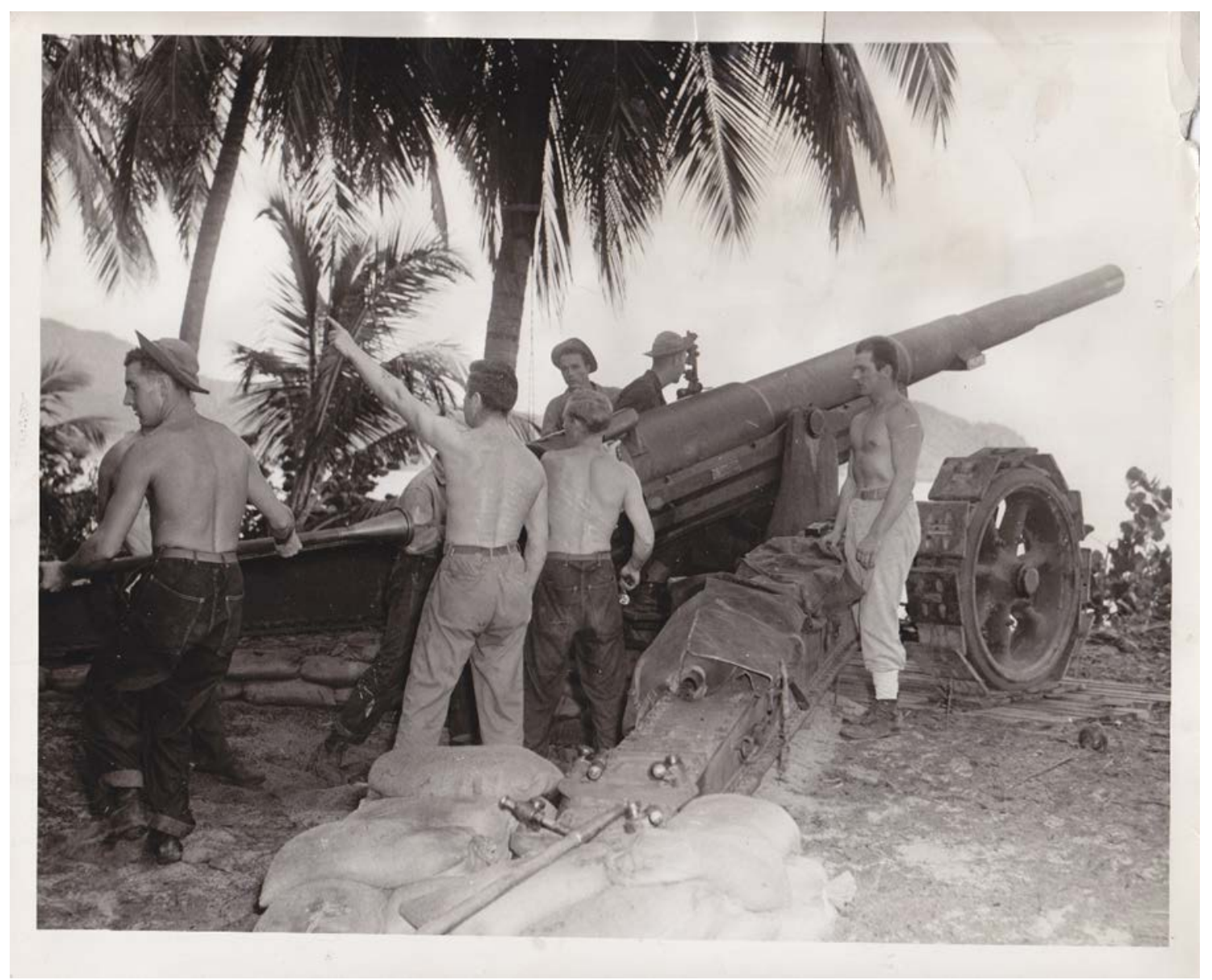

FIGURE 6: U.S. Personnel manning Coastal Artillery.

Source: Pictorial Archives of United States Southern Command, SOUTHCOM Archives.

Following the Aruba attack, the CDC conducted an extensive study of the coastal defenses which brought to light a longstanding debate regarding placing heavy armaments at the bases of both canal harbors (upgrading existing guns). One difficulty with creating coastal artillery positions was that these were in hard to reach tropical locations as seen in Figure 6. The need to have these positions continuously manned

119. Evans, Anti-Submarine Activities, 41-42. 
would mean exposing U.S. service personnel to extreme conditions in remote areas for prolonged periods of time. For this reason it was preferred to put coastal artillery positions in areas that were either closer to civilization or easily reachable. Upon examination of these plans, engineering reports suggested that the rocks in many of the proposed areas were so unstable that creating the necessary fortifications would be prohibitively expensive as it would require not only building the defenses, but also facilities for stationing personnel around the clock. Eventually a suggestion to put large 37mm Anti-aircraft guns in place at the gate ends or on nearby barges at the breakwaters entrance was approved, but it was contingent on availability.

Another problem encountered dealt with the vast difference in terrain between the two different coasts. The Pacific side of the Canal was geologically very different from the Atlantic side and needed vastly different solutions to the same problem. On the Pacific side, the existing minefield caused the problem of attempting to deploy coastal defenses from a great distance. Large $75 \mathrm{~mm}$ guns were recommended for protection. ${ }^{120}$

Attacks on merchant vessels continued following these incidents. After the war it was learned that the successes by the Axis in early incursions had led to an intensification of submarine activity in the area. In short, the uncoordinated and weak initial response had acted as an encouragement to the enemy, and it was later estimated that there were only eight to ten enemy submarines operating in the area. Ironically, this uptick in activity laid the groundwork for its eventual diminution. The initial attacks, as noted,

120. Evans, Anti-Submarine Activities, 80-81. 
rattled the region enough to help consolidate cooperation with the United States by several holdouts in Latin America. Venezuela for instance, immediately granted the United States informal permission to use their airfields and bases for use against enemy submarines in Aruba and Curaçao, and Dutch authorities allowed their forces to be placed under U.S. control It also forced the CDC to increase their coordination with their more remote subordinate commands and soon thereafter, the U.S. Army and Navy "effected a unity of command under the senior naval officer for all the United States forces in the Aruba Curaçao Area.”121

Submarine activity was by far the biggest concern toward the beginning of 1942, but concerted enemy action was also a big fear. A memorandum dated February 3 from Colonel William Walker outlined a theoretical attack by a Japanese task force consisting of aircraft carriers, cruisers, destroyers, and submarines. The final assessment of the exercise was simply that the Canal and its waterways were susceptible to attack, and that it was necessary to bring in both additional heavy bombers and experienced personnel to operate them. ${ }^{122}$ By February 28, 1942, submarine activity had grown to the point that $10 \%$ of shallow draft tankers operating out of Maracaibo, Venezuela to Aruba had been sunk. It became clear that neither overflights to engage enemy subs, nor coastal defenses would be enough to deal with the continued attacks, so a regular convoy system with routed traffic lanes near coasts of Central America was inaugurated to help protect

121. Evans, Anti-Submarine Activities, 42.

122. Colonel William Walker to General Malony, Memorandum regarding CDC Concurrences, February 3, 1941, RG 548, Entry 57A G.H.Q., U.S. Army CDC Box 137. 
Caribbean shipping. ${ }^{123}$ The convoy system sought to make efficient use of planes available by assigning them dual duty of convoy protection and submarine search. Their radius of coverage was five to twenty-five miles from the center of the ship formation, depending on visibility, each plane maintaining a 1500 yard distance unless recognition signals were exchanged. This latter precaution was to ensure protection against hostile aircraft which might accompany a submarine pack. Convoy planes maintained various altitudes, both to prevent collision and to allow the pilot to give his attention to submarine search instead of worrying about the placements of other nearby aircraft. The last patrol before nightfall covered a radius of thirty miles with special attention given to the flanks and areas astern. ${ }^{124}$

The coastal defenses were also determined to be insufficient for the actual threat posed by the subs, leading to efforts to increase the coastal defenses to areas not directly controlled by the United States. Fortunately, the newfound cooperation brought about by increased sub activity was a major aid in this respect. On March 11,1942, Major P.W. Edwards, an assistant to the Assistant Chief of Staff G3, went to Guatemala to make a study of defense needs there. Following the visit, he recommended a minimum of two batteries of 75mm guns, three seacoast search lights, and eight machine guns (four for each battery) all with the necessary ammunition and wire communications. He added provisions for additional 155MM gun batteries should shipping in the area increase. Interestingly, Edwards also recommended that Guatemala participate in the defense of

123. Evans, Anti-Submarine Activities, 52.

124. Evans, Anti-Submarine Activities, 57. 
this portion of their territory themselves, indicating not only a willingness by the United States to rely on its newfound partners, but also a surprising degree of confidence in their abilities. $^{125}$

There were still several growing pains ranging from both lack of material and lack of coordination and training. One problem was the constant reworking of responsibilities for portions of the air campaign based on available resources and mixed abilities. On April 10, 1942, for instance, a special Task Force was established to patrol between Cape Mala and the northern limit of the Gulf of Panama and Jaque point at the southern limit, but it eventually had to be discontinued at General Andrew's decision in favor of the Panama Air Task Force organization which proved to be better suited to this. This small logistical issue, paled in comparison to more serious training issues. Illustrative of these issues was an incident occurring on April 20, 1942 when the U.S. Submarine Flying Fish was attacked by a plane of the $74^{\text {th }}$ Bombardment Squadron based in Guatemala which had gone on a regular anti-submarine patrol before receiving reports of friendly submarines in the area. Upon spotting the Flying Fish, and with no word of any friendly submarine movements, the pilot attacked. Fortunately, the attack was unsuccessful and “little or no damage was done.” However, the incident helped to stress to pilots the importance of strict adherence to standard procedures, and to the Navy the importance of being prompt in reporting of friendly vessels movements. ${ }^{126}$ It may also have illustrated how ineffective many such attacks could be. Though largely dealt with through training,

125. Evans, Anti-Submarine Activities, 72-73.

126. Evans, Anti-Submarine Activities, 58. 
friendly fire incidents continued throughout 1942. As late as August 21, the S-17, an old World War I vintage Submarine surfaced in the outer harbor of Balboa but failed to display colors as required in unrestricted waters. The command officer of the $45^{\text {th }}$ Bombardment Squadron dropped four bombs which straddled the submarine causing damage that took seven days of repair work to fix. A subsequent investigation cited the submarine for carelessness, and the Air Corps personnel for being "over-eager" in attacking the submarine too fast without allowing it time to recognize their mistake and fly their colors. ${ }^{127}$

From March to June 1942, 173 ships were sunk in the Caribbean by German submarines with the rate increasing until August 1942. These ranged from merchant to military vessels. By this point, the Command was becoming more aggressive and effective in their defense of the region. The increased effectiveness toward the end of the year along with positive turns of events in the war caused the submarine attacks to begin to taper off. ${ }^{128}$ Axis U-boat activity was highest in the Trinidad sector making this the weak link in the "steel ring" of protection around the canal. The area was both physically and politically complicated. It "dipped into and embedded itself into South America," but also required coordination with four different nations due to encompassing British, French, Dutch, and Venezuelan land and waters. Additionally, due to the different terrains that needed to be covered, protection of the areas had to be distributed among

127. Evans, Anti-Submarine Activities, 58.

128. Evans, Anti-Submarine Activities, 63-64. 
several different service groups (Army for land protection, Army Air Corps for airfields, and Navy for the waterways). ${ }^{129}$

At around the same time that the command's effectiveness was finally making a dent in the continued submarine attacks, General Marshall directed the organization of the $1^{\text {st }}$ anti-submarine air command, whose mission was to destroy hostile submarines. ${ }^{130}$ This would be controlled by the War Department and would be stationed first to patrol the Atlantic coastal waters, especially those of the Gulf of Mexico. There were problems in setting it up however, which would not be resolved until March 1943 following a conference in Miami with representatives from Antisubmarine Command, WDGS, $7^{\text {th }}$ Naval District, Operations Division, CDC, and the Caribbean Sea frontier which resulted in the establishment of San Julian and San Antonio bases as the center of the antisubmarine command's activities in the Gulf. ${ }^{131}$ Nevertheless, that same month, a possible submarine sighting rattled a convoy when an escort pilot reported observing an unidentified submarine towing a dinghy which was speculated to be used to transport submarine personnel ashore. ${ }^{132}$ Upon further analysis, absence of any definite

129. Evans, Anti-Submarine Activities, 76.

130. General Marshall actually directed the organization of the $1^{\text {st }}$ anti-submarine air command in September of 1942, just after Axis submarine attacks had reached their peak and were beginning to taper off. The planning for this however had begun while the submarine threat was still increasing.

131. Evans, Anti-Submarine Activities, 55.

132. J.D. Stapp, Air Combat Intelligence Officer to Commanding Officer, Patrol Squadron Eighty three. Report of Submarine sighting of March 27, 1943. U.S. National Archives Record Group 38, Fourth Fleet, Box 42. 
identification or physical evidence led to questions about the reliability of the report, pointing to the continuing paranoia regarding such activity that still existed in the region.

Unity of command continued to be a major problem even after this was settled as naval anti-Submarine units within the Caribbean Sea Frontier were under command of Commander Caribbean Naval Sea Frontier, not under the direct command of the Commander, CDC. This situation continued until July 1943, when the $10^{\text {th }}$ Fleet was established. ${ }^{133}$ Until this time, CDC responsibility was to provide Army air units on request to be used in joint operations. It was then determined by the Secretary of War that recon capabilities in the outer Atlantic were "meager" in comparison to those of the Pacific theater, which prompted LTG Andrews to recommend acquiring "bombardment aviation equipped with radar detector sets for the interception and destruction of all enemy naval vessels," to act as the primary weapon of opposition to any sea threat in the Caribbean. Military intelligence also demonstrated the need for additional coastal batteries in Venezuela but such were not received until much later (April 1943) as part of an anti-submarine defense armament arranged under lend-lease agreement. ${ }^{134}$

Nevertheless, anti-submarine assets continued to mount and by November 1942, a new sea plane base was partially completed at Cotrino, Nicaragua despite lacking any formal agreements signed prior to construction. It was garrisoned by a detachment of 185 men to guard against submarine bombardment, surface raid, or any other types of

133. Evans, Anti-Submarine Activities, 54.

134. Evans, Anti-Submarine Activities, 75. 
action. ${ }^{135}$ By this point however, submarine reports for the Caribbean area already showed an appreciable decline of hostile submarines present in the waters. Eight submarines were known to have been in the area, counting those entering and leaving the operational limits of the Caribbean Sea Frontier: four near Trinidad, one near Aruba, two near Puerto Rico, and one near Guantanamo. ${ }^{136}$

The ultimate expansion of the Caribbean Defense Command as originally planned, never fully developed. This was attributable partly to the Command's ability to, after a few fits and starts, effectively deal with the submarine threat to the region. Ironically the reduced submarine threat that these efforts had produced gave decision makers the impression that the region was not under heavy threat and this weighed in their funding and sourcing decisions in contrast to the very immediate needs of units operating elsewhere in the war. It also was due to the favorable turn in the war following the U.S. led invasion of Africa in 1942 (Operation Torch, November 8, 1942) which redefined the conflict and diminished the importance of the Caribbean theater. ${ }^{137}$ By the end of 1942, it had become apparent that CDC staff had to be reduced, and a new organizational chart with 100 less personnel was submitted (though it was not approved by the War Department until March 25, 1943). ${ }^{138}$ November 1942 also saw LTG George Brett succeed LTG Frank Andrews, who had led the command through its first volatile

135. Evans, Anti-Submarine Activities, 44.

136. Evans, Anti-Submarine Activities, 68.

137. Headquarters and Staff, CDC, 18.

138. Headquarters and Staff, CDC, 20. 
years. ${ }^{139}$ LTG Brett's tenure at the Caribbean Defense Command would prove to be quite different from that of his predecessor who had been mostly concerned with ramping up the command and bringing it to something approaching full capacity, while always fighting for additional resources in a resource limited atmosphere. Due to reductions in both manpower and activity, LTG Brett would spend much of his time working on political-military relations with Latin American nations. Ironically, this proved very fruitful in the long run. ${ }^{140}$

139. Headquarters and Staff, CDC, 21.

140. Headquarters and Staff, CDC, 22. 


\section{CHAPTER 4: 1943, Peaking and Reorganization}

When General George Brett succeeded General Andrews toward the end of 1942, he inherited a command that had grown quickly from its inception and was in many ways at its peak. Yet, by this time it was universally understood that the command would be changing significantly under its new commander. Diminishing Axis activity made it clear that the threat to the Caribbean region would be minimal and the likelihood of the war spreading to the AOR was minimal as well. Meanwhile, the progress of the war in Europe and Africa was putting a major strain on resources. Lack of activity in the Caribbean led to the Caribbean Defense Command being downgraded repeatedly and restructured several times throughout $1943 .{ }^{141}$

As part of these reorganizations, throughout 1943 to the first part of 1944, the Caribbean Defense Command's mission shifted, which inevitably led to increased chain of command issues. ${ }^{142}$ Due to force reductions, and partly due to his own character and preferences, the new commander spent much of his time working on political-military relations with Latin American nations rather than purely military issues. ${ }^{143}$ In the long run, Brett's assignment to the post proved to be a fruitful development for the command as the CDC would come to be seen as a useful venue for communications and interaction with the United States by its southern allies as well as U.S. planners.

141. History of the Command, 5.

142. Headquarters and Staff, CDC, 24.

143. Headquarters and Staff, CDC, 22. 
Of the four commanders that the Caribbean Defense Command had in its brief existence, General Brett was quite possibly the one most responsible for turning it into what it and its successor commands would eventually become- vehicles for diplomacy and military cooperation with the nations of their AOR. George Brett was an Army Air Officer and had experience with dealing with assorted personalities competing in different services in difficult circumstances and resource limited situations. Despite having once been described as “... a rather easy-going Air Force officer, who was probably a better flier than administrator," he eventually proved to be a rather gifted diplomat. ${ }^{144}$ More importantly, Brett had first-hand experience in dealing with larger than life personalities, personal egos, and political posturing, all of which would serve him well in the region. In fact, it was partly due to his experiences in such issues that he had ended up as Commander of the Caribbean Defense Command to begin with.

Brett's appointment to the Caribbean Defense Command came following some unpleasantness that occurred in the Pacific theater after he rather famously (and unintentionally) rankled one of the most enigmatic and storied officers in American history, General Douglas MacArthur. Brett was in command of U.S. forces in Australia when the Philippines had surrendered to the Japanese and Washington had ordered MacArthur to head to Australia to become Supreme Allied Commander in the Pacific. The order to evacuate the Philippines had personally riled MacArthur, who felt it gave the appearance that he had lost a battle, in his opinion through no fault of his own. Brett, 
as commander of U.S. forces in Australia would in effect be ceding his position as highest ranking officer in the region to MacArthur once the latter arrived. Unfortunately, he was also in charge of arranging MacArthur's transportation to Australia. Though not being directly told the true importance of the transport mission he was to arrange for reasons of security, Brett was savvy enough to figure out whose safety he was responsible for. Knowing that MacArthur was not fond of flying and would not ride in anything but the best aircraft, he tried to arrange for the best possible aircraft the Army had at their disposal, a B17 bomber. These were in short supply as few had made it back from Java, and the few new ones being sent from the United States were assigned to a Navy unit whose commander initially refused his request to borrow some for the mission.

Of the four B-17s Brett was able to secure to ferry MacArthur and his party (which included his family), two were laid out due to mechanical problems and were unable to make the trip, and one ran out of fuel midflight en-route to pick up MacArthur forcing the pilot to ditch and costing the life of two crewmembers. ${ }^{145}$ The single B-17 that arrived and was available to make the trip was an older, very worn unit with an inexperienced crew. MacArthur flat out refused to ride in the aircraft. The ever irascible MacArthur, already in a foul mood over being ordered to retreat, took personal offence and assumed animosity on Brett's part for being replaced as commander in Australia. Although four new B-17s were eventually secured for the flight, the damage had been done. Right before arriving in Melbourne, MacArthur had already sent a formal request to have Brett removed from the theater and took an early opportunity to disrespect Brett

145. Cox, Airpower Leadership, 43. 
by refusing to let him ride in the same vehicle and then refusing to see him for a meeting after keeping him waiting for quite a while. In fact, MacArthur did not meet Brett until eight days after arriving in Australia, which was rather unusual for a commander relieving another of command. ${ }^{146}$

General Richard K. Sutherland, MacArthur's Chief of Staff, was also not fond of Brett and endeavored to keep the animosity between the two going for many months. It did not help that Brett had made some poor choices in his attempts on who to court among the local Australian political elite. Trying to foresee future relations with the Australian government, Brett had openly courted some members of the Conservative Party which he believed would prevail in upcoming elections. When this did not happen, the members of the ruling party had then held some resentment toward him. Fortunately for Brett, General George Marshall, the Army Chief of Staff and a fellow VMI graduate, was a close friend of his and was reluctant to replace him. It was partly due to Marshall's influence that MacArthur and Sutherland had to tread carefully in replacing Brett.

Although MacArthur and Sutherland were eventually successful in getting Brett removed from the Pacific theater, it was done without any real suggestion that he had failed in his mission. In fact, though there had been some general dissatisfaction with Brett's often overcautious approach, even MacArthur admitted through all his complaints that Brett was "Brilliantly gifted” as well as being "Unquestionably highly qualified as an air technician and in air administrative duties of a productive or supply character; he is an

146. Cox, Airpower Leadership, 45-46. 
unusually hard worker...” ${ }^{147}$ The backhanded compliment of overly qualified praise was probably as far as MacArthur was likely to go. Upon Brett's recall to the United States, Sutherland signed a decoration certifying the award of the Silver Star by General MacArthur to George H. Brett, "For gallantry in action in air reconnaissance in the combat zone, Southwest Pacific Area, during the months of May, June and July, 1942." 148 Brett subsequently returned to the United States where he awaited either a new assignment, or possibly a court martial. General Marshall, however quickly put him at ease, and the military preference for not airing dirty laundry, especially in a time of war eventually won out, and Brett was informed that he would be taking over the Caribbean Defense Command. Before proceeding to the Caribbean Defense Command in late 1942, Brett began a public tour of the United States where he became something of a celebrity as a high ranking warrior returning home.

Brett assumed command at the height of the Caribbean Defense Command's buildup. Though he did have to deal with various logistical issues, his primary job was as Washington's representative to the governments of the region, where he traveled extensively. Brett was unusually well qualified to take over the Caribbean Defense Command. He was a close friend of General Andrews, meaning there would be no conflict between incoming and outgoing commanders as there had been with MacArthur. And Brett's close friendship with General Marshall and contacts in Latin America would serve him well throughout his command. Logistical issues aside, the fact that the

147. Cox, Airpower Leadership, 56-57.

148. Cox, Airpower Leadership, 62. 
Caribbean Defense Command was not currently an active theater of war was an

additional stroke of luck. Brett himself had a larger than life personality similar to that of MacArthur, though admittedly lacking MacArthur's hypersensitivity. He also seemed to inherently understand the importance of developing personal friendships with local leaders, which would serve him better in Latin America than it had in Australia. He had personally "adopted” a B-17B called the Swoose, as his own private transport plane. The Swoose would fly him around the AOR during most of his time as commander, and he was able to use it effectively as a means of propaganda allowing foreign leaders to travel with him, and reportedly even allowing the Presidents of Cuba and Nicaragua to fly as copilots during “good neighbor” visits. ${ }^{149}$

Almost immediately upon arriving at the Caribbean Defense Command, General Brett was faced with the type of bargaining and haggling for resources that would characterize a good part of his time there. This was indeed not all in the form of force reductions, but in actual loss of facilities. For instance, in a January 1943 memorandum, the commander of the Panama Sea Frontier agreed to the proposed elimination of the proposed Navy installations at Salinas and agreed to pass the recommendation on to the Department of the Navy. The recommendation had been initially made for the simple reason that only four squadrons had been assigned to this command (the Panama Sea

149. Cox, Airpower Leadership, 73. The Swoose would be slated for disposal after the war, but through the efforts of Colonel Frank Kurtz, who as a Captain had first selected it to serve as General Brett's transport, it was eventually transferred to the care of the National Museum of the United States Air Force where it is awaiting restoration. Kurtz, who was the Swoose's pilot throughout its career at the CDC, would later go on to name his daughter, actress Swoosie Kurtz in honor of the plane. For more information see, Herbert S. Brownstein, The Swoose: Odyssey of a B-17 (Washington, DC: Smithsonian Institution Press, 1993). 
Frontier) which was barely sufficient to man and equip all the existing bases, not to mention speculative ones that had not even been completed yet. ${ }^{150}$ Inherent in such reductions was the understanding that the war would proceed without them ever being needed. The lack of personnel was not solely noticed by Brett and his staff. On January 8, Major General H.C. Ingles of Army Staff had produced a major study on the organization of the Caribbean Theater and recommended among other things that the Caribbean Defense Command be discontinued altogether. ${ }^{151}$ On February 27, 1943, War Department Assistant Chief of Staff Thos T. Handy said to Brett that Ingles' suggestions had been received but could not be accepted in their entirety though he nonetheless acknowledged there were "weaknesses that exist in the current system," which had been the major cause of Ingles’ concerns. ${ }^{152}$

The state of the command had also become a concern outside of the region, culminating in a visit by Col. Eliot Cooke of the office of the Inspector General from March 4 to 29, 1943. The inspection found that there was a multiplicity of headquarters and overlapping commands, "that could only be justified by the original strategic conception of the Caribbean Defense since the strategical (sic) situation changed, a material reduction of troops and proposed installations has been effected. However, the

150. C.E. Van Hook to General Brett. Internal CDC Memorandum, January 4, 1943, SOUTHCOM Archives, “548 E.17 B110 (7),” p. 8.

151. MG H.C. Ingles to the Assistant Chief of Staff, U.S. Army. Internal CDC Memorandum, January 8, 1943, SOUTHCOM Archives, “548 E.17 B99.”

152. MG Thos T. Handy to LTG George Brett. Internal CDC Memorandum, February 27, 1943, SOUTHCOM Archives, “548 E.17 B99,” p. 15. 
Command and staffs have remained practically intact." ${ }^{\circledR 53}$ Subsequently it became an issue of how to adequately reduce not only the number of troops assigned to units under the Command, but also the number of personnel assigned to the Command itself. In other words, the headquarters itself would have to undergo reductions in forces and streamlining of separate different sub-commands for greater efficiency.

One of the first changes in the structure of the Command occurred in May 1943, when the Puerto Rico Department was changed to include the Trinidad Sector and Base Command and became the Antilles Department, thus merging three separate subcommands into one. The 6th Air Force was then split roughly in half with one portion being placed in the Antilles Department and becoming Antilles Air Command. Concurrent with this change, CDC troop strength was ordered reduced from approximately 110,000 to 90,000 by the middle of the following year. ${ }^{154}$ That the Caribbean portion of the Command's Area of Responsibility was the first to be affected by reductions was perhaps no surprise. Aside from the submarine attacks which had been largely dealt with, very little activity had occurred in the Caribbean, and though there were still fears that the Canal would present a tempting target, the originally planned regional set of Caribbean bases were never finished as there was no need for them.

In point of fact, there were important assets that needed protection in the region. The Canal itself was only one part of a larger transportation complex. Panamanian

153. Deputy Chief of Staff of the War Department to MG Virgin L. Peterson. Internal CDC Memorandum, April 3, 1943, SOUTHCOM Archives, “548 E.17 B99,” p. 9.

154. History of the CDC. Internal CDC Report, January 24, 1944, SOUTHCOM Archives, "548 E.17 B93 (1)," p.5. (Hereafter cited as History of the CDC, 1944.) 
railways were an integral part of the transportation hub formed by the Canal. As noted earlier, these railways were actually sophisticated and developed enough to completely supplant the Canal in transporting all necessary commerce and matériel, even if the Canal had been rendered inoperative (albeit at a higher cost). ${ }^{155}$ Threats to the railways then were as important to deal with as those to the Canal. It was clear that as far as protection activities, the Canal Zone and its accessways were more deserving of resources than the Caribbean. Unity of command had also never really been appropriately established over the entire Caribbean due to the difficulty in coordinating operations at such a distance from Command headquarters in Panama. ${ }^{156}$

The changes the Command was undergoing caused unity of command to suffer throughout the year. Many of the reorganizations led to confusion among the subcommands as to who was in charge of what mission. Often reorganizations sent a mixed message. For instance, a medium range radio loop station was installed at Managua airport and modified for use of heavy bombardment craft and patrols. These multiple uses suggested a need for coordination and strong unity of command within the Panama Sea Frontier. ${ }^{157}$ However a radio transmission sent instructions removing unity of command under $10^{\text {th }}$ Fleet for the Panama Sea Frontier while maintaining it everywhere else it had existed, suggesting the Panama Sea Frontier did not require such unity of

155. César A Vásquez, "Military Significance of the Panama Canal,” 43, George A. Smathers Libraries, University of Florida, 100 years of the Panama Canal: Celebrating the Centennial, 1914-2014 (2014).

156. History of the CDC, 1944, p. 9.

157. Evans, Anti-Submarine Activities. 
command. ${ }^{158}$ The amount of confusion this type of re-shuffling caused left the Command vulnerable to massive disorganization and discouraged robust activity.

At times, the relative lack of activity threatened to make the command forget its nature as a military asset. In May, 1943 Major General Glenn Edgerton, the Governor of the Canal Zone, sent a letter to General Brett requesting the relaxation of restrictions on travel of dependent family of Canal Zone personnel. The Governor's argument centered on the acknowledged acceptance that the threat to the Caribbean theater had largely dissipated. As he put it, “The military reasons for the restriction seems to the employees to be growing constantly less urgent and they now regard it as a rather arbitrary ruling, warranted perhaps, as the time it was imposed but no longer of much practical necessity.” 159 In fact, the restrictions were part of the military plan and had been enacted via official orders so they could not be easily relaxed the way a business would change a policy. The request rather demonstrated an attitude from base personnel that was remarkably detached from the usual military way of thinking.

The acknowledged need for reductions had to be tempered by the necessity to continue to operate in the missions that still remained. To this end General Brett once again found himself trying to deal with interagency resource conflicts as he had in the Pacific. Of particular note was a June 15 discussion regarding assigning “Flare Wing 3,” a fighter squadron to Panama Sea Frontier instead of having them assigned directly to the

158. BG J.E. Hull, Acting Assistant Chief of Staff to General George Brett. Internal CDC Correspondence, June 5, 1943, SOUTHCOM Archives, “548 E.17 B122.”

159. MG Glenn Edgerton, Governor, Canal Zone to General George Brett. Internal CDC Correspondence, May 24, 1943, SOUTHCOM Archives, “548 E.17 B138.” 
Navy's 10th fleet. ${ }^{160}$ With the previous reductions in air assets, Brett was anxious this unit be assigned directly to the Command due to fear that having them assigned directly to 10th Fleet would put them in the direct line of command of the Department of the Navy, possibly causing the Command to lose the ability to call on the unit in times of need. No doubt remembering the difficulty he had experienced just the previous year securing air transportation from a Navy commander when trying to transport General MacArthur to Australia, he was understandably fearful that if this unit were put directly under the Navy, the assets could be simply moved away (maybe even capriciously) on orders from $10^{\text {th }}$ Fleet without any discussions with Caribbean Defense Command.

Still, with the knowledge that reductions would continue, the Caribbean Defense Command proposed an organizational chart in August 1943 that called for a 40\% personnel reduction. Though this organizational chart was never actually approved, it became the basis for the headquarters reorganization that would later take place. Aside from force reductions, the new plan also called for streamlining special staff. ${ }^{161}$ Later that same month, the War department decided Caribbean Defense Command should prepare for further reductions and set the new troop ceiling at 75,000 to be effective July 1, 1944. ${ }^{162}$ Since the Antilles Department was at the same time reduced to Defense Category “A," indicating an area of least military concern, the Caribbean Defense

160. BG D. L. Weart, Chief of Staff Caribbean Defense Command to BG J.E. Hull, Operations Division, War Department General Staff. Internal CDC Correspondence, June 15, 1943, SOUTHCOM Archives, “548 E.17 B122."

161. Headquarters and Staff, CDC, 25.

162. History of the CDC, 1944, p. 5 
Command leadership concluded that the bulk of troop reductions should come from there. ${ }^{163}$

When the Command had first been set up, its mission had been seen as necessitating it be placed under defense category “D," the highest possible category indicating actual or impending hostilities. The stated reason for this was that there had been a real fear of sabotage, revolts, and disorder due to Axis/Japanese presence within the AOR at the beginning of the war. ${ }^{164}$ As these attacks for the most part failed to materialize, the Command's operating defense category had been progressively reduced. In a letter dated September 10 from the War Department, Brett was told that it was expected that the entire Caribbean Defense Command would undergo the same reduction in Defense Category as had been given to the Antilles Department by the middle of the following year. It said in part,

In connection with the development of overall plans for the progressive reduction of defensive installations, both in the United States and overseas, as the need for such installations decreases, the total garrison strength of the Caribbean Defense Command (exclusive of Air Transport Command activities) on 1 July 1944, will not exceed 75,200 . This strength is predicated on the reduction of the category of defense in your theater to category of defense 'A', Modified. ${ }^{165}$

By 1943, it was possible to eliminate the long distance striking force of the Caribbean Defense Command (meaning parachute troops and airborne infantry), as they had never been needed, and with the end of the war clearly in sight and with Axis

163. History of the CDC, 1944, p. 6.

164. History of the CDC, 1944, pp. 2-7.

165. U.S. War Department Office of the Adjutant General to General Brett. Internal CDC Correspondence, September 10, 1943, SOUTHCOM Archives, “548 E.17 B99,” p. 6. 
aggression in the AOR either receding or never having materialized, it did not appear they ever would be during the conflict. ${ }^{166}$

All this is not to say that the CDC was a failed command, constantly being cannibalized and under constant reduction. The Command did experience several successes under General Brett. Among the various successes that the Caribbean Defense Command was undergoing was an increased diplomatic role. This was due not only to the Command's presence in the region, but also due to General Brett's own proclivities for outreach to the local governments. Without Brett's outreach activities one could easily see a different pattern having developed where the Command was simply downsized into oblivion with little or no chance to demonstrate a value outside of its originally stated purpose. Demonstrating that a joint combatant command could be an important player in aiding diplomacy would be one of the CDC's greatest achievements.

Ironically, one of Brett's early attempts at diplomacy almost resulted in diplomatic disaster. A supposed slight almost derailed his relationship with the President of Colombia, a nation that would later go on to become an important strategic partner despite its strained history with the United States. In a hand signed letter to Undersecretary of State Sumner Welles Dated April 12, 1943 and marked "Personal and Confidential,” U. S Ambassador to Colombia Arthur Bliss Lane wrote that he had been informed that Brett had acted unprofessionally. The general was reportedly irritated by the behavior of Colombian President Alfonso López Pumarejo during his recent visit to

166. History of the CDC, 1944, p. 8. 
Colombia, where Brett allegedly behaved as if Lopez was intentionally slighting him. Lane proceeded to state, "that it is most unfortunate that an Army officer in such an important post should have such a petty attitude and should not be able to distinguish between official and personal matters.” ${ }^{167}$ The two alleged slights against Brett were that President Lopez had not met him at the airport upon his arrival, and had then kept him and his party waiting for a previously scheduled meeting. Although it is impossible to know what Brett was thinking at the time, it is easy to surmise that the two incidents had been a direct reminder of his treatment at the hands of MacArthur just the previous year, and though not hyper-sensitive like MacArthur, it must have been grating to be reminded of his humiliation in such a way.

There is no record of what guidance the embassy received back from the State Department. The matter seemed to have been handled delicately through a letter from the U.S. Embassy in Colombia dated April 28. In the letter (which was not directly written by Lane, but claimed to relay a message from him), General Brett was told of possible criticism of the United States by Colombian officials who believed the United States had shown a preference for Peru in their lend-lease shipments. This was a believable (and possibly true) claim, as inter-American competition for U.S. assistance had already begun to rear its head, and Peru and Colombia were often at odds. Brett was asked simply to write a letter to Lopez to thank him and his country both for their warm reception and

167. Arthur Bliss Lane, Ambassador to Undersecretary of State Sumner Welles. Personal Correspondence, April 12, 1943, SOUTHCOM Archives, “20111-11.” 
their cooperation in the war effort. ${ }^{168}$ Though there is no record of whether or not Brett ever learned of Lane’s original complaint, he seemed to have either suppressed the incident or chosen to retain only the positive aspects of it as on April 30 he sent the requested letter to Lopez thanking him for his "most courteous hospitality which was extended...[during his] most recent visit.” The letter, written with typical diplomatic aplomb goes on to thank Lopez for the cooperation extended by Colombia in meeting the defensive requirements set up by the Command. ${ }^{169}$ Relations seem to have improved markedly following this misunderstanding and a mere three weeks after that first disastrous meeting, General Brett was communicating with Ambassador Lane about positive progress in placing U.S. Personnel in Colombia. ${ }^{170}$

Colombia was not the only country where diplomacy was needed. Since October of 1942, the United States had been maintaining bases in the Galapagos Islands via verbal agreement with the Ecuadorian government. U.S. planners strongly desired trying to retain these bases after the war, either through a long term agreement or outright purchase, making future negotiations likely. ${ }^{171}$ Unfortunately, the ultimate fate of such

168. Edwin C. Wilson, U.S. Embassy to Colombia to General George Brett. Personal Correspondence, April 28, 1943, RG 548, Tack area 290, Row 40, Compartment 22, Box 51.

169. George Brett to Dr. Alfonso, Lopez Pumarezo, President of Colombia. Personal Correspondence, April 30, 1943, RG 548, Tack area 290, Row 40, Compartment 22, Box 51.

170. Arthur Bliss Lane, Ambassador to General George Brett. Personal Correspondence, May 6, 1943, RG 548, Tack area 290, Row 40, Compartment 22, Box 51.

171. General George Brett to Chief of Staff, War Department. Personal Correspondence, March 16, 1943, SOUTHCOM Archives, “548 E.17 B56 (2).” 
bases would be left in the hands of Brett's successor who would seriously bungle the affair (see Chapter 5) and thereby teach the command an entirely different set of lessons.

Diplomacy had not only been important in securing bases, but also in continuing to reduce the Axis threat. Throughout the war, U.S. planners had worried about the relative weaknesses in the region attracting Axis activity. As the war began to wind down, the stability of the Central American and South American governments was still a concern, though allied influence had helped. ${ }^{172}$ As the command was scaled back, it became important to maintain the stability that had been achieved, given that there would be fewer resources to deal with any new issues which may crop up. Toward the end of the war, most observers agreed that diplomacy more than military power had helped reduce Axis threats in the region. ${ }^{173}$

Brett used his position to make the Caribbean Defense Command a hub for diplomatic activity, flying extensively in the Swoose on his missions. Not only was it used by Brett himself, but it also ferried diplomats and other people of importance around the Command. According to one source, "The flight log of the Swoose records that Brett visited Miami; the island nation of Trinidad; Quito, Ecuador; San Juan, Puerto Rico; San Jose, Costa Rica; Bogotá, Colombia; Santiago, Chile; and Lima, Peru, between December 1942 and June 1943. In July 1943 Brett took famous journalist Lowell Thomas on an aerial inspection tour of the Panama Canal fortifications. According to a former Swoose

172. History of the CDC, 1944, p. 8.

173. History of the CDC, 1944, p.8. 
pilot, Brett's favorite way to close a visit was with a low, high-speed pass over the airfield on departure.” ${ }^{174}$ Nor was the Swoose Brett's only tool. He reportedly also commandeered a U.S. rescue boat squadron to host fishing parties, and spent so much money entertaining dignitaries that eventually it led to a formal inquiry regarding his spending habits. ${ }^{175}$ For better or worse, Brett set the tone for the type of outgoing diplomacy that would need to be undertaken by the command and its successor commands in dealing with the region. His affable, personable way of developing one on one relationships with foreign dignitaries is a standard that is followed to this day, and which he instinctively understood the need for.

\section{$\underline{\text { Racial Issues }}$}

Among the varied developments that the Command experienced during 1943, there is one minor one that stands out as an exceptionally disturbing. Racial issues, always a factor in dealing with Latin America, began to be looked at more carefully. The region, particularly the Pacific coast is home to a large Japanese community, and the ongoing war with Japan had already been behind one of the most shameful episodes in American history, the internment of Japanese citizens in the United States. In the CDC AOR, though not going as far, it was made clear that the number of people of Japanese descent was troubling to the Command. A restricted War Department communication dated October 14, 1943 had sought to deal with this issue via establishing clearly defined

174. Cox, Airpower Leadership, 74.

175. Cox, Airpower Leadership, 75. 
parameters on how to deal with Japanese in the region. Although acknowledging the need for maximum utilization of all available manpower in the war effort, it said, that "No person of Japanese ancestry will be employed in a plant or facility important to the war effort,” without approval from either the Japanese-American joint Board or the Provost Marshall General. Likewise, it also said that no person of Japanese descent would be "permitted to attend or be employed by an educational institution important to the war effort,” without similar approval. ${ }^{176}$

The use of Puerto Rican troops also displayed a similar attitude. Puerto Rican troops were increasingly being sought to supplant forces being removed from the Command. This unexpected side effect of the continued force reductions led to some discussion that would be termed disturbing in a modern light. Though exceptional in allowing the Command to increase its diversity while giving opportunities to minority citizens, the increased use of Puerto Rican troops exposed an attitude toward these troops that would rankle modern sensitivities. ${ }^{177}$

In March, 1943, the Command's Deputy Chief of Staff Lieutenant General McNarney and General Brett had discussed the possibility of using Puerto Rican troops in the command. A study was commissioned that proved prescient as the War Department soon set the 90,000 ceiling with the stipulation that the Caribbean Defense Command utilize 30,000 Puerto Ricans. There were several objections to the use of

176. War Department to Commanding Generals. Employment of Persons of Japanese Ancestry in Plants and Facilities Important to the War Effort. Internal War Department Communication, October 14, 1943, RG 548, Box 314, Stack 391.2, Race Policies.

177. History of the CDC, 1944, p. 1. 
Puerto Rican troops. Although all acknowledged that they were U.S. citizens, it was felt that they were lacking in "mental, tactical and technical ability" as well as in English proficiency. Despite these concerns, the Antilles department promised that they could produce more than the required amount of Puerto Rican troops at an even higher level than "continentals."

The requirements for the Puerto Rican troops were that they be at least $8^{\text {th }}$ grade graduates, speak English, be above the minimum weight and height levels, and receive a rating of Class 3 or higher on the Army General Classification Test. ${ }^{178}$ Additionally, official orders for the recruitment of Puerto Ricans requested that all such Puerto Rican troops be white. ${ }^{179}$ There were stated concerns that the fact that 30,000 of them were to be absorbed into the 90,000 troop ceiling meant that one out of three Caribbean Defense Command personnel would eventually be one of these Puerto Rican troops. ${ }^{180}$ Although the stated requirements for these troops were mostly a reiteration of basic requirements for Army personnel, the stipulation that they be of a specific height seems to have been drawn from racial stereotypes regarding the average height of Latin males. The further stipulation that they be white carried no practical advantage and could only be interpreted as racially motivated.

178. The AGCT was an early means for attempting the assessment of intelligence or other abilities. For further information, see Paul F. Ballantyne, Psychology, Society, and Ability Testing (1859-2002): Transformative Alternatives to Mental Darwinism and Interactionism, especially Chapter 4 (September 16, 2002). Accessed February 29, 2016. http://www.cyberus.ca/ pballan/C4P1.htm.

179. History of the CDC, 1944.

180. History of the CDC, 1944, p.6. 


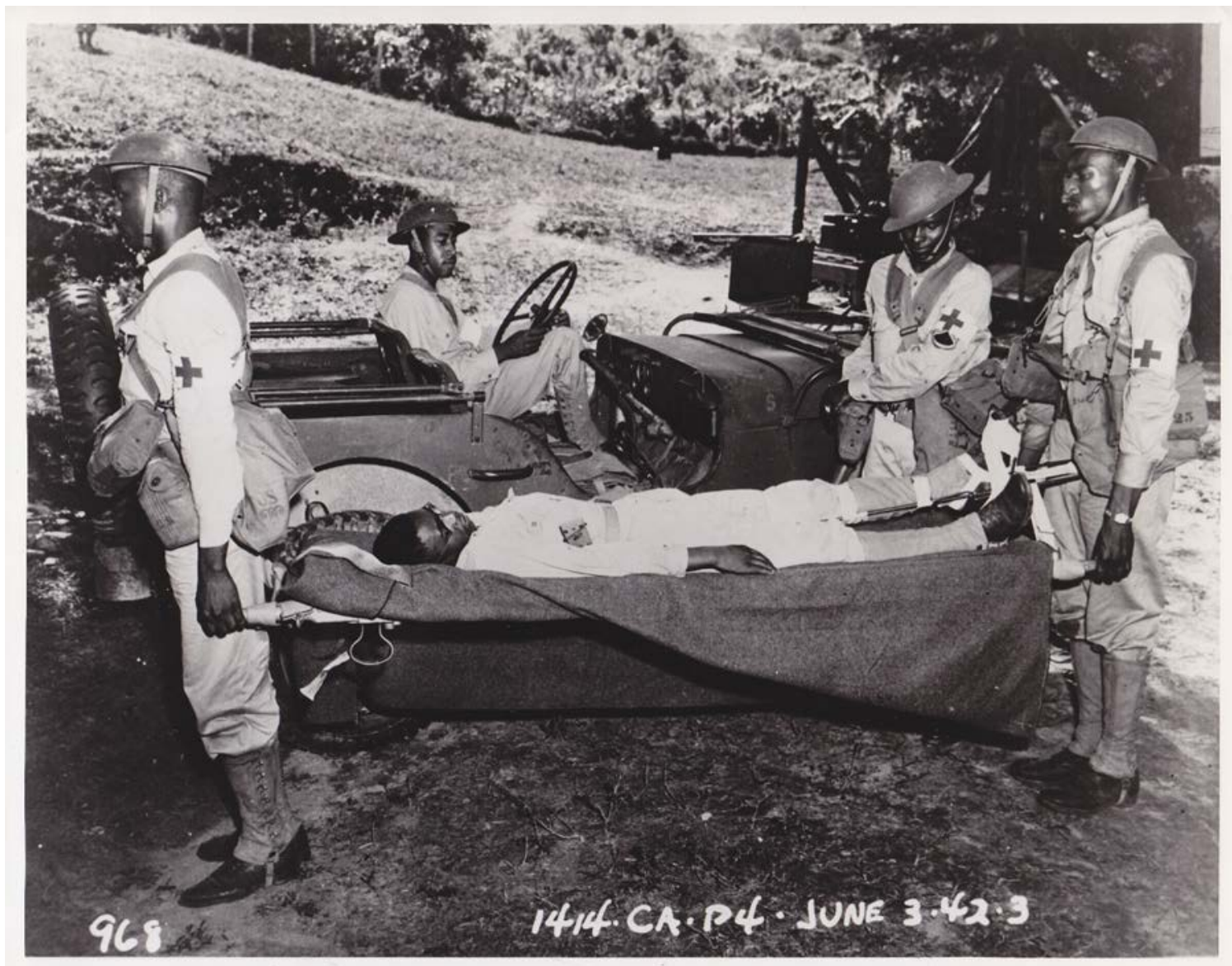

\section{FIGURE 7: Black troops in the Caribbean region in 1942.}

Source: Pictorial Archives of the United States Southern Command, SOUTHCOM Archives.

Blacks fared no better in the command, though in point of fact, there were black troops serving within the CDC, as is evidenced by an internal CDC photograph depicting them demonstrating a Jeep being used as a field ambulance somewhere in the Caribbean region in 1942 (see Figure 7). Their assigned duties, however, were very restricted. A 1947 memo reiterating racial policy drew a response that there were no "continental negroes” in the command, but that many negroes of Puerto Rican or Virgin Island origin had been scattered throughout the Antilles Department. The stated reason was that it would be "highly undesirable to utilize continental negro personnel at any place in this 
command for the reason that Latin negroes and continental negroes will not mix without resentment due to racial characteristics which are entirely different and the large differential in pay scales between military personnel and native negroes.” 181

Unfortunately, these attitudes continued to be demonstrated in the later evaluation of the Puerto Ricans once they had taken their posts. Final analysis claimed that though the first batch of Puerto Rican troops (drawn from pre-existing recruits) was more than adequate, the process established for quickly inducting and training additional troops had yielded personnel that could not adequately communicate in English and could not be assigned to very technical duties such as manning anti-aircraft batteries. They were, however, deemed particularly well suited to guard duty and similar assignments. ${ }^{182}$ Even worse, one report attributed some of their deficiencies as being due to their “...being of Latin temperament, [making it] safe to say that most Puerto Ricans are in general temperamentally unstable." ${ }^{183}$ Nevertheless, by the end of 1943, a great portion of the coast artillery in Panama was made up of Puerto Rican troops who served with honor and distinction.

Among the various objections to using Puerto Ricans in the Caribbean Defense Command that were sometimes put forth, there was perhaps one legitimate reason for doing so for reasons of diplomacy with other Caribbean nations. In a February 27

181. G.H. McManus, AGD to Adjutant General, Washington D.C. Personal Correspondence, April 18, 1947, RG 548, Box 314, folder 291.2 Race Policy.

182. History of the CDC, 1944, pp. 2-3.

183. History of the CDC, 1944, p. 7. 
communication from General Thos Handy to CDC headquarters, Handy acknowledged the Caribbean Defense Command's desire to use Puerto Rican troops in Cuba but reiterated that the State Department had emphatically stated that, "the use of Puerto Rican troops in Cuba is entirely out of the question." ${ }^{184}$ The Cubans, Handy claimed, would have objected to such troops being used in their territory pointing to possible racial animosities between the peoples of Cuba and Puerto Rico. Diplomacy demanded that the Caribbean Defense Command tread carefully in such matters, and the need to placate partner nations restricted opportunities for some troops of Latin descent.

Overall, 1943 turned out to be an eventful year for the Command. Starting off with a new Commander and a new paradigm, it ended the year following a new course and with hints of a new mission. Though the year started with the Command at its strongest, it nevertheless underwent the most dramatic reductions in its brief history and was clearly marked as not being as vital to the war as other theaters. By the end of the year, the allies had already established a pattern of continuous bombing of Berlin, and had the capability to reach any site in Europe by air. By this time, about half of Italy had already been captured, and the invasion of Normandy was already being planned out to take the rest of Europe from the north. The "Big Three" had met in December for the Tehran Conference, and were confident enough in eventual victory to begin envisioning a post-war settlement. Under such circumstances, the threat to the CDC's AOR must have seemed like a secondary consideration at best. The following year, the Command would

184. MG Thos T. Handy to LTG George Brett. Internal CDC Memorandum, February 27, 1943, SOUTHCOM Archives, “548 E.17 B99.” 
continue on its new pattern of reorganization and diplomatic outreach which would eventually lead to its transformation into a successor command. 


\section{CHAPTER 5: 1944-1947, Redefinition and Rapid Downsizing}

Toward the end of 1943, the Command had already begun functioning as a more bureaucratic entity than a purely military one. General Brett's diplomatic activities throughout the region had increased and would continue to do so throughout his tenure as Commander. The Command found itself finally stabilizing after a very rapid growth, and finally being able to take a breath now that activities looked like they would be winding down. Though the war had largely not come to the region, the war footing had still raised many issues. The necessity of having a functioning patrol program, supplying military personnel, and transporting military equipment presented difficulties. A large and active military presence normally takes a toll on a region in both demands for resources and strain on utilities. The need to keep the region alert and prepared, as well as the sheer amount of military traffic, however beneficial, was bound to cause problems ranging from restrictions on civilian activities to actual accidental damages caused by the military presence.

The latter part of 1943 through 1944 saw an increase in claims against the U.S. government from partner nations and private individuals in relation to damages to both personal property and strategic assets. Though these were often little more than nuisances to be dealt with, the Command was the main U.S. representative in the region, and the need to maintain diplomatic relations with the nations along with its actual legal responsibility in dealing with such issues led to an increase in bureaucratic activity in handling these claims. 
The claims, which ranged from mundane issues such as a military truck striking and killing someone's cow, to actual severe damages such as when a U.S. plane crashed into a private ranch house effectively destroying it, were usually dealt with in a uniquely militaristic way. Initially, the claimant was required to provide a letter in writing detailing the claim. As the claims were normally in Spanish, it had to then be translated by an official translator. An investigating officer was assigned to the case in order to collect information, as well as material evidence of the damages (in the aforementioned case even going as far as examining the braking system on the truck and profiling the military driver). Any American serviceman involved in the incident had to be deposed, and such deposition had to be presented in writing. All the information would then be examined by a Board of Officers where all aspects of the incident would be analyzed. The Board of Officers then created a written review of their findings and recommendations, including a determination of damages if any (normally a monetary amount for what was considered a fair market value of damaged property). A check would then be issued to the claimant who would sign a form accepting the payment as full restitution for their loss and indemnifying the U.S. government for any further damages in relation to that incident.

Such activity, though not extremely out of the purview of normal military protocol was nonetheless somewhat unique during a time of war, demonstrating just how removed from the actual conflict the CDC AOR had become. ${ }^{185}$ They would

185. Damages due to Military Activities, RG 548, Boxes 119-120. 
unfortunately also be an early omen of some issues that would come up in the future when dealing with the national territories of some of the partner nations in the region.

Administratively speaking, the structure of the Command had stabilized by this point and any changes to the Headquarters or any of its subordinate commands were mostly reductions. From 1944 on there were few changes or additions to the Caribbean Sea Frontier for instance, though there were many base closings and de-activations. Of the changes that did happen, most had to do with changes in command, reduction of inactivation of activities, and changes in the limits and boundaries. Issues and awkwardness with the French Antilles continued for a while longer, as the islands had established a triple détente of sorts between themselves, the Caribbean Defense Command, and the government they represented. The June 6 Normandy invasion seemed a precursor to a non-Axis aligned French government for the islands which would no longer be a potential threat. ${ }^{186}$

\section{$\underline{\text { Troop Reductions }}$}

On March 31,1944, preparations were underway to begin eliminating antiaircraft defenses in many of the areas where they had been emplaced. The designation of the Defense Category to "A" status late the previous year had meant that reductions were imminent. To this end, it was first necessary to re-define all the existing areas so they could be sorted appropriately. San Juan, Guantanamo, Trinidad, and Aruba-

186. An Administrative History of the Caribbean Sea Frontier. Internal CDC Report, 1945, RG 548, "Military Histories," 45. (Hereafter cited as Admin. History of CSF.) 
Curaçao were designated as "Important Harbors” for the purposes of Anti-Aircraft activities and theoretically would not be touched, but all other harbors were open to reductions. ${ }^{187}$ On April 22, the Secretary of the Navy commanded that, routine inshore and offshore patrol, mine sweeping and patrol craft escort of shipping in inactive threat areas be discontinued except in the case of "important harbors." 188

On May 13, the Naval Order of Battle at St. Thomas was already in the process of being inactivated. Active Naval Air Station at Jamaica, Roosevelt Roads, and Antigua were reduced in classification to Naval Auxiliary Air Fields. The Naval Air Station at St. Lucia was then placed in caretaker status. On May 16, 1944, all TAG (Trinidad, Aruba, Guantanamo) and subsidiary convoys were discontinued, and most intelligence and communications were consolidated into the $10^{\text {th }}$ Naval District. On May 29, the entire region was re-defined as being a "non-combat area." Two days after the D-Day invasion of Normandy, (June 8, 1944), Defense Category “A” was lifted altogether, and four days later, the $10^{\text {th }}$ Fleet was dissolved. On June 28, the Chief of Naval Operations directed that all lend-lease bases except Trinidad be put on caretaker status.

Overall, the lifting of wartime footing continued throughout the entire AOR for the latter half of 1944. ${ }^{189}$ On August 8, Naval Auxiliary Air Fields in British Guiana

187. Admin. History of CSF, 48

188. Admin. History of CSF, 48

189. Admin. History of CSF, 53 
were further reduced to caretaker status. On August 14, the Combat Service Support Element requested plans for complete deactivation of defenses and reduction to normal status upon cessation of hostilities in Europe from all sectors and activities. Then, on July 25, a Naval Order of Battle Guantanamo dispatch stated that the Naval Auxiliary Air Field in Jamaica was to be completely decommissioned on September 1, 1944 and to be placed in caretaker status by September 6, 1944. On August 18, reports stated that Vieques (Puerto Rico) inactivation was already in process, and scheduled to be completed by September 1, along with Roosevelt Roads. The Marine Corps Air Station at St. Thomas Virgin Islands was inactivated and put on caretaker status, and Blimp detachment at Paramaribo was decommissioned by August 13, 1944. ${ }^{190}$ Throughout these many months, the only exception to this trend in reductions occurred in late 1944, when the creation of a Military Missions Division on October 6 actually added more personnel. Otherwise, the prevailing trend was in reduction of forces throughout the entire AOR. ${ }^{191}$ The fact remained, that by VE Day (May 8, 1945), no enemy forces had threatened the area at all for over ten months. ${ }^{192}$

The most striking thing about these reductions was not that they should be undertaken, but the great amount of confidence they betrayed about the successful resolution of the war and the United States' willingness to acknowledge it throughout the region. On November 1, 1944 a training directive for 1945 flat out stated that the

190. Admin. History of CSF, 49.

191. Headquarters and Staff, CDC.

192. Admin. History of CSF, 52. 
"successful" progression of the war (a strange turn of phrase given that the war was still ongoing) had allowed a re-focusing with gradual troop reductions the past twelve months, though it did warn against complacency and claimed that the Canal Zone was still vital to the War plans. More importantly, the directive added an instruction to assist the Latin American republics in modeling their military into well-functioning units based on the U.S. model. It also emphasized the importance of maintaining high morale. ${ }^{193}$ From VE to VJ Day (September 2, 1945), reductions and deactivations continued at an even faster pace. ${ }^{194}$

\section{Enemy Submarine Threat}

The submarine threat continued to be a nuisance toward the beginning of the year, though it was already highly diminished. ${ }^{195}$ Some persistent German U-Boats had remained in the region while most had left in 1943, but their numbers and tactics were very different from those of the first bold attacks on the refinery in 1942. Throughout 1944, only two vessels were sunk as a result of enemy submarine action, and it was estimated that by this time there were only six subs in the area. The two sinkings occurred early in the year, and even the meager number of remaining enemy submarines were reported to have left by July 1944. The complete removal of the enemy submarine threat made little difference when it finally happened as even while still there,

193. Training Directive, From R.E. Doan, LTC ACG Asst. Adjutant General to HQ Caribbean Defense Command. Internal CDC Directive, November 1, 1944, RG 548, UD, Entry 5, Box 1.

194. Admin. History of CSF, 53.

195. Admin. History of CSF, 45. 
observations reported that the subs had begun behaving with remarkable caution following 1943. ${ }^{196}$ This was likely due to the successful American dealings with the nations and possessions in the Caribbean, which had effectively denied these subs any friendly ports from which to operate. Commanders of German U-Boats remaining in the area by 1944 knew that if they were damaged they would likely have to scuttle their vessel (if they even survived) and possibly be taken as war prisoners. Possibly the repercussions of having machine gunned sailors in the water in 1942 weighed heavily in their decision making. It was also possible some of them had remained in the region simply for the purpose of avoiding certain death in other theaters of the war. Whatever the case, these remaining subs had not been as bold as their predecessors, and the well running anti-sub program being promulgated by the CDC had radically decreased their windows of opportunities.

The success against the U-Boat threat which had been envisioned as being a multi-faceted undertaking was eventually dealt with by more patrols and denying enemy subs friendly bases to operate out of. One relative failure in the work of the Command was in the use of mine fields which were never particularly effective even when deployed. Port Castries Harbor in St. Lucia had been mined in March 1944, but by that time, all the other precautions had already made U-boat activity too costly to enemy

196. Admin. History of CSF, 50. 
subs. ${ }^{197}$ Minefield operations in general were of doubtful usefulness in the region due to the technological issues involved, and all were removed by October $1945 .^{198}$

\section{Change of Command}

On October 15, 1945, General Willis D. Crittenberger replaced General George Brett as CDC Commander. Crittenberger, a tank commander, was a rather unusual choice for commander of Caribbean Defense Command. As a lifelong Army officer, and a war-fighter at that, he had little experience with collaboration with naval forces except perhaps for transportation. Crittenberger had served as a tank commander of IV Corps during the war, and had seen action in Italy. ${ }^{199}$ One stroke in his favor was that his unit was unusual in that it had included not only Americans but also Brazilians and South Africans. Still, his appointment seemed to put emphasis on Army presence, and de-emphasize the importance of air power in the region. ${ }^{200}$ General Crittenberger would remain as Commander for the remainder of the Caribbean Defense Command's existence and would transition to the role of Commander of U.S. Caribbean Command once the Command was reorganized in 1947.

197. Admin. History of CSF, 51.

198. Evans, Anti-Submarine Activities, 17.

199. Special to The New York Times, Aug 7, 1980, General Willis D. Crittenberger; A Leader of Allied Forces in Italy. New York Times (1923-Current File) Retrieved from http://ezproxy.fiu.edu/login?url=http://search.proquest.com/docview/121365375?accountid=10901

200. Headquarters and Staff, CDC, 31. 


\section{Unity of Command}

The issue of unity of command continued to be a major one for the CDC even as operations drew down. Bringing about unity of command among all the disparate military forces in the region had been the original reason for the CDC's existence. It had also been a key component of war planning for the entire region. Having achieved and maintained unity of command (though the degree was debatable) was seen as one of the major accomplishments of the Command, as by the end of the war, both military planners and CDC leadership were behaving as though unity of command was now a given instead of a goal to be reached. The stability which this concept inspired was evident in the Command's ongoing communications regarding the future of the region. In early 1945, a memo from General Brett regarding Command relations for the Panama Canal Department during emergency vs peacetime periods praised the unity of command that had been achieved and assumed that it would continue in peacetime in order to help manage the various supposed installations that he imagined would continue to exist in Panama in the future. He not only praised the Command's performance through December 1944, but also strongly supported the idea of formally maintaining unity of command in peacetime as well as wartime. ${ }^{201}$ This brought with it several complications. Unity of command had been largely achieved by subordinating preexisting positions and institutions to the newly created command. Oftentimes, this had led to a disparity in ranks and confusion regarding authorities. The governor of the

201. General George Brett to Chief of Staff, U.S. Army. Internal CDC Correspondence, January 10, 1945, RG 548, UD, Entry 3, Box 90. 
Canal Zone, for instance, though still nominally in charge of the entire Canal Zone was effectively subverted in his authority by the Commander of the Caribbean Defense Command. This had already been the source of some disagreement between Brett and the War Department which had sent him a letter expressing their disagreement with the concept of subordinating the Canal Zone governor in this fashion in times of peace. ${ }^{202}$

Furthermore, there were several instances where the Commander of the Caribbean Defense Command, who was dual hatted as the Commander of Army units in the area had authority to act, but not as CDC Commander. On November 1, 1945, correspondence from the War Department to the Commanding General of the Panama Canal Department regarding unity of command made clear that the Panama Canal Department commander had control of the $15^{\text {th }}$ Naval District, but emphasized that unity of command existed by virtue of his being Panama Canal Department Commander, and not by virtue of being CDC commander. Though this may seem like a distinction without a difference, it is a very important distinction to military planners. That it had not caused major conflicts was only the case because military planners had made sure to make the CDC commander the Commander of the Panama Canal Department simultaneously. Barring any subsequent streamlining of the authorities, it was possible that future commanders may not be given the same authority to act as had the wartime commanders. Thus, unity of command was seen as a desirable though complicated quality for future planning in the region. At the very least, it would require the

202. MG Glenn Edgertton, War Department to General George Brett. Internal CDC Correspondence, March 19, 1945, RG 548, UD, Entry 3 Box 90. 
permanent re-definition of the way the Canal Zone and Canal Department were organized.

\section{Difficulties Caused by Base Closings}

The closing of military and naval bases throughout the region had reached a fever pitch toward the end of 1944 . This brought controversy, and unfortunately, it would become increasingly complicated as larger more important bases throughout the region were ordered closed. The issue of base reductions was complicated by the tenuous nature of many of the agreements that had been reached after U.S. entry into war. Upon U.S. entry into the war, many of the countries in the region had been eager to get onboard with the war effort and allowed the United States to set up bases within their territories. Though most Latin American republics had remained supportive of the United States throughout the war effort, the lack of detailed agreements regarding rights to these bases now began to cause complications.

Perceiving an ascendant and wealthy postwar United States, the Latin American nations began to see U.S. military presence within their borders in a different light. Several regime changes had taken place throughout the region leaving more populist administrations less inclined to favor U.S. presence in power. The work of the CDC in handling such issues would be a precursor to the role that its successor commands and future regional combatant commands would play in the postwar world. In particular, the experiences of the CDC were a warning of the dangers involved in dealing with partner 
nations and with demands from Washington, especially when they may be at cross purposes.

Of particular note was a very badly handled situation involving Ecuador. Following a change in the ruling party in Ecuador from the one that had agreed to grant the U.S. bases in the Galapagos to a more populist, nationalistic government that did not share the same inclinations, the Ecuadorian National Assembly had resolved that their national interests required the United States to leave Ecuadorian territory after the war. ${ }^{203}$ On November 20, 1945, the government of Ecuador asked the United States to evacuate the base that had been established at Salinas. Though U.S. planners had no objection to evacuating this base, they were eager to acquire a 99 year lease on existing bases in the Galapagos Islands which were seen as necessary for the future defense of the region. General Crittenberger rightly assumed that U.S. acquiescence to Ecuadorian demands in Salinas would likely play a part in any future lease negotiations and adopted a liberal position on the disposition of U.S. equipment there. With the support of U.S. officials, the Caribbean Defense Command declared nearly all U.S. gear at Salinas to be "surplus property" which was then transferred to the Ecuadorian armed forces, and the base was handed over in a ceremony in early February 1946. The government of Ecuador as well as the Ecuadorian press were impressed with the U.S. handling of the

203. U.S. BASES AFTER WAR OPPOSED BY ECUADOR, Dec 30, 1944. New York Times (1923Current File) Retrieved from http://ezproxy.fiu.edu/login?url=http://search.proquest.com/docview/106929085?accountid=10901. 
handover, noting the United States had met and exceeded the terms of the agreements. This positively impacted U.S. relations with Ecuador for a time. ${ }^{204}$

Problems arose later when trying to negotiate for the Galapagos bases. Initial negotiations in 1944 had centered around the U.S. granting Ecuador several loans for improvements. ${ }^{205}$ The Ecuadorian government had been reluctant to sign long-term leases, and had publicly demanded \$20 million in exchange for such bases. Having publicly stated their demands, they saw themselves as unable to alter them lest they lose face internationally. U.S. planners on the other hand considered the continued U.S. presence as beneficial to Ecuador and felt the bases should simply be seen as Ecuador's contribution to regional defense. They also rightly feared that the public knowledge of having paid such an exorbitant amount set a bad precedent which would see other nations following suit increasing the costs to the United States exponentially. The impasse eventually led the Ecuadorian government to simply request that U.S. forces leave the islands.

At this point, the State Department expressed the desire not to act in any way that would give the Ecuadorians reason to believe the United States was acting in bad faith in handing over the base which they felt may complicate future relations or negotiations. General Crittenberger, however, acting on the fact that there was no

204. Bradley Lynn Coleman, Leaving Ecuador. Internal U.S. Southern Command Report, December 5, 2008, SOUTHCOM Archives.

205. U.S., ECUADOR PLAN PACT, Dec. 21, 1944. New York Times (1923-Current File) Retrieved from http://ezproxy.fiu.edu/login?url=http://search.proquest.com/docview/106907566?accountid=10901. 
formal agreement governing U.S. access to the bases, took the position that he had no authority to leave any material behind. The U.S. military began removing all usable equipment, dismantling the base, and even destroying any equipment that could not be easily transported back to the Canal Zone. Some equipment was also dumped into the sea. The reasoning was that if there was the possibility of a hostile power ever taking the bases, it was best to leave them inoperable. As a former tank commander, General Crittenberger was well versed in military strategy. His reasoning in this instance followed sound military doctrine, and was actually practiced by the British early in the war when they destroyed the French fleet at Mers El Khabr after France's capitulation to Nazi Germany. ${ }^{206}$ Diplomatically speaking however, this was a disastrous move to both the British, whose relationship with France briefly deteriorated, and to the Americans in their hopes for further relations with Ecuador.

Later, when the Ecuadorian government decided to re-open negotiations, the CDC ordered the deconstruction of the facilities to stop, and attempted to put the base in “presentable” condition for a handover ceremony. They also stationed a small number of technicians to help the Ecuadorians run the base following the handover. This was followed by a series of miscommunications over the state of the base where CDC personnel were reluctant to let on that it had been partially dismantled. Unfortunately

206. Auphan, and Jacques Mordal, The French Navy in World War II (Annapolis, MD: United States Naval Institute, 1959). 
the damage was done, and the condition of the base shocked the Ecuadorians once they saw it, especially in comparison to the condition of the Salinas base at handover.

This incident had the ultimate effect of damaging base negotiations and tarnishing for the foreseeable future the military to military relationship that had been built up between the two countries. It also amplified any future dissatisfaction with the Truman administration's lack of assistance to Ecuador as being driven by resentment. The technicians remaining on the base were a further source of resentment as it seemed that aside from wrecking the base, the United States was also refusing to vacate entirely. Worsening the problem, when finally removing these technicians, the United States took with it several water barges and equipment without which the Ecuadorians were unable to maintain the base leading them to eventually close it down for good. The whole event soured diplomatic relations between the two countries for the next decade, and served as a warning of the necessity to deal with matters not only through a military mindset, but also a diplomatic one.

\section{Increasing Diplomacy and Evolution into Caribbean Command}

Fortunately, not all relations went as badly as the Galapagos handover. The records of the CDC demonstrate that General Brett’s and later General Crittenberger’s time was increasingly dedicated to attending to international conferences and meetings. General Brett's aforementioned gregarious nature had made inroads with much of the leadership of the AOR, and though the stern Crittenberger did not share Brett's jocular personality, it had been clear to him from the moment he had been sent that he was not 
going to be leading a war fighting command. In fact, he later commented that the major mission of the command was to help train the militaries of South America in U.S. style of warfighting. ${ }^{207}$

At the height of World War II, U.S. military planners had assigned 135,000 uniformed personnel to duty stations in Latin America and the Caribbean.

Approximately half of those forces had been under the direct control of the U.S. Caribbean Defense Command, and many of the rest were under the command of one of its subordinate commands. ${ }^{208}$ After May 1945, the CDC became a major training and staging command for the retraining and deployment of Army troop units released from Europe for combat duty in the Pacific, then in late July 1945, there was one final reorganization of the CDC headquarters. ${ }^{209}$ The Command would continue under this new organizational plan until its demise.

In 1947, U.S. strategists adopted a national security plan that transformed the wartime headquarters into the U.S. Caribbean Command. In addition to defending the Panama Canal, it assumed broad responsibilities for inter-American security cooperation in Central and South America. ${ }^{210}$ In September 1947, when the Army Air

207. Willis D. Crittenberger, interview by Hardy Burt and William Bradford Huie, Columbia Broadcasting System (CBS), 1953, http://www.aspresolver.com/aspresolver.asp?AHIV;777338.

208. Cesar Vasquez, et al., Crisis, Transformation, and Renewal: Historical Review of the Tenure of Douglas Fraser (USAF) as Commander, U.S. Southern Command, June 2009-November 2012. Internal U.S. Southern Command Report, July 2014, p. 8, SOUTHCOM Archives.

209. Headquarters and Staff, CDC, 29.

210. Vasquez, et al., Crisis, Transformation, and Renewal, 8. 
Forces were separated from the Army, the ground and service organization in the Caribbean was renamed the United States Army, Caribbean. ${ }^{211}$ Communications with the War Department reiterated that an Army officer would be in charge of Panama Canal Operations and Canal Zone, while the Canal Zone governor would continue to be subject to this Army officer. ${ }^{212}$

In November of 1947, the Caribbean Defense Command was formally renamed the United States Caribbean Command, and was reorganized with new goals and responsibilities. ${ }^{213}$ General Crittenberger remained as Commander of the Caribbean Command thereby becoming its first commander. More important than the simple name change to Caribbean Command was the major change in mission set that went along with it. What would eventually become a framework for a post-war hemispheric security system had begun to take shape throughout the mid-1940s through the use of international cooperation and multinational institutions. The Pan American Union had begun the process of establishing norms in security cooperation which would ultimately lead to the Rio Pact of 1947. This declared a mutual security zone in the region holding that an attack by any other member would result in defensive action by all. ${ }^{214}$ These security norms were then continued by the Pan American Union's successor, the

211. Introduction to Records Group 548, RG 548, Decimals Finding Aid.

212. Major General J.L. Homer to Commanding General Panama Canal Department. Internal CDC Memorandum, November 1, 1945, RG 548, UD, Entry 3, Box 90.

213. Watson, Combatant Commands, 88.

214. Pan American Union, Inter-American Treaty of Reciprocal Assistance: signed at the Inter-American Conference for the Maintenance of Continental Peace and Security, Rio de Janeiro, September 2, 1947. 
Organization of American States. The emergence of the Cold War (1947-1991) put the United States in a more agreeable mood to continue the existence of a singular command to oversee the security of the region. This command, however, would not be dedicated to defending against a possible physical attack, but to fighting growing communist influence throughout the region. This would require not only a military presence, but also diplomatic activity, military training, humanitarian assistance and disaster relief, and an organized program of military training to bring the armed forces of the nations in the region in line with U.S. military norms, and to encourage military to military cooperation. The United States Caribbean Command, or CARIBCOM, is considered a direct successor to U.S. Caribbean Defense Command and as such serves as a link in an uninterrupted chain tying CDC to the current U.S. Southern Command which succeeded it in 1963 . The reorganization however, meant that the history of the Caribbean Command started in 1947 leaving the CDC's history, and more importantly many of its vital records, as a separate entity entirely. The important role that was played by CDC in the creation of a series of regionally based combatant commands was thus not evident for another generation, though its influence was always present. 


\section{CONCLUSION}

In 1947, when the new national security plan transformed the CDC into the U.S. Caribbean Command (CARIBCOM) it gave the command broad responsibilities for inter-American security cooperation in Central and South America. During the 1950s, through a series of AOR reductions, defense officials removed the Caribbean basin from the U.S. Caribbean Command's area of responsibility. In the event of a global war with the communist powers, they reasoned, U.S. Atlantic Command, based in Norfolk, Virginia, needed the Caribbean basin to conduct hemispheric antisubmarine operations. By 1960, the U.S. Caribbean Command was not engaged in the Caribbean and thus carried a name that incorrectly described its geographic responsibilities in Central and South America. The John F. Kennedy administration changed the name to U.S. Southern Command on June 6, 1963. ${ }^{215}$ Thus, current U.S. Southern Command tradition lists 1963 as the date of its founding.

During the 1960s, U.S. Southern Command's primary mission involved defending the Panama Canal, contingency planning for Cold War activities, and the administration of the U.S. foreign military assistance program in Central and South America. In particular, SOUTHCOM and partner nation personnel undertook civic-action projects to accelerate regional development. Yet, following the Vietnam War, the Joint Chiefs of Staff recommended disestablishing the command to trim the U.S. military presence

215. Vasquez, et al., Crisis, Transformation and Renewal. p 8. 
abroad. For political reasons, the command narrowly survived, albeit with even further reduced responsibilities and resources.

In the 1980s, internal conflicts in Central America, and elsewhere rekindled U.S. military interest in the region, causing the Ronald W. Reagan administration to revitalize SOUTHCOM. The need to fight against the growing communist threat made Southern Command relative again. After the end of the Cold War, Southern Command, like other U.S. military organizations, entered a period of dramatic change. SOUTHCOM eventually embraced counterdrug operations, re-expanded its area of geographic focus to once again include the Caribbean, and enhanced its capacity for humanitarian missions. Then in 1997, in anticipation of the Panama Canal Zone’s handover to Panama in line with the Carter-Torijos treaties, SOUTHCOM moved to Miami, Florida placing it for the first time within the continental United States. ${ }^{216}$ By this time, air travel and communications technology had largely negated the need to keep the command in Panama to deal with the governments of the region, and Miami had become an important international hub and venue which made the move all the more logical. Few people, however, realize that the existence of Southern Command as well as that of all other regional combatant commands can be traced directly to the CDC, headquartered in Quarry Heights, Panama. Interestingly after all the contractions and expansions in the Caribbean Command's and later Southern Command's AOR's, the present SOUTHCOM AOR is back to being largely that which existed for the Caribbean Defense Command with the only major difference being the exclusion of Cuba.

216. Vasquez, et al. Crisis, Transformation and Renewal, 8. 


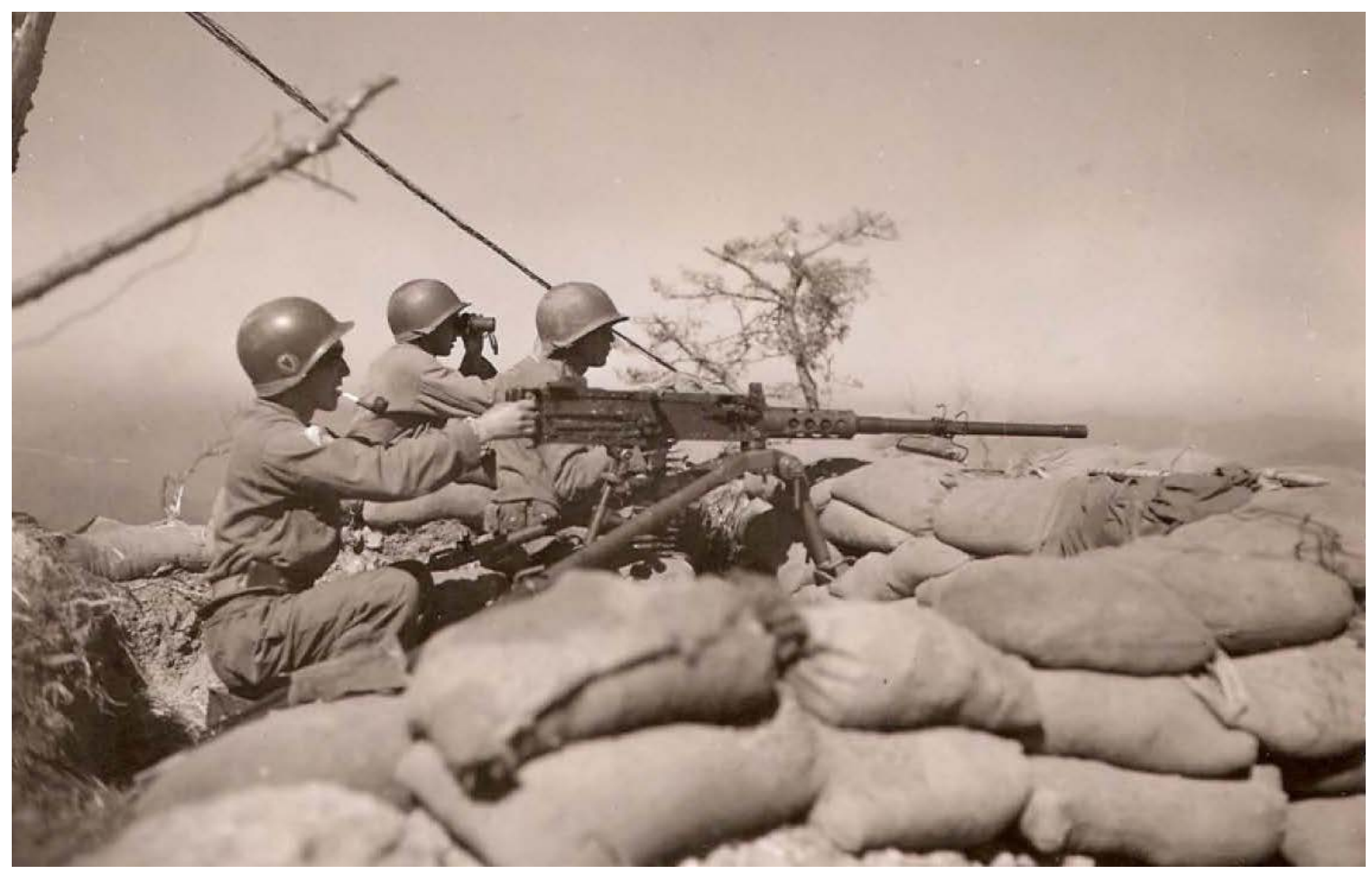

FIGURE 8: Colombian troops manning a machine gun during Korean conflict. Source: U.S. Southern Command Pictorial History 2010, SOUTHCOM Archives.

Figure 8 was used in a SOUTHCOM pictorial history prepared in 2010 to celebrate the move to its new headquarters in the Doral section of Miami, Florida. It depicts three men in military uniform manning a large machine gun emplacement. One of the soldiers is aiming the rifle while the other two look forward, one with the use of binoculars. It is an American .50-caliber machine gun, and the soldiers are wearing U.S. issue steel pot helmets and what appear to be American uniforms. The soldiers' complexions seem dark, but it is not easily discernable if this is simply because of the severe shadow their helmets cast or that they are tanned from being out in the sun while on duty. For all appearances, this could be a depiction of American soldiers at an American position. The picture, however, depicts Colombian soldiers while on duty in October 1951 during the Korean War. The fact that the soldiers are outfitted with U.S. 
issue kit including uniform and weapons is a testament to the success of U.S. engagement with Colombia and by extension, the region. It was also indicative of one of the major reasons this type of engagement was necessary during the Cold War.

Military relations with the nations in Latin America were not only designed to aid the United States in fighting counterinsurgency operations, but also to bring these nations closer to the military and later diplomatic orbit of the United States. In some cases, this proved disastrous, as one well known attempt at military training, the School of the Americas, produced highly questionable results in training partner nation personnel who would later be accused of committing human rights violations, necessitating the complete abolishment of the school. Still, military-to-military relations in the region helped facilitate diplomatic relations in other ways. Freely provided military training would potentially lead to sales of military equipment to partner nations. The sale of military equipment would then introduce these nations to an entire ecosystem of U.S. made matériel and U.S. training for equipment maintenance and spare parts. Even if this did not lead to active alliances, it would deny the Soviet Union a toehold into increased ties with these countries’ militaries.

More importantly, military-to-military relations would carry with them interpersonal relations with personnel from the region. Much as General Brett instinctively understood, personal relations with the region were a necessity which could not be ignored. Additionally, this type of engagement could not be limited to simply military relations, but diplomacy would have to be a major part of the work being done. As General Crittenberger sadly discovered in the Command's disastrous handover of the 
Galapagos bases to Ecuador, dealing with the military in the region could not simply take into consideration military doctrine, but also carry a view toward improved relations with the region. CARIBCOM and SOUTHCOM also found more kinetic ways to remain engaged with the nations in their AORs. From 1947-1998 these two commands participated in sixty-five Disaster Relief missions responding to hurricanes, earthquakes, landslides, flooding events, and volcano eruptions throughout the AOR. ${ }^{217}$ Disaster relief had started as a tertiary mission of these commands but came to be one of the major missions, and remains so to the present day. The diplomatic consequences of being the partner of choice or the first source of assistance in the region are self-evident.

The CDC set the precedent for all these activities, and though existing for a mere six years, it left a lasting legacy which can be felt to this day. By successfully maintaining control of U.S. military assets in the region during World War II it demonstrated that a joint command, consisting of Army, Army Air Corps, and Navy units could indeed work under the right leadership and structure. By successfully dispelling the Axis threat, a venture that required ample assistance from the other nations in the region, it demonstrated the United States' willingness to serve as a partner and thereby served as a tool for diplomacy. As it evolved, it shifted its focus more toward humanitarian assistance and military training to help bring the nations of the AOR in line with the U.S. military. By the end, as its military resources waned, but its engagements with the region continued, it began to act more as a partner than a simply military

217. J.A. Pitts, Historical Review, Disaster Relief Operations in the Southern Theater, Internal USSOUTHCOM Report, April 14, 2000, SOUTHCOM Archives. 
organization. Though lacking any actual State Department contingent like Southern Command currently has, the CDC was forced to utilize available resources of the U.S. government to try to maintain these partnerships, and toward the end of the war, these included activities such as disaster relief and similar non-traditional missions. The CDC never fully achieved embracing a whole of government approach, but in fairness, the CDC never had to deal with a competing potential partner to the degree its successors would when trying to give the nations of the region an alternative to the growing Soviet influence. However, it is clear that the active open engagement with the region in nontraditional military activities were a tepid early step toward what would evolve into a whole of government approach.

That the CDC never really achieved all its stated goals was not so much a failure by the Command itself, but rather a consequence of the changing facts on the ground. That several of the planned bases the Command was charged with building and maintaining were scrapped before even being completed meant that it would never be able to accomplish its original mission. The original mission, however, had been predicated on responding to events that never occurred, and the fact that the Command was able to keep some of these from occurring was another testament to its importance. The fact that the Caribbean theater never developed into an active theater of the war meant that the CDC would not be needed for the purposes it was originally envisioned. It found other outlets for aiding the war effort, however, and non-kinetic as it may seem, denying the enemy safe ports or friendly waters through the use of diplomacy and cooperation was an actual accomplishment that yielded very real wartime benefits. In the end, the progress of the war kept the Command from reaching its stated goals, but did not 
prevent it from demonstrating its usefulness. The relations with the region that the CDC formed later lent themselves to greater military cooperation, which in turn came to be part of U.S. policy in waging the Cold War.

Neither the later developments in the SOUTHCOM AOR, nor the establishment of regionally based combatant commands that now encompass the entire world would have been possible without the groundwork first set up by the Caribbean Defense Command. The fact that the CDC functioned, survived, carried out most of its mission, and was able to evolve into something new, encompassing non-traditional military aspects, helped set the stage for the military reforms which established the current COCOM system. Thus, the increased diplomacy which the current COCOM system has facilitated were actually a continuation of the work first attempted by the Caribbean Defense Command. It is clear then, that this process did not begin in a vacuum with the adoption of the 1947 Unified Command Plan, as Watson has suggested, but rather in 1941 with the first moves toward the creation of the CDC. When looking at the history of joint combatant commands then, it is necessary to include the history of the Caribbean Defense Command at the front. 


\section{EPILOGUE}

Research into the Caribbean Defense Command is far from complete. Its records were eventually packaged and sent to the United States National Archives where they were kept until being moved to the new National Archives facility in Suitland, Maryland near the campus of the University of Maryland. They have remained there largely undisturbed. An adequate index does not exist for the entire collection, though one section does have a finding aid that is over 300 pages long. There are several other sections of approximately the same size or larger that have not been adequately itemized. During the summers of 2008-2012, under the leadership of SOUTHCOM Command Historian Dr. Bradley Coleman, several summer interns began the process of digitizing parts of these documents for posterity. Their work has only scratched the surface. Even then, as the knowledge of the CDC’s activities has increased within United States Southern Command, much of the importance of the CDC's work has started to become part of SOUTHCOM’s institutional memory.

Opportunities for future research on this subject abound. Despite the continued efforts of the U.S. Southern Command History Department, Record Group 548 remains only lightly touched. The amount of sheer data that can be found within the boxes of this collection is such that Dr. Coleman once jokingly referred to each container as being a “dissertation in a box.”218 Hyperbole aside, any sample box from the collection has the potential to reveal areas of study that had not even been perceived of before. As

218. Bradley Lynn Coleman, Ph.D. Director, John A Adams Center, Virginia Military Institute, in personal communication with the author, February 19, 2016. 
historians look more into this untapped resource, surely the significance of the CDC will be further illuminated.

There are countless topics which could be further examined. Each one of the CDC's subordinate commands could have a detailed history written on its own administrative and war-fighting struggles. The history of the relations between the CDC and the Panamanian government deserve a far more detailed look than this dissertation has been able to include. Likewise, the relations between the CDC and each one of the nations in the region were extremely varied, but all helped to shape the postwar makeup of the region, and all deserve their own examination. The role that minorities played in the CDC is another issue that only received a passing mention here and deserves to be further examined. The role of women in the Command is also ripe with opportunities for further research. The CDC's efforts to handle enemy aliens and possible fifth column or insurgent groups could also fill many volumes. For now, many of these unanswered questions as well as countless others one cannot even begin to recognize will remain in the purview of future research. 


\section{BIBLIOGRAPHY}

Books

Aron, Robert. The Vichy Regime, 1940-44. Boston: Beacon Press, 1969.

Atkins, G. Pope, and Larman C. Wilson. The Dominican Republic and the United States: from Imperialism to Transnationalism. Athens, GA: University of Georgia Press, 1998.

Ballantyne, Paul F. Psychology, Society, and Ability Testing (1859-2002):

Transformative Alternatives to Mental Darwinism and Interactionism. September 16, 2002. Accessed February 28, 2016. http://www.cyberus.ca/ pballan/C4P1.htm.

Bemis, Samuel Flagg. The Latin American Policy of the United States. New York: Harcourt, Brace and Co., 1943.

Benjamin, Jules R. The United States and the Origins of the Cuban Revolution: An Empire of Liberty in an Age of National Liberation. Princeton, NJ: Princeton University Press, 1990.

Boucher, Philip P. Cannibal Encounters: Europeans and Island Caribs, 1492-1763. Baltimore, MD: Johns Hopkins University Press, 1992.

Braudel, Fernand. The Mediterranean and the Mediterranean World in the Age of Philip II. New York: Harper \& Row, 1972.

Brown, Gordon S. Toussaint's Clause: The Founding Fathers and the Haitian Revolution. Jackson, MS: University Press of Mississippi, 2005.

Brownstein, Herbert S. The Swoose: Odyssey of a B-17. Washington, DC: Smithsonian Institution Press, 1993.

Bushnell, David. The Making of Modern Colombia: A Nation in Spite of Itself. Berkeley, CA: Univ. of California Press, 1993.

Cardoso, Fernando Henrique. Dependency Revisited. Austin, TX: University of Texas Press, 1973.

Clayton, Lawrence A. Peru and the United States: The Condor and the Eagle. Athens, GA: University of Georgia Press, 1999. 
Coleman, Bradley L. Colombia and the United States: The Making of an Inter-American Alliance, 1939-1960. Kent, Ohio: Kent State University Press, 2008.

Conniff, Michael L. Panama and the United States: The Forced Alliance. Athens, GA: University of Georgia Press, 2001.

Cox, Douglas. Airpower Leadership on the Front Line: Lt Gen George H. Brett and Combat Command. Montgomery, AL: Air University Press, 2006.

Crosby, Alfred W. The Columbian Exchange: Biological and Cultural Consequences of 1492. Westport, CT: Greenwood Publishing, 1972.

Ewell, Judith. Venezuela and the United States: From Monroe's Hemisphere to Petroleum's Empire. Athens, GA: University of Georgia Press, 1996.

Ferrer, Ada. Insurgent Cuba: Race, Nation, and Revolution, 1868-1898. Chapel Hill, NC: University of North Carolina Press, 1999.

Field, Thomas C. From Development to Dictatorship: Bolivia and the Alliance for Progress in the Kennedy Era. Ithaca NY: Cornell University Press, 2014.

Gootenberg, Paul. Andean Cocaine: The Making of a Global Drug. Chapel Hill, NC: University of North Carolina Press, 2008.

Green, David. The Containment of Latin America: A History of the Myths and Realities of the Good Neighbor Policy. Chicago: Quadrangle Books, 1971.

Hersh, Seymour M. The Price of Power: Kissinger in the Nixon White House. New York: Summit Books, 1983.

Hoffman, Jon T. The Panama Canal: An Army's Enterprise. Washington, D.C.: Center of Military History, United States Army, 2009. Accessed February 28, 2014. http://catalog.hathitrust.org/api/volumes/oclc/469627028.html.

Hulme, Peter. Colonial Encounters: Europe and the Native Caribbean, 1492-1797. London: Routledge Press, 1992.

Hulme, Peter, and Neil L. Whitehead. Wild Majesty: Encounters with Caribs from Columbus to the Present Day, An Anthology. Oxford, UK: Clarendon Press, 1992. 
Humphreys, R. A. Latin America and the Second World War. London: University of London Press, 1981.

Knight, Franklin W. The Caribbean: The Genesis of a Fragmented Nationalism. New York: Oxford University Press, 1990.

LaFeber, Walter. The New Empire: An Interpretation of American Expansion,18601898. Ithaca, NY: Cornell University Press, 1963.

Langley, Lester D. America and the Americas: The United States in the Western Hemisphere. Athens, GA: University of Georgia Press, 1989. . The Americas in the Age of Revolution, 1750-1850. New Haven, CT: Yale University Press, 1996.

Lehman, Kenneth Duane. Bolivia and the United States: A Limited Partnership. Athens, GA: University of Georgia Press, 1999.

Lowenthal, Abraham F. Partners in Conflict: The United States and Latin America. Baltimore, MD: Johns Hopkins University Press, 1987.

Maurer, Noel, and Carlos Yu, C. The Big Ditch: How America Took, Built, Ran, and Ultimately Gave Away the Panama Canal. Princeton, NJ: Princeton University Press, 2011.

Moreno Fraginals, Manuel. The Sugar Mill: The Socioeconomic Complex of Sugar in Cuba, 1760-1860. New York: Monthly Review Press, 1976.

Nelson-Pallmeyer, Jack. School of Assassins: The Case for Closing the School of the Americas and for Fundamentally Changing U.S. Foreign Policy. Maryknoll, NY: Orbis Books, 1997.

Neptune, Harvey R. Caliban and the Yankees: Trinidad and the United States Occupation. Chapel Hill, NC: University of North Carolina Press, 2007.

Parker, Jason C. Brother's Keeper: The United States, Race, and Empire in the British Caribbean, 1937-1962. Oxford, UK: Oxford University Press, 2008.

Pérez-Stable, Marifeli. The Cuban Revolution: Origins, Course, and Legacy. New York: Oxford University Press, 1999.

Pike, Fredrick B. The United States and the Andean Republics: Peru, Bolivia, and Ecuador. Cambridge, MA: Harvard University Press, 1977. 
Pineo, Ronn F. Ecuador and the United States: Useful Strangers. Athens, GA: University of Georgia Press, 2007.

Posada-Carbó, Eduardo. The Colombian Caribbean: a Regional History, 1870-1950. Oxford, UK: Clarendon Press, 1996.

Rabe, Stephen G. Eisenhower and Latin America: The Foreign Policy of Anticommunism. Chapel Hill, NC: University of North Carolina Press, 1988.

Randall, Stephen J. Colombia and the United States: Hegemony and Interdependence. Athens, GA: University of Georgia Press, 1992.

Renda, Mary A. Taking Haiti: Military Occupation and the Culture of U.S. Imperialism, 1915-1940. Chapel Hill, NC: University of North Carolina Press, 2001.

Rogoziński, Jan. A Brief History of the Caribbean: From the Arawak and the Carib to the Present. New York: Penguin Putnam, 1999.

Roorda, Eric. The Dictator Next Door: The Good Neighbor Policy and the Trujillo Regime in the Dominican Republic, 1930-1945. Durham, NC: Duke University Press, 1998.

Sater, William F. 1990. Chile and the United States: Empires in Conflict. Athens, GA: University of Georgia Press, 1990.

Schoultz, Lars. Beneath the United States: A History of United States Policy Toward Latin America. Cambridge, MA: Harvard University Press, 1998.

Schulzinger, Robert D. Henry Kissinger: Doctor of Diplomacy. New York: Columbia University Press, 1989.

Sigmund, Paul E. The United States and Democracy in Chile. Baltimore, MD: Johns Hopkins University Press, 1993.

Smith, Robert Freeman. The Caribbean World and the United States: Mixing Rum and Coca-Cola. New York: Twayne Publishers, 1994.

United States. Quadrennial Defense Review Report. Washington, DC: Dept. of Defense, 2001. http://purl.access.gpo.gov/GPO/LPS18834.

Watson, Cynthia A. Combatant Commands: Origins, Structure, and Engagements. Westport, CT: Praeger Security International, 2011. 
Williams, Eric. From Columbus to Castro: The History of the Caribbean, 1492-1969. New York: Harper \& Row, 1971.

Articles

Friedman, Max Paul. "Retiring Puppets, Bringing Latin America Back in: Recent Scholarship on United States-Latin American Relations.” Diplomatic History 27.5 (Nov. 2003): p621-636.

Gilderhus, Mark T. "An Emerging Synthesis? US-Latin American Relations since the Second World War.” Diplomatic History 16 (Summer 1992): 429-452.

Lowenthal, Abraham F. "United States Policy toward Latin America: Liberal, Radical, and Bureaucratic Perspectives.” Latin American Research Review 8 (Fall 1973): 3-25.

Pan American Union Inter-American Conference for the Maintenance of Continental Peace and Security. Inter-American Treaty of Reciprocal Assistance, Rio de Janeiro, (September 2, 1947).

Archival Sources

SOUTHCOM Archives, Miami, Florida.

Record Group 548, U.S. National Archives II, Suitland, Maryland.

Record Group 38, U.S. National Archives, Washington, D.C. 
VITA

CESAR A. VASQUEZ

Born, Lima, Perú

1989

Outstanding Accomplishment in History Award

Hialeah High School

Hialeah, Florida

1993

Member Phi Alpha Theta International History Honor Society

1993

B.A., History/Political Science

Florida International University

Miami, Florida

1998

M.A. History

Florida International University

Miami, Florida

2008

Member Golden Key International Honor Society

2009-2015

Historian

United States Southern Command

Miami, Florida

2014-2016

Doctoral Candidate

Florida International University

Miami, Florida

2016

Digital Teaching Assistant-History Department

Florida International University

Miami, Florida

\section{PUBLICATIONS}

Leonard, Thomas M., Jürgen Buchenau, Kyle Longley, and Graeme S. Mount. Sendero Luminoso/Shining Path Guerilla Movement in Peru (2012). Encyclopedia of U.S.-Latin American Relations. Thousand Oaks, Calif: SAGE/CQ Press.

Vasquez, C.A. (2014). Military Significance of the Panama Canal, P 46-55. George A. Smathers Libraries. (2014). 100 years of the Panama Canal: Celebrating the Centennial 1914-2014.

Online version: http://ufdc.ufl.edu/IR00003853/00001/pageturner\#page/49 